
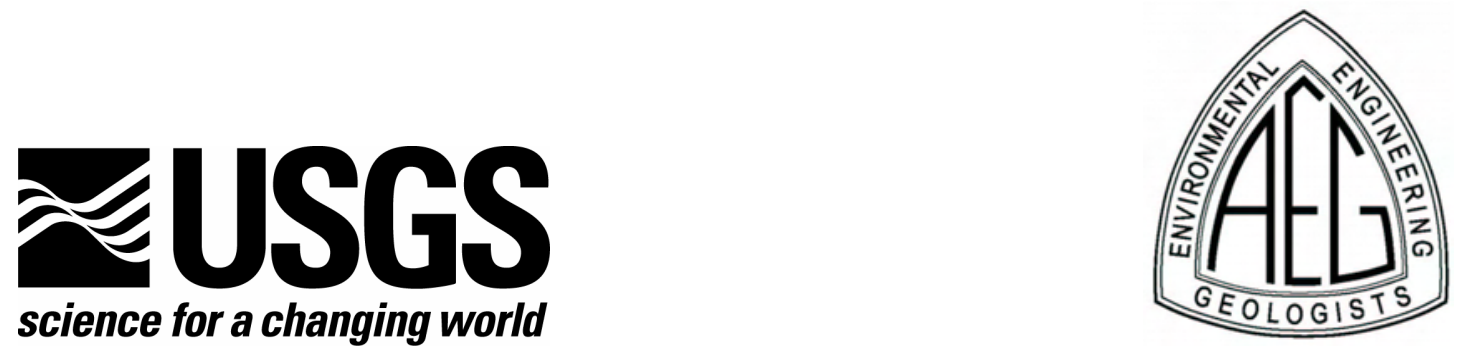

Prepared in cooperation with the Association of Environmental \& Engineering Geologists

\title{
Mass Wasting Following the 2002 Missionary Ridge Fire near Durango, Colorado, a Field Trip Guidebook
}

By Jeffrey A. Coe (editor), Erica R. Bigio, Robert W. Blair, Jr., Michael Burke, Susan H. Cannon, Victor G. deWolfe, John Ey, Joseph E. Gartner, Mary L. Gillam, N.D. (Butch) Knowlton, Paul M. Santi, and William H. Schulz

Open File Report 2007-1289

Association of Environmental \& Engineering Geologists Special Publication No. 20

U.S. Department of the Interior

U.S. Geological Survey 


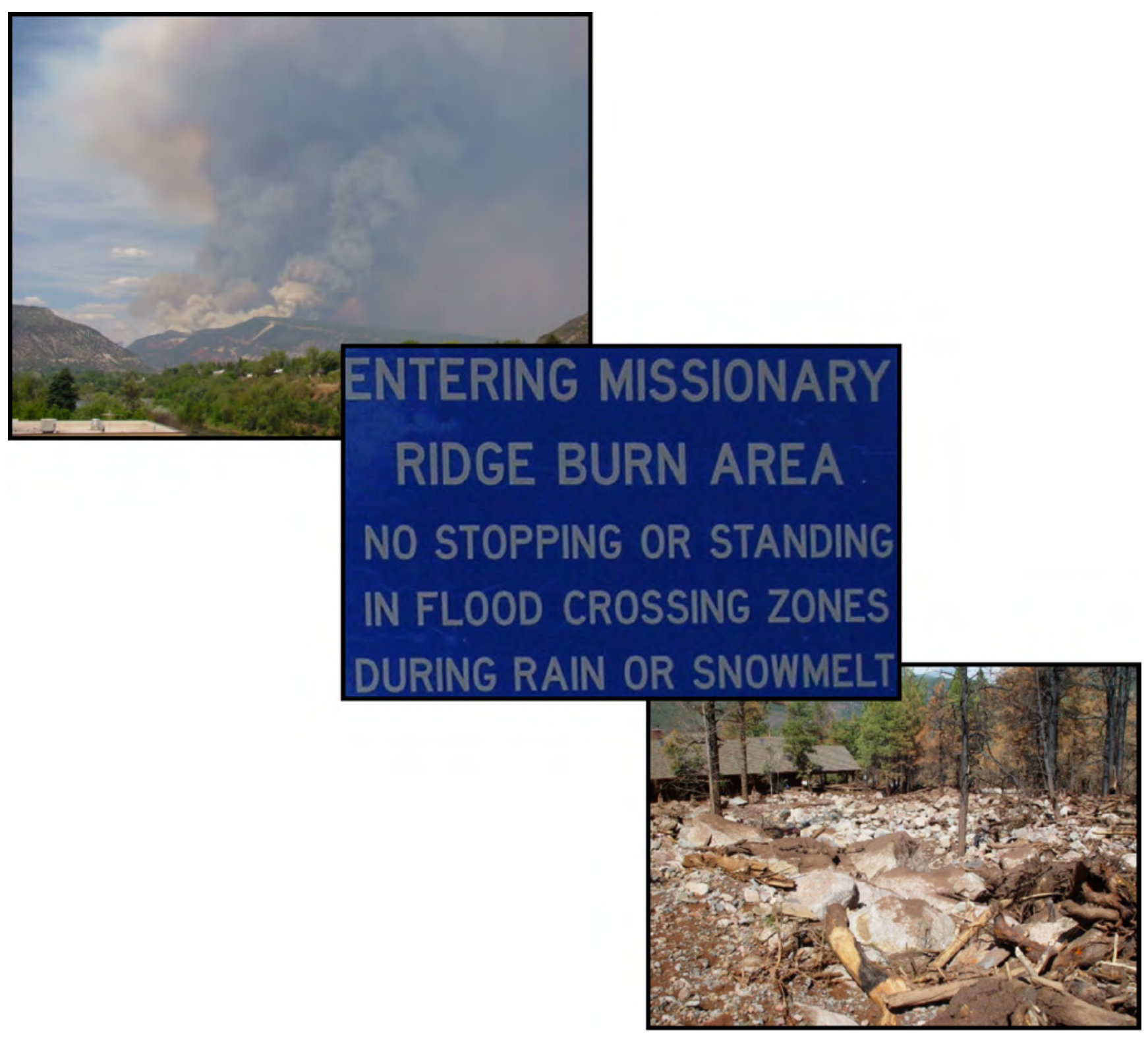

Frontispiece. Left: Missionary Ridge fire, early June, 2002. Photograph courtesy of La Plata County. Center: La Plata County warning sign along Florida River road. Right: Debris-flow deposits on the Stevens Creek fan. Photograph courtesy of La Plata County. 


\title{
U.S. Department of the Interior DIRK KEMPTHORNE, Secretary
}

\author{
U.S. Geological Survey \\ Mark D. Myers, Director
}

U.S. Geological Survey, Reston, Virginia 2007

For product and ordering information:

World Wide Web: http://www.usgs.gov/pubprod

Telephone: 1-888-ASK-USGS

For more information on the USGS - the Federal source for science about the Earth, its natural and living resources, natural hazards, and the environment:

World Wide Web: http://www.usgs.gov

Telephone: 1-888-ASK-USGS

Any use of trade, product, or firm names is for descriptive purposes only and does not imply endorsement by the U.S. Government. This report has not been reviewed for stratigraphic nomenclature.

Although this report is in the public domain, permission must be secured from the individual copyright owners to reproduce any copyrighted material contained within this report.

Suggested citation:

Coe, J.A. (editor), Bigio, E. R., Blair, R.W., Jr., Burke, M., Cannon, S.H., deWolfe, V.G., Ey, J., Gartner, J.E., Gillam, M.L., Knowlton, N.D., Santi, P.M., and Schulz, W.H., Mass wasting following the 2002 Missionary Ridge fire near Durango, Colorado, a field trip guidebook: U.S. Geological Survey Open File Report 2007-1289, 54 p. 
Introduction......................................................................

The Missionary Ridge Fire.....................................................

Geologic and Climatic Setting................................................... 5

Effects of Wildfires on Watersheds.............................................

General Description of Mass Wasting Following the Missionary Ridge Fire.............10

Road Log with Stop Descriptions............................................13

Pullout. Overview of Rockslide from Dakota Sandstone......................13

Stop 1. Overview of Missionary Ridge Fire and Mass Wasting Response........13

Stop 2. Debris Flows on the Stevens Creek Fan ..............................19

Stop 3. Debris flows on the Halflin Creek Fan ............................. 24

Stop 4. Lions Den Picnic Shelter.........................................30

Stop 5. Mitigation at Knight Canyon, Landslides along the Florida River........33

Knight Canyon at Lemon Dam.....................................33

Log Erosion Barriers......................................33

Mulching...............................................37

Seeding.......................................................

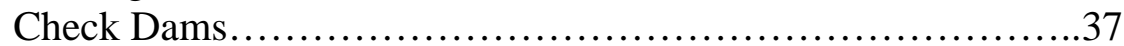

Debris Racks..............................................39

The Florida River Landslide......................................39

Stop 6. Fire and Debris Flow History North of Vallecito Reservoir.............43

Sediment Results................................................45

Tree Ring Results............................................46

Discussion..................................................... 48

Acknowledgements...........................................................49

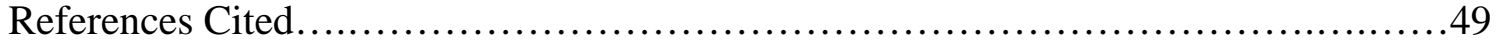

\section{Figures}

1. Map showing the Missionary Ridge fire burn area and field trip stops.......................

2. Map showing burn severity of the Missionary Ridge fire ........................4

3. Geologic map of the Missionary Ridge fire burn area.............................6

4. Stratigraphic section of the Missionary Ridge fire burn area....................... 7

5. Fan at the mouth of Stevens Creek...............................................

6. Rock fall/rock slide from Dakota Sandstone ....................................9

7. Map showing potential peak discharges from the Missionary Ridge fire burn area ...14

8. Comparison of debris-flow volume estimates to model predictions .................17

9. Map showing potential debris-flow volumes from the Missionary Ridge area ........18

10. Debris-flow deposits on the Stevens Creek fan................................21

11. Photographs showing channel migration on the Stevens Creek fan.................22

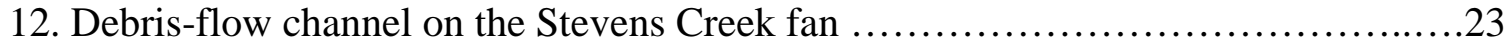

13. Halflin Creek drainage basin and fan.................................................

14. Mountainside near the head of the Halflin Creek drainage basin.....................25 
15. Rills in the Halflin Creek drainage basin .......................................26

16. Ash/mud flow deposit in the Halflin Creek drainage basin .........................26

17. Debris-flow deposits in the Halflin Creek drainage basin ............................27

18. Channel incision in the Halflin Creek drainage basin ............................28

19. Damage from debris flows on the Halflin Creek fan ..............................29

20. View of lower Animas Valley to the north .......................................31

21. Knight Canyon above the spillway intake at Lemon Dam ...........................34

22. Staggered pattern in which log erosion barriers should be placed on a slope .........34

23. Log erosion barriers near Lemon Dam ..........................................35

24. Hand-spread and crimped mulch near Lemon Dam ............................38

25. Vegetative cover from seeding near Lemon Dam...............................38

26. Filled check dam in Knight Canyon near Lemon Dam ...............................39

27. Filled debris rack in Knight Canyon near Lemon Dam............................40

28. Aerial view of the Florida River landslide area ..................................40

29. Geologic map of the Florida River landslide area................................42

30. Debris flow source area in the Florida River landslide area .....................43

31. Study basin on the northwest side of Vallecito Reservoir.........................44

32. Exposed channel reach within the study basin northwest of Vallecito Reservoir.....45

33. Chronology of fine-grained deposition northwest of Vallecito Reservoir ............47

34. Surface fire chronology northwest of Vallecito Reservoir .........................47

\section{Tables}

1. Ages of lower Animas glacial moraines ...........................................32

2. Summary of erosion and sediment control at Lemon Dam ............................36

3. Timeline of erosion and sediment control at Lemon Dam ...........................36 


\section{Conversion Factors}

\section{Inch/Pound to SI}

\begin{tabular}{lcl}
\hline \multicolumn{1}{c}{ Multiply } & \multicolumn{1}{c}{ By } & \multicolumn{1}{c}{ To obtain } \\
\hline Length & & \\
\hline Inch (in.) & 2.54 & centimeter $(\mathrm{cm})$ \\
Inch (in.) & 25.4 & millimeter $(\mathrm{mm})$ \\
foot (ft) & 0.3048 & meter $(\mathrm{m})$ \\
mile (mi) & 1.609 & kilometer $(\mathrm{km})$ \\
yard $(\mathrm{yd})$ & 0.9144 & meter $(\mathrm{m})$ \\
\hline Area & & \\
\hline Acre & 4,047 & Square meter $\left(\mathrm{m}^{2}\right)$ \\
Acre & 0.4047 & hectare $(\mathrm{ha})$ \\
Acre & 0.4047 & Square hectometer $\left(\mathrm{hm}^{2}\right)$ \\
Acre & 0.004047 & Square kilometer $\left(\mathrm{km}^{2}\right)$ \\
square foot $\left(\mathrm{ft}^{2}\right)$ & 929.0 & Square centimeter $\left(\mathrm{cm}^{2}\right)$ \\
square foot $\left(\mathrm{ft}^{2}\right)$ & 0.09290 & Square meter $\left(\mathrm{m}^{2}\right)$ \\
square mile $\left(\mathrm{mi}^{2}\right)$ & 259.0 & hectare $(\mathrm{ha})$ \\
square mile $\left(\mathrm{mi}^{2}\right)$ & 2.590 & Square kilometer $\left(\mathrm{km}^{2}\right)$ \\
\hline Volume & & \\
\hline cubic foot $\left(\mathrm{ft}^{3}\right)$ & 0.02832 & cubic meter per second $\left(\mathrm{m}^{3} / \mathrm{s}\right)$ \\
cubic yard $\left(\mathrm{yd}^{3}\right)$ & 0.7646 & cubic meter $\left(\mathrm{m}^{3}\right)$ \\
\hline Flow rate & & cubic meter $\left(\mathrm{m}^{3}\right)$ \\
\hline cubic foot ${\mathrm{per} \mathrm{second}\left(\mathrm{ft}^{3} / \mathrm{s}\right)}$ & & \\
& & \\
\hline
\end{tabular}




\section{SI to Inch/Pound}

\begin{tabular}{lll}
\hline \multicolumn{1}{c}{ Multiply } & \multicolumn{1}{c}{ By } & \multicolumn{1}{c}{ To obtain } \\
\hline Length & & \\
\hline centimeter $(\mathrm{cm})$ & 0.3937 & Inch (in.) \\
millimeter $(\mathrm{mm})$ & 0.03937 & Inch (in.) \\
meter $(\mathrm{m})$ & 3.281 & foot $(\mathrm{ft})$ \\
kilometer $(\mathrm{km})$ & 0.6214 & Mile $(\mathrm{mi})$ \\
meter $(\mathrm{m})$ & 1.094 & Yard $(\mathrm{yd})$ \\
\hline Area & & \\
\hline square meter $\left(\mathrm{m}^{2}\right)$ & 0.0002471 & acre \\
hectare $(\mathrm{ha})$ & 2.471 & Acre \\
square hectometer $\left(\mathrm{hm}^{2}\right)$ & 2.471 & Acre \\
square kilometer $\left(\mathrm{km}^{2}\right)$ & 247.1 & Acre \\
square centimeter $\left(\mathrm{cm}^{2}\right)$ & 0.001076 & square foot $\left(\mathrm{ft}^{2}\right)$ \\
square meter $\left(\mathrm{m}^{2}\right)$ & 10.76 & square foot $\left(\mathrm{ft}^{2}\right)$ \\
hectare (ha) & 0.003861 & square mile $\left(\mathrm{mi}^{2}\right)$ \\
square kilometer $\left(\mathrm{km}^{2}\right)$ & 0.3861 & square mile $\left(\mathrm{mi}^{2}\right)$ \\
\hline Volume & & \\
\hline cubic meter $\left(\mathrm{m}^{3}\right)$ & 35.31 & cubic foot $\left(\mathrm{ft}^{3}\right)$ \\
cubic meter $\left(\mathrm{m}^{3}\right)$ & 1.308 & cubic yard $\left(\mathrm{yd}^{3}\right)$ \\
\hline Flow rate & & \\
\hline cubic meter per second $\left(\mathrm{m}^{3} / \mathrm{s}\right)$ & 35.31 & cubic foot per second $\left(\mathrm{ft}^{3} / \mathrm{s}\right)$ \\
& & \\
\hline
\end{tabular}




\section{Mass Wasting Following the 2002 Missionary Ridge Fire near Durango, Colorado, a Field Trip Guidebook}

By Jeffrey A. Coe ${ }^{1}$ (editor), Erica R. Bigio ${ }^{2}$, Robert W. Blair, Jr. ${ }^{3}$, Michael Burke ${ }^{4}$, Susan H. Cannon ${ }^{1}$, Victor G. deWolfe ${ }^{5}$, John Ey ${ }^{6}$, Joseph E. Gartner ${ }^{1}$, Mary L. Gillam $^{7}$, N.D. (Butch) Knowlton ${ }^{8}$, Paul M. Santi ${ }^{5}$, and William H. Schulz ${ }^{1}$

${ }^{1}$ U.S. Geological Survey, Denver Federal Center, MS 966, Denver, CO.

${ }^{2}$ Laboratory of Tree Ring Research, University of Arizona, Tucson, AZ.

${ }^{3}$ Consulting Geologist, Professor Emeritus, Department of Geology, Fort Lewis College, Durango, CO.

${ }^{4}$ Recently retired from U.S. Forest Service, Durango, CO.

${ }^{5}$ Department of Geology and Geological Engineering, Colorado School of Mines, Golden, CO.

${ }^{6}$ Florida River Water Conservancy District, Durango, CO.

${ }^{7}$ Consulting Geologist, Adjunct Professor of Geology, San Juan College, Farmington, NM, and Fort Lewis College, Durango, CO.

${ }^{8}$ Office of Emergency Management, La Plata County, CO.

\section{Introduction}

As the title indicates, this field trip guide will focus on mass wasting following the 2002 Missionary Ridge fire near Durango, Colorado (fig. 1). We prepared this guide to accompany a May 4, 2006, field trip during the second Roy J. Shlemon Specialty Conference, which was held in Durango, Colorado, May 3-5. The conference, entitled Mass Wasting in Disturbed Watersheds, was sponsored by the Association of Environmental \& Engineering Geologists (AEG) and the AEG Foundation. The objective of this Shlemon Conference was to bring together practitioners and researchers to define the current state of practice and identify unresolved problems with regard to the prediction and mitigation of mass wasting in disturbed watersheds. The four technical session topics of the conference were (1) post-wildfire mass wasting; (2) logging and mass wasting; (3) mining, urbanization, volcanism, and other disturbances; and (4) emerging technologies and tools (for example, LiDAR, GIS applications, watershed modeling). Shlemon Conferences follow procedures typical of the Geological Society of America Penrose Conferences and the American Geophysical Union Chapman Conferences. Shlemon Conferences are supported, in part, by funds provided by Roy J. Shlemon, a Trustee of the AEG Foundation, an honorary member of the AEG, and a fellow of the Geological Society of America. The conferences provide for an intensive two- to three-day forum of technical discussions among researchers and practitioners, and focus on topics beneficial to society and directly related to application of the engineering and environmental geosciences. The conferences are intended to promote and 
disseminate practice and research results and to foster improvement and understanding of applied geology.

The one-day field trip begins and ends in Durango. Many of the field trip stops are at debris-flow fans around the periphery of the burn area (fig. 1), but one stop examines landslide activity in the burn area that initiated during spring 2005 snowmelt within a dormant, deep-seated landslide, as well as an erosion/debris-flow mitigation effort in a drainage basin above Lemon Reservoir. Stops on fans will focus on (1) erosion and sediment entrainment that caused debris flows in the summer of 2002; (2) Holocene and 2002 debris-flow deposits; and (3) fire history, debris-flow hazards, hazard assessments, and mitigation schemes. A lunch stop provides a geologic overview of the Durango area.

In this guidebook we provide a description of the Missionary Ridge fire, the geologic and climatic setting of the field-trip area, the general effects of wildfire on watersheds, a general description of mass wasting following the Missionary Ridge fire, and finally, a road log including descriptions of each stop.

\section{The Missionary Ridge Fire}

The Missionary Ridge fire began on June 9, 2002, and burned until about July 15, 2002, when containment was declared. The fire occurred during the height of a severe drought in Colorado (Pielke and others, 2005) and was one of 30 wildfires within the State in the spring and summer of 2002 (Colorado Department of Local Affairs, 2002). The fire started in a ditch along Missionary Ridge Road (fig. 1), but the origin of the spark that started the fire is unclear. After inspecting the ditch, a U.S. Forest Service fire investigator concluded that the fire was probably started by a carbon particle spewed from a vehicle exhaust pipe (Greenhill, 2002). The resulting fire was responsible for the death of one person, burned about 73,000 acres (29,000 ha), and destroyed 83 structures (Burn Area Emergency Rehabilitation Team, 2002; La Plata County, 2006).

The fire burned areas north and northeast of Durango, including parts of the Animas, Florida, and Los Pinos River Valleys. The fire burned Ponderosa pine, mixed conifer, aspen, and spruce-fir forests at elevations ranging from about 6,500 ft $(1,980 \mathrm{~m})$ along the Animas Valley to about 11,400 ft (3,475 m) near the northern boundary of the fire. Most of the burned area is characterized by steep mountain sides and canyons and is inaccessible by roads. Burn severity mapping following the fire classified 31 percent of the area as high burn severity, 30 percent as moderate severity, and 39 percent as low severity or unburned (fig. 2; Burn Area Emergency Rehabilitation Team, 2002). About one third (23,000 acres, 9,300 ha) of the total area burned was recommended by the Burn Area Emergency Rehabilitation (BAER) Team for remediation and stabilization efforts (aerial seeding, mulching, log erosion barriers). 


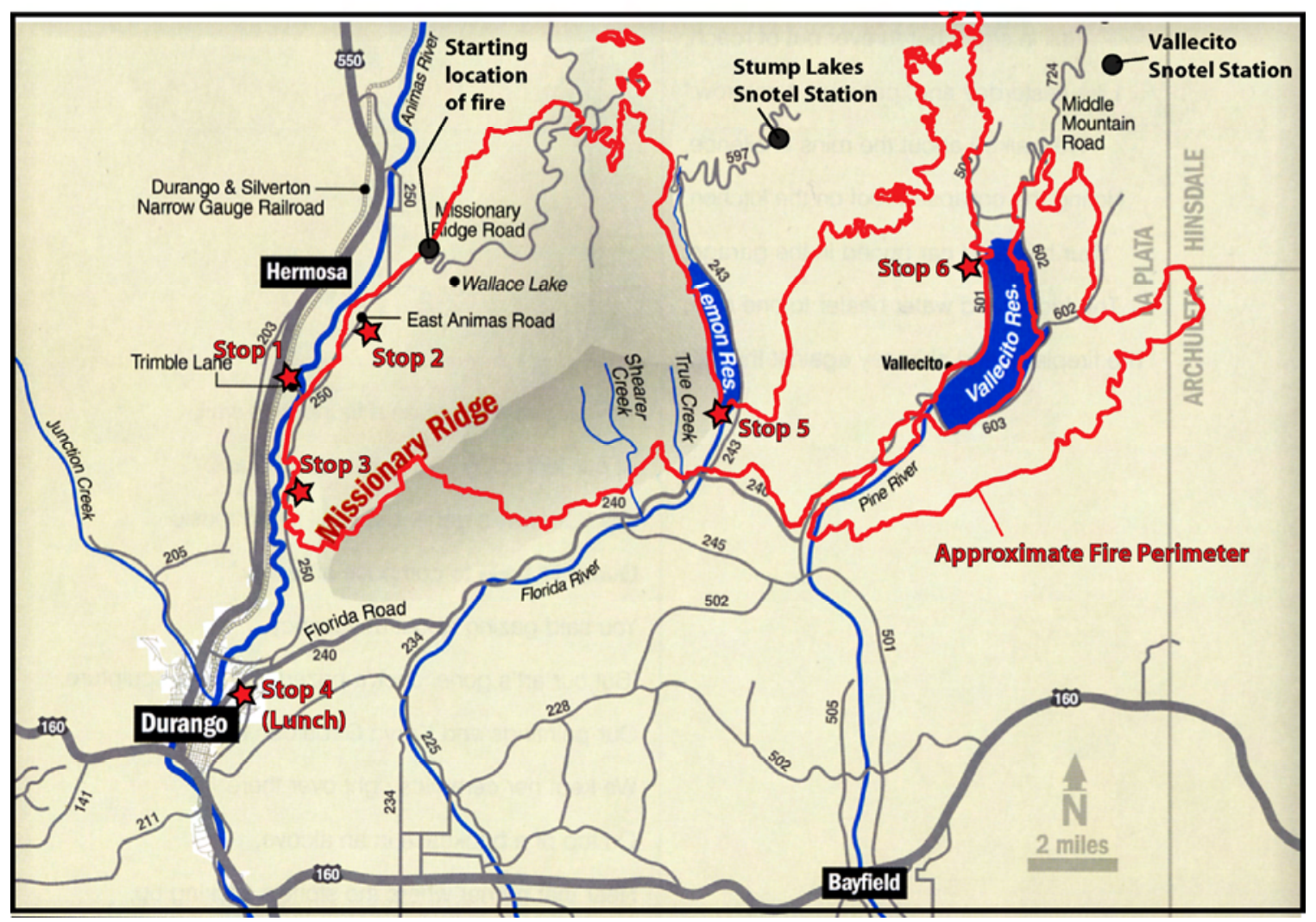

Figure 1. Map showing the Missionary Ridge fire burn area (outlined in red) and field trip stops (indicated by red stars). Base map has been modified from Greenhill (2002). 


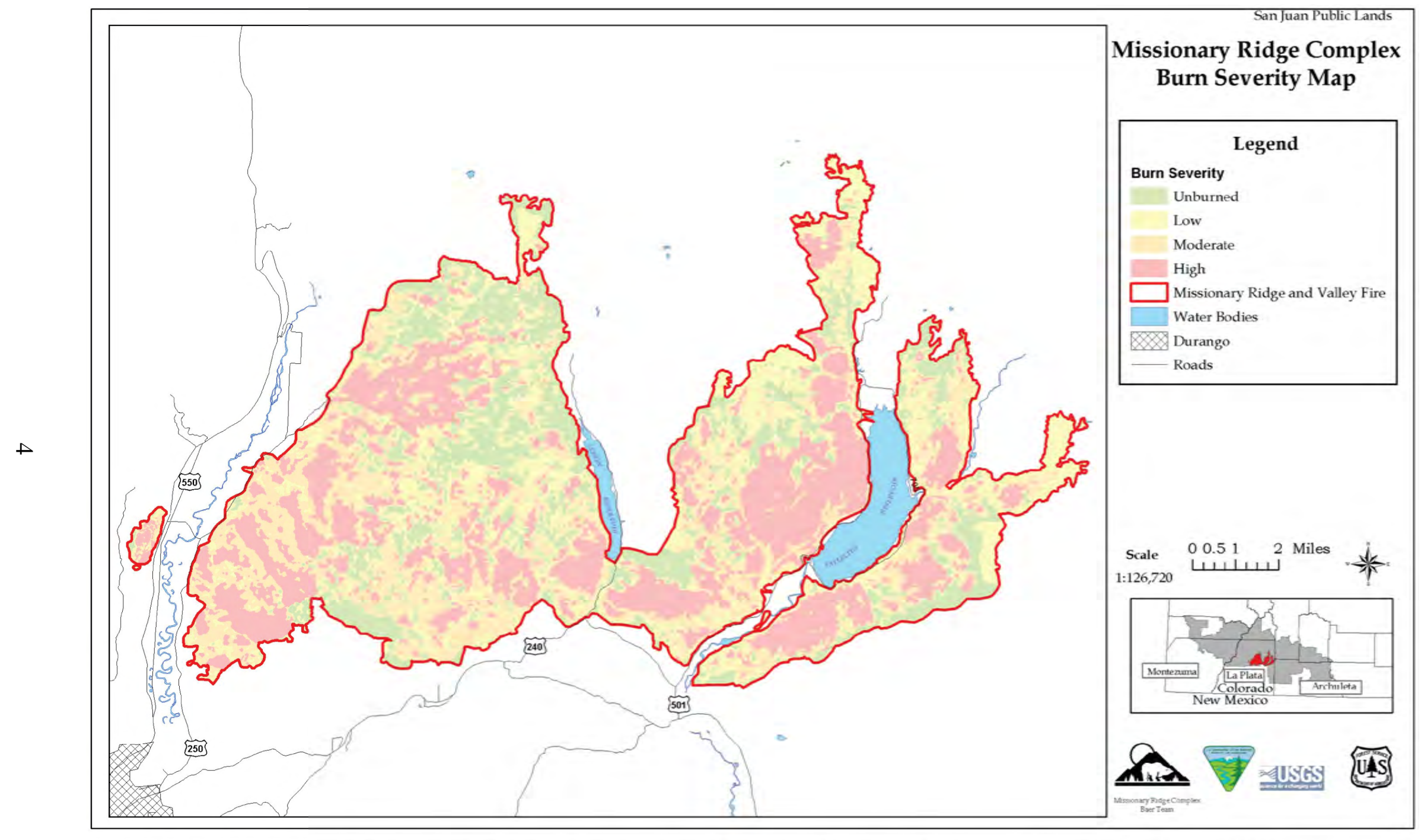

Figure 2. Map showing burn severity of the Missionary Ridge fire. From Burn Area Emergency Rehabilitation Team (2002). 


\section{Geologic and Climatic Setting}

Most of the burned area is underlain by Paleozoic and Mesozoic sedimentary rocks (figs. 3 and 4). About 50 percent of the burn area is underlain by the Permian Cutler Formation, which consists of a sequence of red-colored sandstones, siltstones, and shales deposited by streams flowing from the Ancestral Rocky Mountains (Blair, 1996; Carroll and others, 1997; Carroll and others, 1998; Carroll and others, 1999; Gonzales and others, 2002). Additional sedimentary formations that underlie the burn area include the Hermosa, Molas, Junction Creek, Wanaka, Entrada, Dolores, Dakota, and Morrison Formations (fig. 3). These formations consist of interbedded sandstones, siltstones, shales, limestones, and conglomerates. The Precambrian Eolus Granite also underlies the burn area near the northern boundary. Colluvial and glacial deposits have also been mapped in the burn area.

The area has a semi-arid climate with warm summers and cold winters. Average annual precipitation in Durango (elevation 6,512 ft, 1,985 m) is about 19 in $(480 \mathrm{~mm})$. About one half of this amount falls between July and October during the summer-fall monsoon season, which is characterized by severe thunderstorms. Data from Snotel stations (U.S. Department of Agriculture), located at higher elevations near the burn area, indicate that annual precipitation is about two times greater than that in Durango. At the Vallecito Snotel station (fig. 1; elevation 10,880 ft, 3,316 m), average annual precipitation is 35 in $(889 \mathrm{~mm})$, with about 50 percent falling in the form of snow. At the Stump Lakes Snotel station (fig. 1; elevation 11,200 ft., 3,414 m) average annual precipitation is 40 inches $(1,016 \mathrm{~mm})$, with 50 percent falling as snow.

Mass wasting is common in the area, as evidenced by extensive deep-seated landslide deposits (fig. 3), debris-flow fans (for example, fig. 5), and fresh rock-fall scars and deposits (for example, fig. 6). Deep-seated and shallow landslides are common in the Morrison, Burro Canyon, Dakota, Mancos Shale, and Lewis Shale Formations (for example, Colton and others, 1975; Blair, 1977; Carroll and others, 1997; Carroll and others, 1999; Krochenski and Kenny, 2003; Coe and Burke, 2003). Debris flows are frequently initiated from colluvium derived from the Cutler Formation and Eolus Granite, and less frequently from colluvium derived from the Hermosa and Morrison Formations (Burn Area Emergency Rehabilitation Team, 2002). 


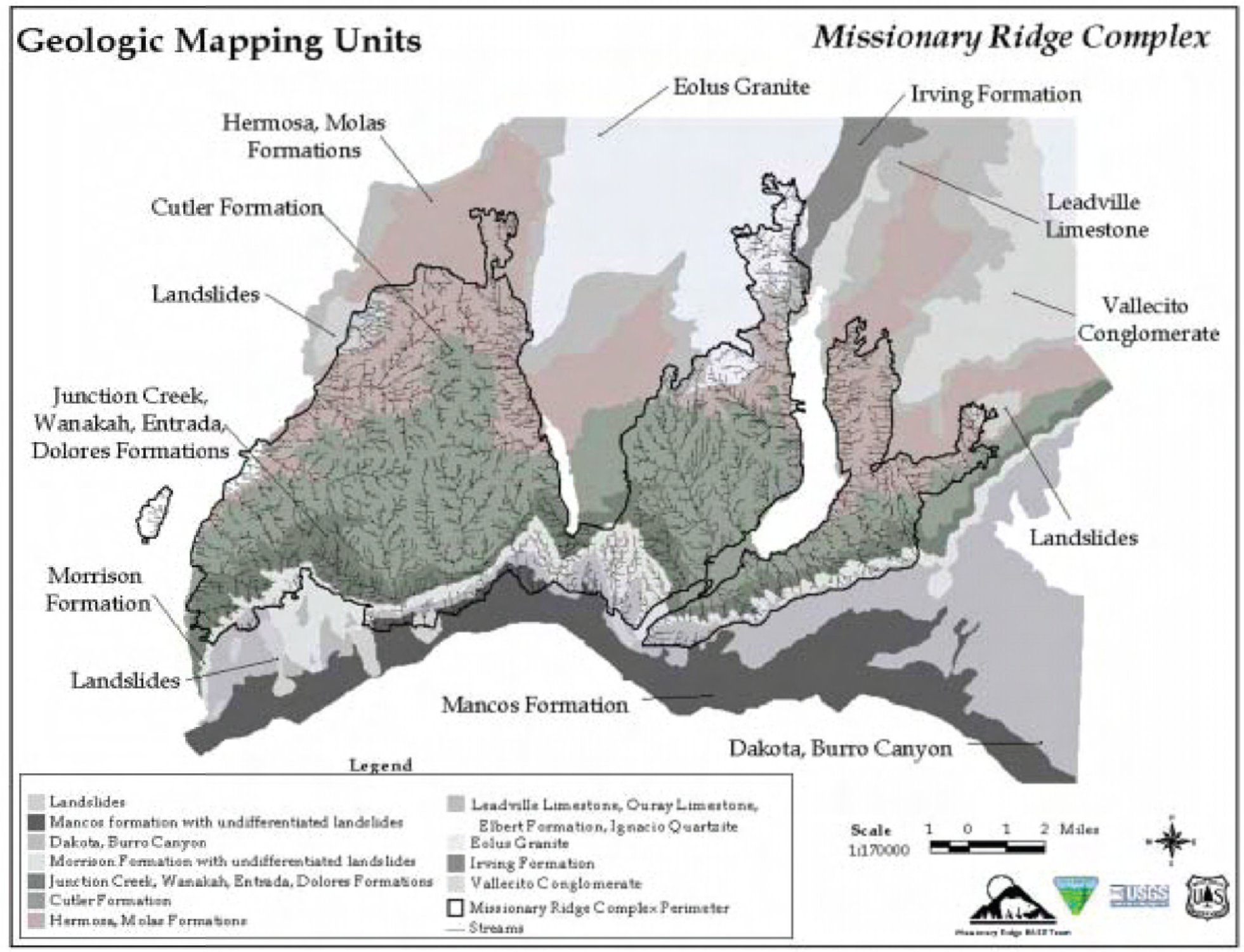

Figure 3. Geologic map of the Missionary Ridge fire burn area. From Burn Area Emergency Rehabilitation Team (2002). 


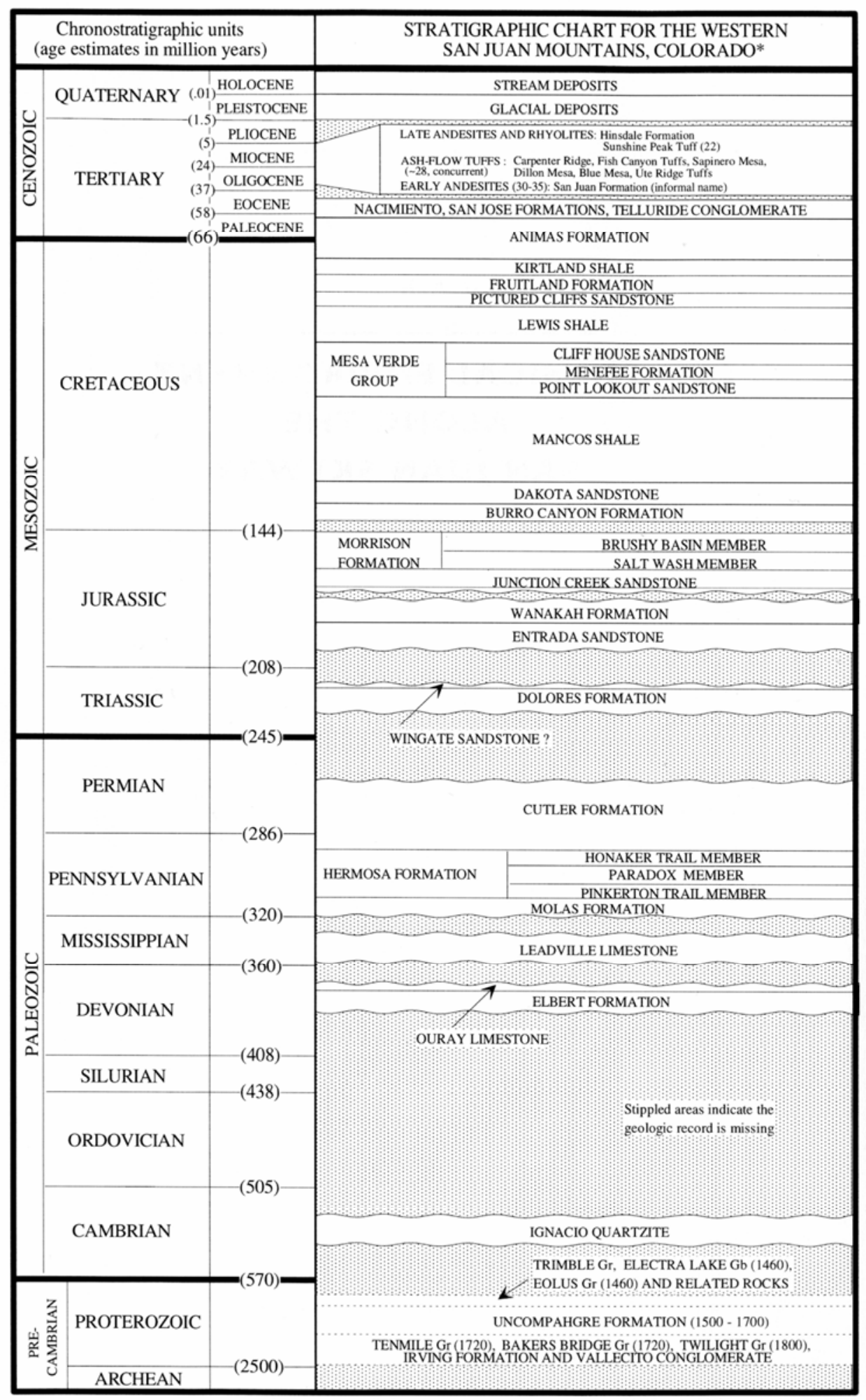

Modified after MacLachlan (1981).

Figure 4. Stratigraphic section of the Missionary Ridge fire burn area. From Blair (1996). 


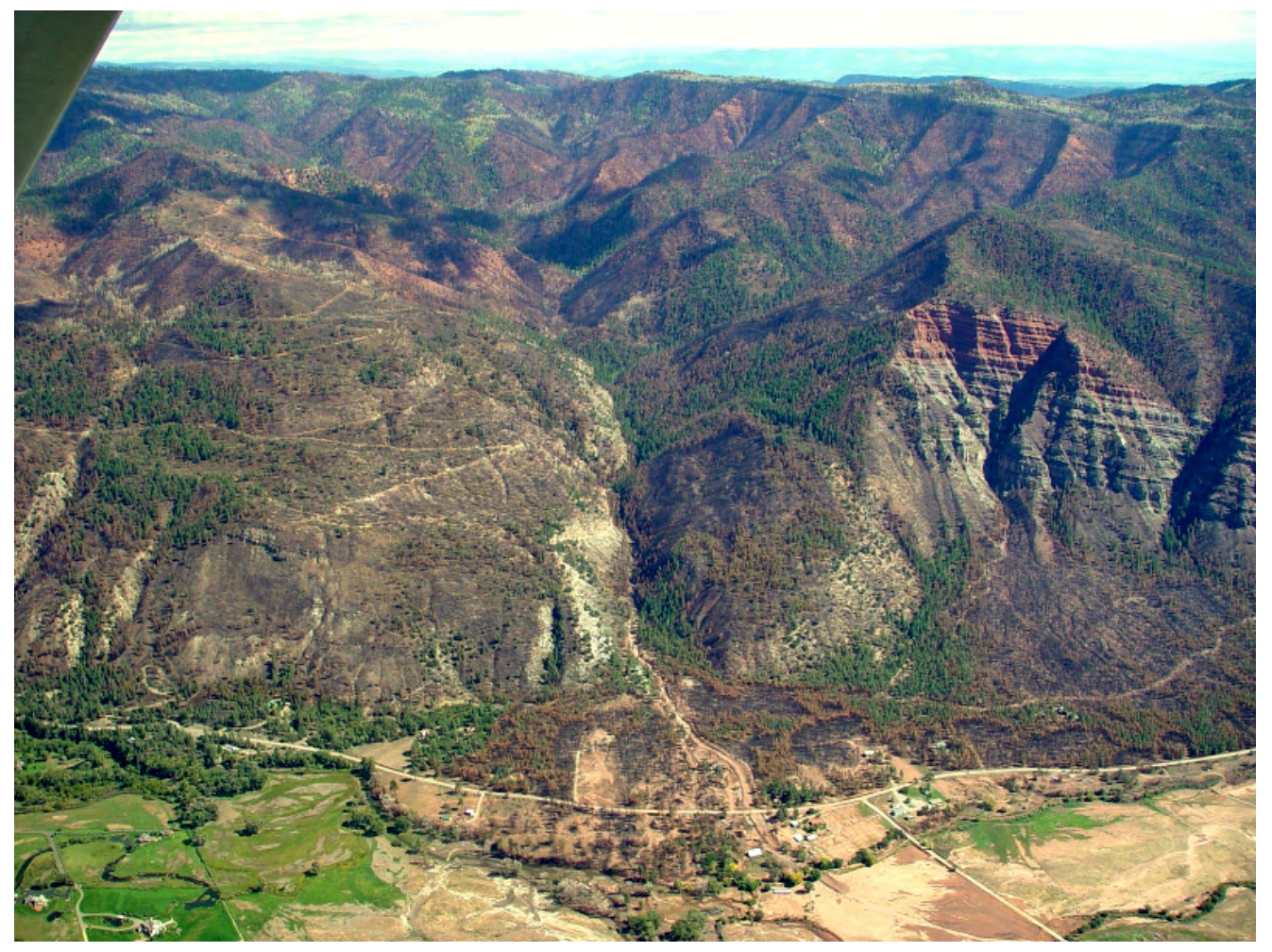

Figure 5. Fan at the mouth of Stevens Creek (Stop 2, fig. 1). Photograph taken after the Missionary Ridge fire. Photograph courtesy of La Plata County.

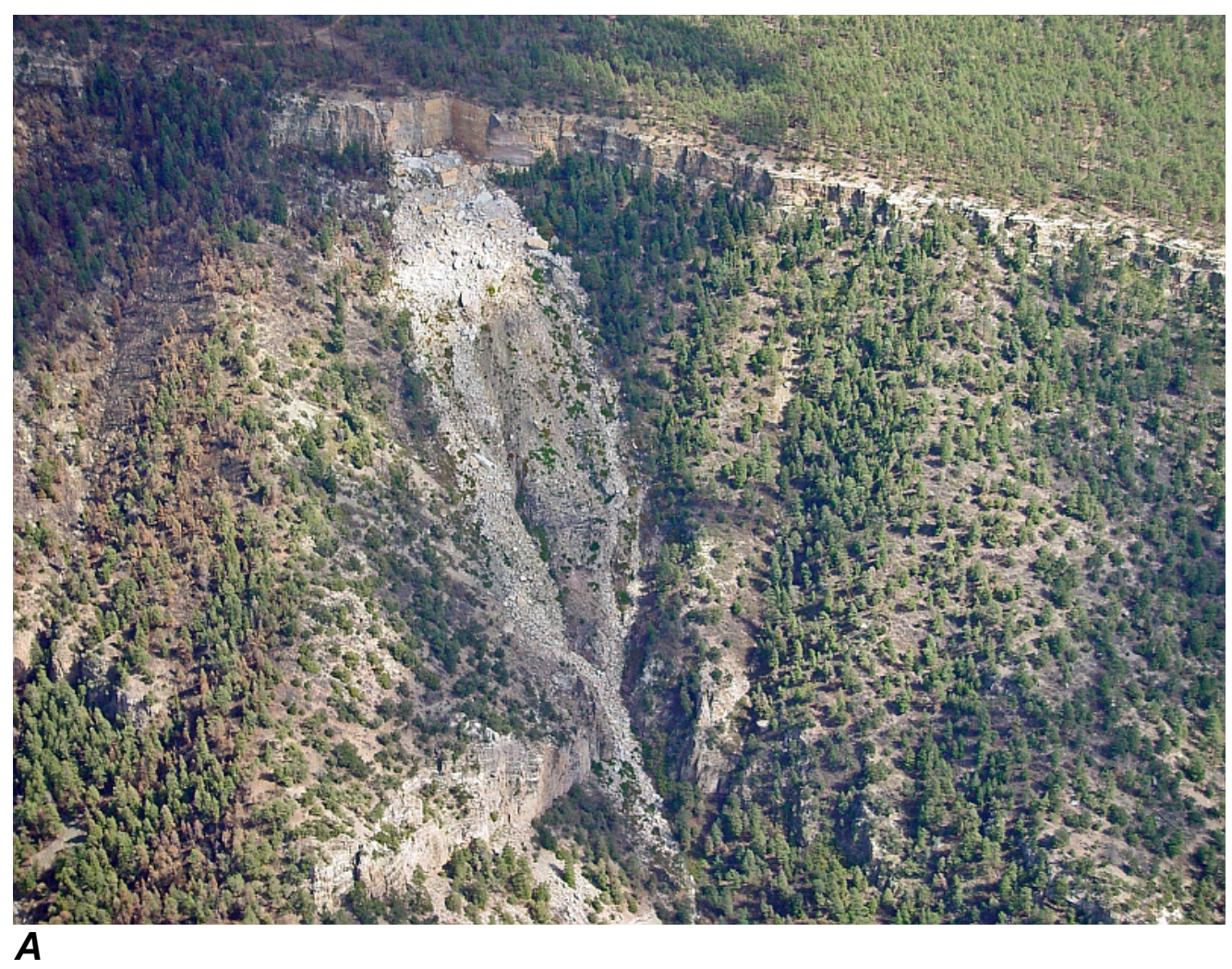




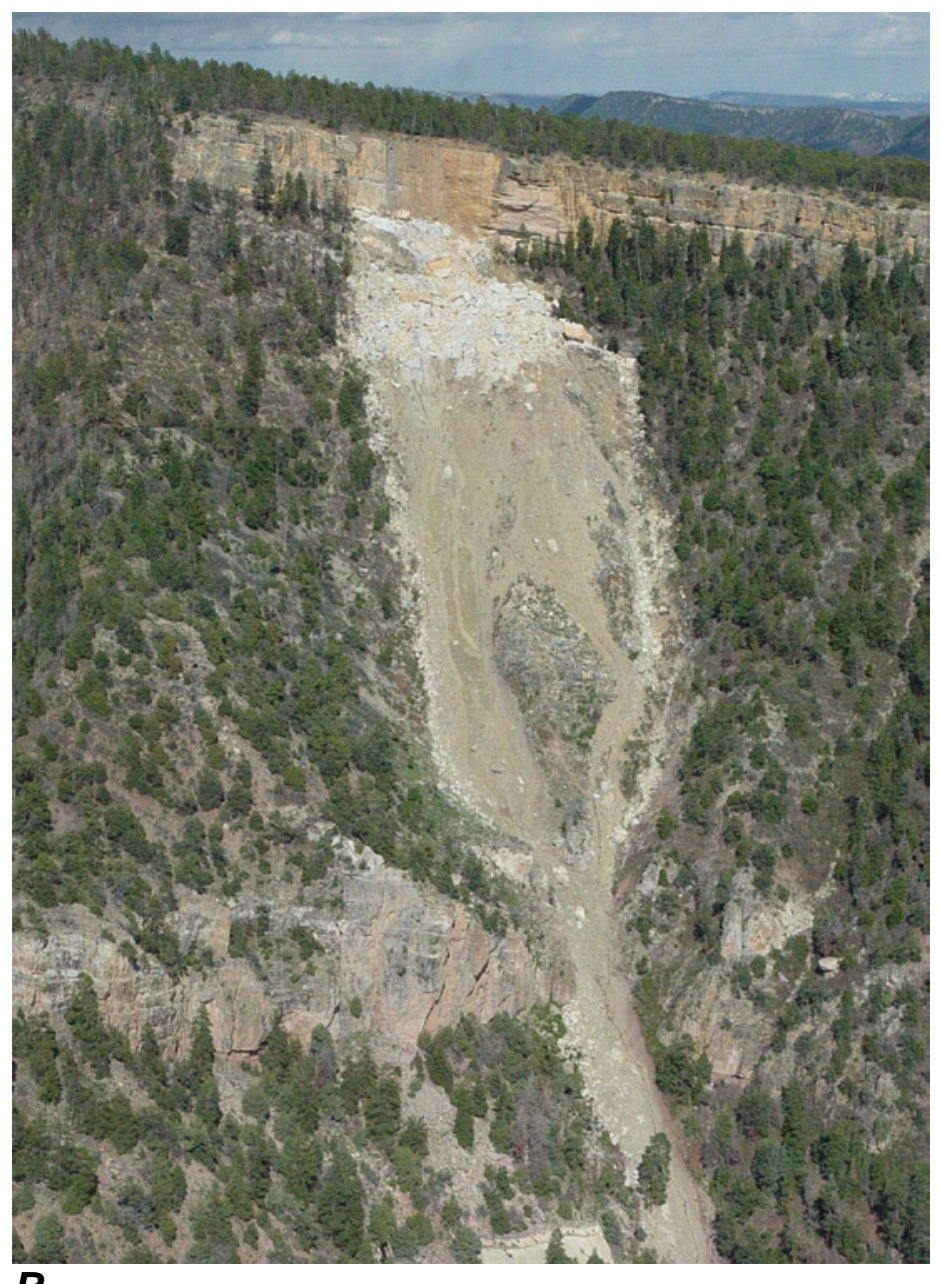

B

Figure 6. Rock fall/rock slide from the Dakota Sandstone along the east side of the Animas River valley about $4 \mathrm{~km}$ north of Durango. A, Photograph taken in the early 2000’s; B, Photograph from 2005.

\section{Effects of Wildfires on Watersheds}

The effects of wildfires on watersheds have been described by Cannon and others (2003a) and the text in this section has been extracted from this previously published work. Wildfire can have profound effects on a watershed. Consumption of the rainfallintercepting canopy and of the soil-mantling litter and duff, intensive drying of the soil, combustion of soil-binding organic matter, and the enhancement or formation of waterrepellent soils can result in decreased rainfall infiltration into the soil and can significantly increase overland flow and runoff in channels (for example, Doerr and others, 2000; Martin and Moody, 2001; Moody and Martin, 2001). Removal of obstructions by wildfire can enhance the erosive power of overland flow, resulting in accelerated erosion of material from hillslopes (Meyer, 2002). Increased runoff can also 
erode significant volumes of material from channels, the net result being the transport and deposition of large volumes of sediment both within and down-channel from the burned area.

Debris flows are frequently produced in response to convective thunderstorm activity over basins burned by wildfire (Parrett, 1987; Meyer and Wells, 1997; Cannon, 2001; Cannon and Gartner, 2005), as well as in response to winter frontal storms (Morton, 1989; Cannon, 2000). Debris flows pose a hazard distinct from other sedimentladen floods because of their unique destructive power; debris flows can occur with little warning and exert large impulsive loads on objects in their paths. Even small debris flows can strip vegetation, block drainage ways, damage structures, and endanger human life.

\section{General Description of Mass Wasting Following the Missionary Ridge Fire}

In general, the Missionary Ridge fire increased the frequency and volume of mass-wasting events (particularly debris flows) in the burn area. The following narrative describes (1) the runoff response of the burn area to monsoon rainstorms in the summer and fall of 2002 (from Cannon and others, 2003a; see fig. 7 for basin locations and fig. 1 for County roads mentioned below) and (2) the response of a large, deep-seated landslide near Lemon Reservoir following rapid snowmelt of heavy winter snowpack in the spring of 2005 (Schulz and others, 2006).

July 11, 2002. - The first storm to affect the area burned by the Missionary Ridge fire was a localized thunderstorm that impacted the area south of the Vallecito Reservoir dam. La Plata County Road (CR) 501 and a softball field were flooded with ash and mud flushed from the hillslopes. This storm occurred before a rain-gage network had been installed; thus no precipitation record is available.

July 22, 2002.- This storm resulted in a similar flush of ash and mud from the burned hillslopes near Vallecito Reservoir. CR 501 was closed between the Vallecito Reservoir dam and the intersection of CR 240 in order to clear ash, mud, debris, and a 400-lb (180-kg) boulder that was moved by the flood waters (Kostka, 2002). Red Creek also showed significant flood activity.

July 23, 2002.- This first significant storm of the season impacted the Florida and Los Pinos River basins. Debris flows were produced from an unnamed basin just below Lemon Reservoir, and significant sediment-laden floods were produced from Dry, Shearer, and True Creeks. At least five vehicles, four of which contained people, were swept off CR 240 by the advancing water (Kostka and others, 2002). The debris flow from unnamed basin 1 crossed CR 243, blocked a driveway, and damaged a guardrail on a bridge. Material consisting of ash, fine-grained sand, gravel, and clasts up to $3 \mathrm{ft}(1 \mathrm{~m})$ in diameter was deposited up to $4 \mathrm{ft}(1.2 \mathrm{~m})$ deep on the road. This storm also resulted in sediment-laden floods that crossed CR 501 along Vallecito Reservoir in several places.

August 3, 2002.-This storm resulted in the generation of debris flows from many basins within the Los Pinos River drainage and along CR 240. A debris flow was produced from Freeman Creek at about 12:15 p.m. Material up to $6 \mathrm{ft}(2 \mathrm{~m})$ in diameter was moved in this event, and passage of the flow resulted in nearly $5 \mathrm{ft}(1.5 \mathrm{~m})$ of incision of the channel bed. Debris flows crossed CR 501 in several places near Freeman 
Creek. Root Creek also produced a debris flow that deposited material approximately 10 $\mathrm{ft}(3 \mathrm{~m})$ deep, including boulders up to $6 \mathrm{ft}(2 \mathrm{~m})$ in diameter, at the junction with $\mathrm{CR}$ 501. Debris flows also crossed CR 240 in several places.

August 5, 2002.-Debris flows were again reported to have been produced from unnamed basin 1, where materials up to $4 \mathrm{ft}(1.2 \mathrm{~m})$ in diameter in abundant muddy matrix crossed CR 243. Sediment-laden streamflow events occurred along CR 501 near Vallecito Reservoir.

August 8, 2002.- This storm brought rain to the Animas, Florida, and Los Pinos River basins. Unnamed basin 2 produced a debris flow that deposited ash, mud, and debris at a business located across CR 501. This event moved material up to $3 \mathrm{ft}(1 \mathrm{~m})$ in diameter across the road. Sediment-laden streamflow was produced from many of the smaller drainages north of unnamed basin 2, and flooding in Freeman Creek led to additional incision in the channel bed. Unnamed basin 3 (fig. 7) produced a debris flow that deposited levees approximately $3 \mathrm{ft}(1 \mathrm{~m})$ high that lined the channel; material up to $3 \mathrm{ft}(1 \mathrm{~m})$ in diameter was transported in a muddy matrix by this event. Adjacent Dry Creek showed evidence of sediment-laden streamflow. Root Creek also experienced a debris flow, and a sediment-laden flood was produced in Elkhorn Canyon along the Animas River. Material from the Elkhorn Canyon event covered CR 250 with about $1 \mathrm{ft}$ $(0.3 \mathrm{~m})$ of ash and mud.

August 20, 2002.- This storm resulted in the generation of sediment-laden floods from Freeman and Dry Creeks, as well as from unnamed basin 3.

August 21, 2002.-An apparently localized storm resulted in the production of another debris flow from Root Creek and light flooding in adjacent drainages. Passage of the flow in Root Creek resulted in approximately $3 \mathrm{ft}(1 \mathrm{~m})$ of channel incision, and significant deposition along the channel banks. Material up to $3 \mathrm{ft}(1 \mathrm{~m})$ in diameter was transported by this event. Deposits from sediment-laden floods were also observed at the mouth of Freeman Creek.

August 29, 2002.-A localized rainstorm triggered debris flows from Haflin and Kroeger Canyons in the Animas Valley. The flows carried material no greater than $3 \mathrm{ft}$ $(1 \mathrm{~m})$ in diameter in a muddy matrix.

September 7, 2002.- This was the first storm that produced debris flows in multiple basins that drain into the Animas River. Debris flows were produced from Coon Creek, Stevens Creek, Freed Canyon, and Woodard Canyon. These events blocked CR 250 in three places with several feet of debris. The event on Stevens Creek covered approximately one quarter of the fan area with deposits up to $5 \mathrm{ft}(1.5 \mathrm{~m})$ deep in places and inundated a home with tons of rock and mud. Prior to the event, the home was at least $200 \mathrm{ft}(62 \mathrm{~m})$ from the active channel. This event moved material up to $8 \mathrm{ft}(2.5 \mathrm{~m})$ in diameter in a muddy matrix. Evidence on the fan surface suggests that channels were blocked by large boulders and were diverted many times during the event. Upstream from the fan, the channels showed up to $8 \mathrm{ft}(2.5 \mathrm{~m})$ of incision into extensive valley-fill deposits. The debris flow produced from Freed Canyon moved materials up to $6 \mathrm{ft}(2 \mathrm{~m})$ in diameter in a muddy matrix. The high mud line produced from this event was measured $12 \mathrm{ft}(4 \mathrm{~m})$ above the post event channel base, and up to $6 \mathrm{ft}(2 \mathrm{~m})$ above the original bank levels. The area downstream from the waterfall at the head of the fan was heavily scoured in this event. Deposition by the debris flow in Coon Creek resulted in the shifting of the channel bed to the north by about $10 \mathrm{ft}(3 \mathrm{~m})$. Material from this event consisted of up to cobble-sized material in a muddy matrix. In addition to these events, 
sediment-laden floods near Red, Shearer, and True Creeks blocked CR 240 in the Florida River basin.

September 10-12, 2002.- This storm had the longest duration of any that occurred during the 2002 monsoon season. The storm started on the evening of September 10 and continued into the early morning hours of September 12. Debris flows were again produced from Coon and Stevens Creeks and Woodard Canyon, but these were smaller discharge events than those of September 7, carrying smaller (up to cobble-sized) material. Deposition by debris flow on Coon Creek filled in the channel and shifted the channel to the south. Soil slip scars that formed during this storm were observed in the upper reaches of Stevens Creek. These scars were relatively small-at most $100 \mathrm{ft}^{2}\left(10 \mathrm{~m}^{2}\right)$ in area. Material from these scars mobilized into debris flows that traveled a few hundred feet down the hillslopes on which they originated. Debris flows were also produced from Root Creek near Vallecito Reservoir and from unnamed basin 1 near Lemon Reservoir. Sediment-laden floods also resulted in the closure of CR 501 at Jack and Dry Creeks near Vallecito Reservoir.

September 20, 2002.-A storm focused on the southern end of the Animas Valley front produced debris flows from Haflin and Kroeger Canyons and from Stevens Creek. These events carried materials only up to about $1.5 \mathrm{ft}(0.5 \mathrm{~m})$ in diameter, a significant decrease in size from previous events. These events appear to have been triggered by a fairly localized storm, as rain gages located nearest to the canyons did not record any rainfall on this date.

October 2, 2002.- - The last of the monsoon storms of 2002 to impact the area produced sediment-laden floods on Coon Creek. These events reworked the existing deposits and scoured the south side of the channel.

Summary of 2002 events_-Evaluation of the storm conditions that resulted in the 2002 events shows that most of the debris-flow and flood-triggering storms had recurrences of less than 2 yrs; only one gage (in the July 23, 2002, storm) recorded a 10yr recurrence event (Cannon and others, 2003a).

April and May, 2005.- - Landslide activity on a steep, burned hillslope southeast of Lemon Dam included the formation of at least nine shallow (approx. 2-m (6-ft) thick) colluvial landslides that mobilized into more than a dozen debris flows. Activity was concentrated on a very large, apparently dormant landslide. Landslides within the colluvium were translational debris slides (Cruden and Varnes, 1996) with volumes between 2,600 and 46,000 $\mathrm{yd}^{3}\left(2,000\right.$ and 35,000 $\left.\mathrm{m}^{3}\right)$. Debris flows were generally mobilized from dilated, mostly saturated, toe regions of the slides and ranged in volume from 200 to $2,000 \mathrm{yd}^{3}$ (150 to $1,500 \mathrm{~m}^{3}$ ). Although generally quite small, debris flows traveled as far as about $980 \mathrm{ft}$ (300 m) downslope onto the Florida River floodplain. The landslides were triggered by rapid melting of deep snow with a high water content. Area residents had not observed landsliding on the hillslope previously (during about the past $30 \mathrm{yrs}$ ), although similar snowmelt events have occurred historically. 


\section{Road Log with Stop Descriptions}

From downtown Durango proceed north on Highway 550. About 2.5 miles (4 $\mathrm{km})$ north of the Durango city limit (just north of the Days Inn), pull off the road into the large pullout on the west side of Highway 550.

\section{Pullout. Overview of Rockslide from Dakota Sandstone}

GPS location: N $37^{\circ} 19^{\prime} 44.5^{\prime}$ 'W $107^{\circ} 51^{\prime}$ 07.0” Elevation: 6,589 ft. (2,008 m). Discussion Leader: Rob Blair.

A glance to the east reveals a landslide scar from Dakota Rim rock (fig. 6). This rockslide occurred at approximately 10:30 a.m. on July 5, 1998. Eye-witness reports ranged from a forest fire (from all the dust), to an airplane crash, to rock fall. Approximately $37,000 \mathrm{yd}^{3}$ (28,500 $\mathrm{m}^{3}$ or 74,000 metric tons) of Dakota Sandstone rock toppled and slid downslope after being undercut by natural weathering of clays that underlie the rock stratum. Years of snowmelt and water seepage down through joints and along the sandstone-clay boundary allowed gravity creep of the overlying rock to occur. As an interesting side note, the property owners held a Forth of July party to view the Durango fireworks on the very rocks that collapsed the following day. They videotaped the picnic with astute comments about "someday this will fail" as they leaped across a gaping crack from bedrock to the block that fell.

Recent photos and observations from residents living near the base of the rockslide slope suggest that parts of the deposit have subsequently mobilized as debris flows (compare fig. 6A to 6B).

Continue north on Highway 550, then turn east on CR 252. Cross over the railroad tracks and turn left into a large pullout on the north side of the road.

\section{Stop 1. Overview of Missionary Ridge Fire and Mass Wasting Response}

Pullout on north side of CR 252 immediately east of the railroad tracks. GPS location: N 37 23' 24.8' W $107^{\circ} 50^{\prime} 44.0^{\prime}$ ' Elevation: 6,530 ft. (1,990 m). Stop Leaders: Butch Knowlton, Sue Cannon, Joe Gartner.

The west-facing flank of the Animas Valley is visible to the east from this stop. The Missionary Ridge fire started about 4.5 miles ( $7 \mathrm{~km}$ ) northeast of this stop, but burned primarily to the east and south toward Durango. The fire burned portions of about 90 drainage basins (fig. 7). Most of these basins were uninhabited, but many of the fans at the mouths of the basins were populated with houses and public and private roads. A large part of the response of local, State, and Federal officials following the fire dealt with providing warnings and predictive maps for fan areas.

A system of warning signs, signals, and maps was established by several cooperating agencies. First, La Plata County installed numerous warning signs along county roads around the periphery of the burn area (for example, see Frontispiece). These signs served as a reminder to motorists to be aware of weather conditions and take appropriate precautions. 


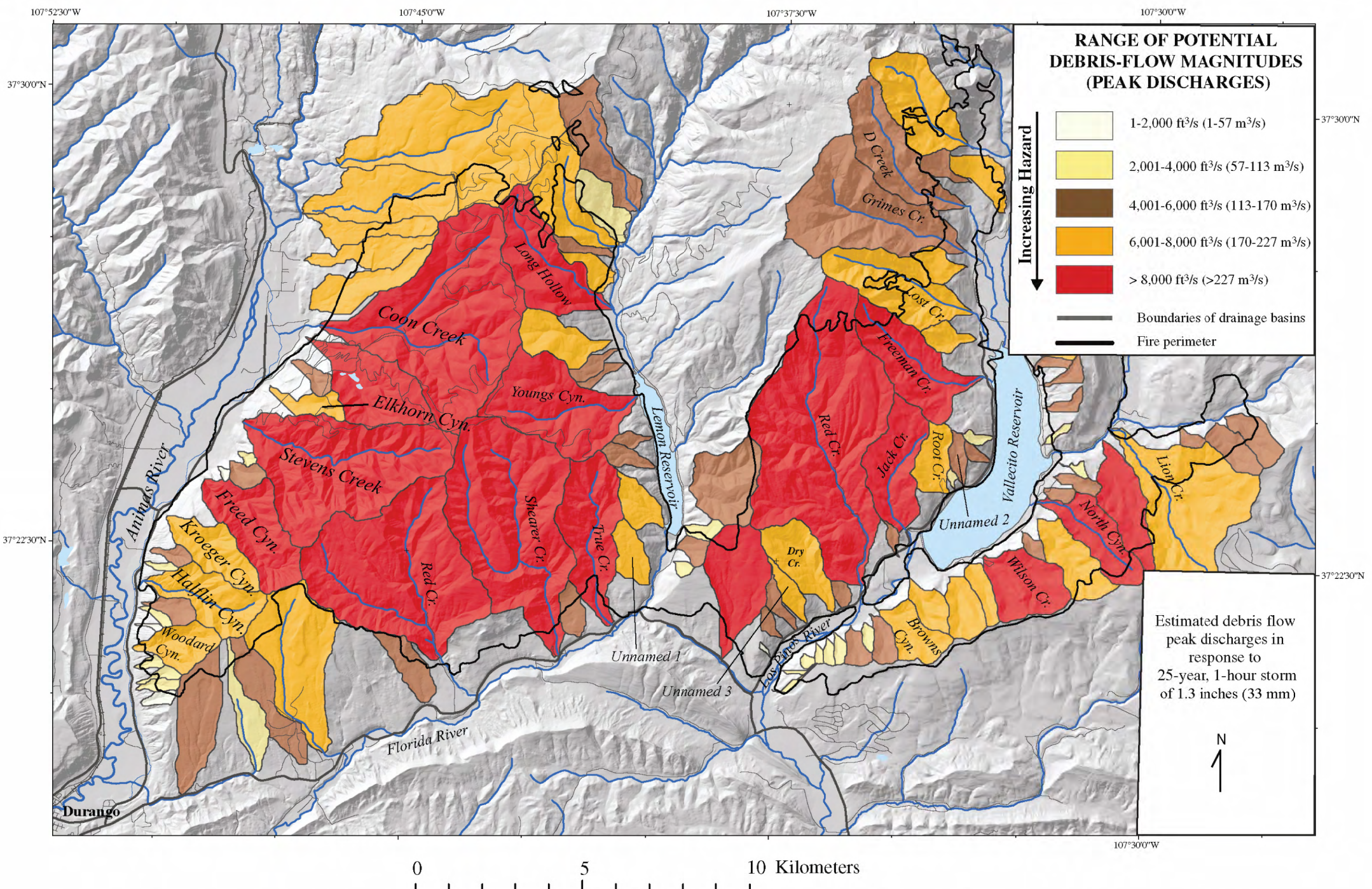

Figure 7. Map showing potential peak discharges of debris flows from basins in the Missionary Ridge fire burn area for a 1-hr duration, 25 -yr recurrence storm of 1.3 in $(33 \mathrm{~mm})$. From Cannon and others (2003b). 
Second, after recognizing the extreme flood and debris-flow potential for areas around the periphery of the burn area, the Federal BAER Team requested that the U.S. Geological Survey install a series of rain gages to monitor rainfall in the burn area. These rain gages were positioned at 12 locations and equipped with satellite telemetry communication. The National Weather Service office in Grand Junction received the real-time rain gage information and utilized a National Oceanic and Atmospheric Administration all-hazards weather radio transmitter installed on Missionary Ridge to broadcast weather and emergency information. All citizens in La Plata County, particularly in areas near the burn area, were encouraged to purchase a weather radio receiver. La Plata County cooperated with the National Weather Service to activate the radios to provide warnings and weather information to areas near the fire perimeter that could be affected by storms and flooding.

Third, predictive hazard maps for peak debris-flow discharges and debris-flow volumes were produced for the burn area. Peak-discharge maps were generated immediately after the fire, and are based on a preliminary regression model developed using debris-flow and basin characteristic data from 53 recently burned basins throughout the intermountain west (Cannon and others, 2003c). The model used to estimate peak debris-flow discharges (Qp) for basins in the Missionary Ridge area was:

$$
Q p / I=-4.5 \times 10^{7}-4.2 \times 10^{4}\left(\mathrm{~S}_{50}\right)+1.1 \times 10^{7}\left(\log A_{b}\right),
$$

where $I$ is average storm rainfall intensity $(\mathrm{m} / \mathrm{s}), S_{50}$ is the percentage of slopes greater than or equal to 50 percent within a basin, and $A_{b}$ is the area burned within a basin. Slope values were determined from 10-m or 30-m Digital Elevation Models (DEMs) and burned area values were determined by BAER Teams or from Landsat Thematic Mapper data. Results from this model for a 1-hr rainstorm of 1.3 in $(33 \mathrm{~mm})$ and a 25-yr return period are shown in figure 7. Assessments for 1-hr duration, 5- and 100-yr recurrence storms were also generated (Cannon and others, 2003a).

Unfortunately (or fortunately, as the case may be) most of the storms that impacted the Missionary Ridge area had recurrence intervals of less than 2 yrs, and only one rain gage during the July 23, 2002, storm recorded a 10-yr recurrence storm (Cannon and others, 2003a). Thus, comparisons of actual responses with the predicted values in individual basins were difficult. However, some broad-based estimates of peak discharges using surveys of channel cross sections following the September 7, 2002, event, and an assumed velocity of $16 \mathrm{ft} / \mathrm{s}(5 \mathrm{~m} / \mathrm{s})$, produced values of about $5,500 \mathrm{ft}^{3} / \mathrm{s}$ $\left(165 \mathrm{~m}^{3} / \mathrm{s}\right)$ at the head of the Stevens Creek fan (Cannon and others 2003a). This value is within the range of the predicted value for a 5-yr recurrence storm $\left(4,001-6,000 \mathrm{ft}^{3} / \mathrm{s}\right.$, $113-170 \mathrm{~m}^{3} / \mathrm{s}$, from Cannon and others, 2003b). In general, the peak-discharge maps gave a good indication of those basins that produced the largest events.

Elliott and others (2004) modeled a 100-yr recurrence, 1-hr duration storm in this setting using the U.S. Army Corps of Engineers Hydrologic Modeling System (HECHMS). Estimated peak discharges for Stevens Creek were between 2,186 and 3,835 ft $\mathrm{ft}^{3} / \mathrm{s}$ $\left(62-109 \mathrm{~m}^{3} / \mathrm{s}\right)$. For the same storm, Cannon and others (2003a) estimated peak discharges of greater than $8,000 \mathrm{ft}^{3} / \mathrm{s}\left(227 \mathrm{~m}^{3} / \mathrm{s}\right)$. Comparisons of predicted values with 
actual response were again not possible because a 100-yr recurrence storm has not occurred in the burn area since the fire.

Pierson (2005) described the limited usefulness of peak-discharge measurements for debris flows due to orders-of-magnitude changes over short distances, and the difficulties in characterizing velocities using standard methods. For this reason, Gartner (2005) developed a model for characterizing debris-flow magnitude in terms of volume rather than in peak discharge.

Gartner (2005) derived potential debris-flow volume estimates based on a regression model developed using debris-flow channel and basin characteristic data from 56 recently burned basins in Colorado, Utah, and California. In each of the 56 basins, debris-flow volumes were estimated by quantifying the amount of material eroded from the main channels using post-debris flow surveys of closely spaced channel cross sections. Post-debris-flow cross sections were compared to interpolated cross sections of the original channel surface to estimate the amount of material eroded at each location. The original channel surface was estimated based on the assumption that the channel was v-shaped prior to erosion during post fire debris flows. Measures of basin morphology were calculated from 10- or 30-m digital-elevation models. Maps of burn severity were used to quantify the basin areas burned at low, moderate, and high severities. Material properties for each basin were characterized by different measures of the grain-size distribution determined from field samples of burned soil. The dominant rock type underlying the debris-flow-producing basin was characterized either from field observations or from geologic maps. Networks of rain gages installed throughout the burned areas provided rainfall amounts and intensities for debris-flow-triggering storms.

Gartner (2005) used a series of stepwise multiple-regression analyses to develop a best-fit model to estimate potential debris-flow volumes in the Western U.S. The model is:

$$
\ln V=0.65(\ln S)+0.86(B)^{1 / 2}+0.22(R)^{1 / 2}+6.46
$$

where $V$ is debris-flow volume $\left(\mathrm{m}^{3}\right), S$ is basin area with slopes greater than or equal to 30 percent $\left(\mathrm{km}^{2}\right), B$ is basin area burned at moderate and high severity $\left(\mathrm{km}^{2}\right)$, and $R$ is total storm rainfall (mm). As indicated by this equation, material properties and geology units had low correlation coefficients and were not used in the model.

The model for debris-flow volume was validated by comparing predicted debris flow volumes with reported volumes using data from 21 basins not used in the generation of the model (Gartner, 2005). The validation indicated that all but seven, or 67 percent, of the reported volumes were within one standard error of the volumes predicted by the model (fig. 8). 


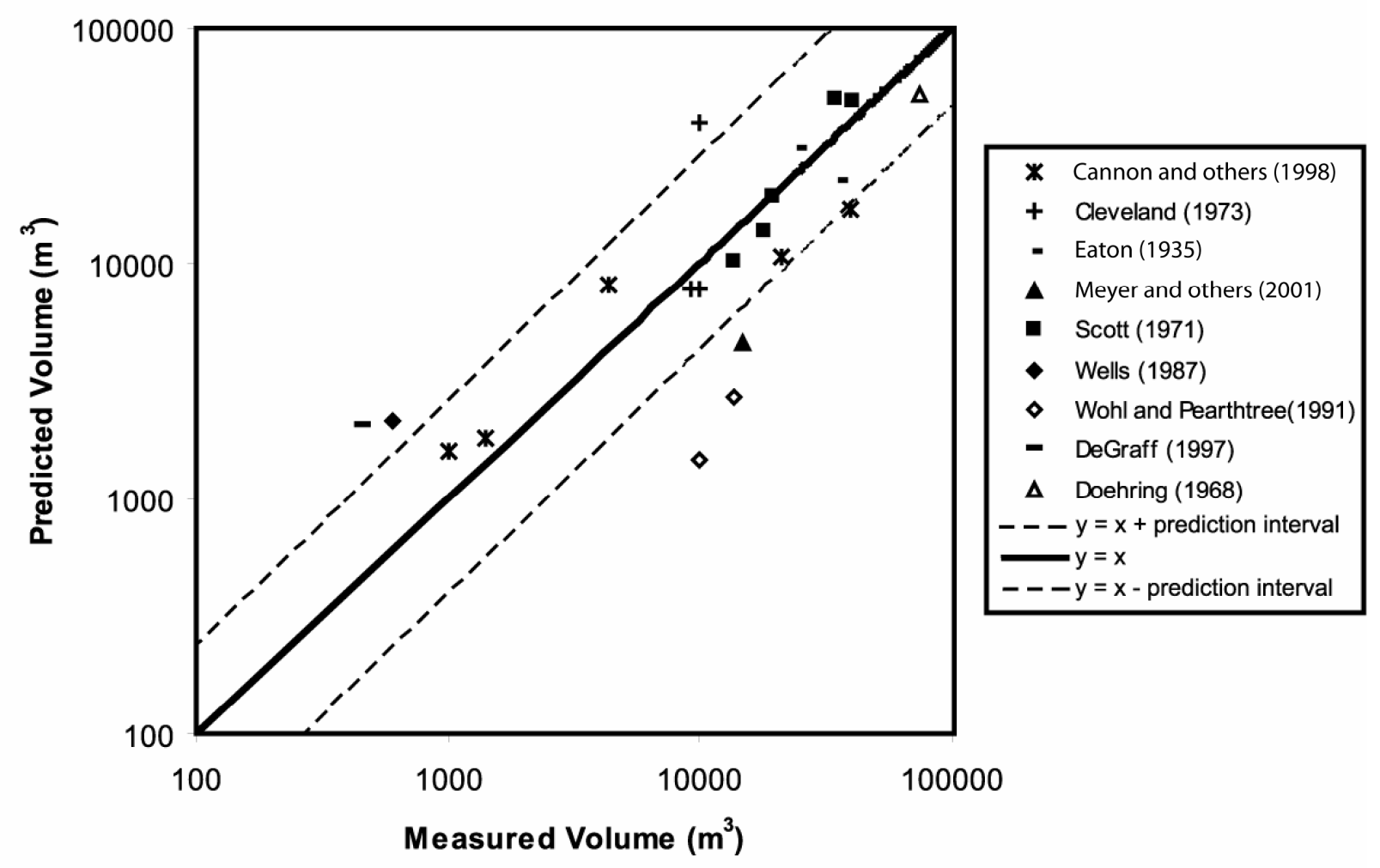

Figure 8. Comparison of debris-flow volume estimates from the literature to predictions of the volume model of Gartner (2005). The solid black line indicates a perfect fit and the dotted lines represent the 68 percent error estimate of the model.

Results from the application of this model to basins in the Missionary Ridge burn area using a 1-hr duration, 25-yr recurrence storm of 1.3 in $(33 \mathrm{~mm})$ are given in figure 9.

Proceed east on CR 252 to CR 250. Turn north on CR 250 and drive about 2.2 miles $(3.5 \mathrm{~km})$ to the Stevens Creek fan. Turn east onto a small dirt road on the north side of the fan and drive about 0.5 mile $(0.8 \mathrm{~km})$ to the east. 


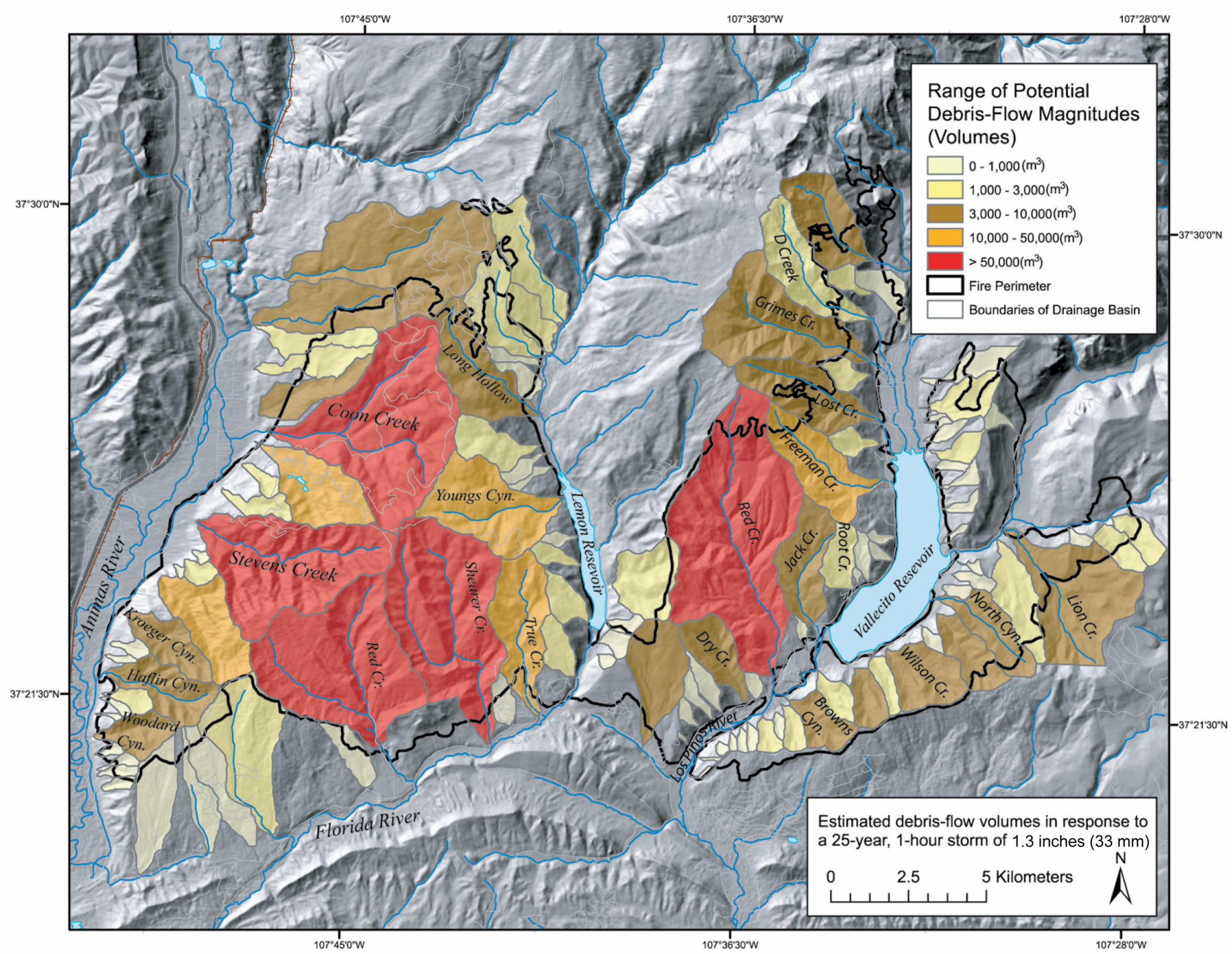

Figure 9. Map showing potential volumes of debris flows from basins in the Missionary Ridge fire burn area for a 1-hr duration, $25 \mathrm{yr}$ recurrence storm of 1.3 in $(33 \mathrm{~mm})$. From J.E. Gartner, unpublished data (2006). 


\section{Stop 2. Debris Flows on Stevens Creek Fan}

GPS location: $\mathrm{N} 37^{\circ} 24^{\prime} 35.0^{\prime \prime} \mathrm{W} 107^{\circ} 48^{\prime} 32.2^{\prime \prime}$ Elevation: 6,791ft (2,070 m). Stop Leaders: Sue Cannon, Jeff Coe, Joe Gartner.

The Stevens Creek fan was burned by the wildfire and then impacted by debris flows several months later. Debris flowed onto the fan on September 7, September 10-12, and September 20, 2002. The September 7 debris flow covered approximately one-quarter of the fan area with deposits as deep as $5 \mathrm{ft}(1.5 \mathrm{~m})$ and filled part of a house with tons of rock and mud (fig. 10). Prior to the debris flow, the house was at least $200 \mathrm{ft}$ $(61 \mathrm{~m})$ from the active channel. During the event, the channel moved from a position on the north side of the house to a position on the south side of the house (fig. 11). The event moved material up to $8 \mathrm{ft}(2.5 \mathrm{~m})$ in diameter in a muddy matrix. Evidence on the fan surface suggested that channels were blocked by large boulders and diverted many times during the event. The current Stevens Creek channel on the fan has been excavated (by excavating equipment) and made deeper and straighter than the natural channel. This excavation provides an excellent longitudinal exposure of Holocene fan deposits (fig. 12). Upstream from the fan, the channels showed up to $8 \mathrm{ft}(2.5 \mathrm{~m})$ of incision into extensive valley-fill deposits.

Debris flows produced by the September 10-12 and September 20 rainstorms were smaller discharge events carrying smaller (up to cobble-sized) material than those of September 7. Soil-slip scars that formed during these storms were observed in the upper reaches of Stevens Creek. These scars were relatively small—at most $100 \mathrm{ft}^{2}\left(10 \mathrm{~m}^{2}\right)$ in area — and were produced when hillslope material mobilized into debris flows that traveled a few hundred feet down the hillslopes on which they originated.

Two primary processes for the initiation of debris flows were identified in the Missionary Ridge burned area: runoff-dominated erosion by surface overland flow, and infiltration-triggered failure and mobilization of discrete landslide masses. Debris flows generated through runoff and erosion occurred in response to short-duration, highintensity storms (and are thus the most frequent), while landslide-triggered debris flows were observed following a long-duration (multi-day), low-intensity storm.

Debris-flow initiation in recently burned areas is most frequently attributed to significantly increased rates of rainfall runoff. In the Missionary Ridge fire, Cannon and others (2003a) observed that runoff high on hillslopes resulted in the generation of rills. Convergence and concentration of flow within hollows and in low-order channels resulted in considerable erosion, often to bedrock, and the transport of material downslope. Debris-flow deposits first occurred in the lower reaches of the drainage networks. The debris flows appeared to initiate through progressive bulking of surface runoff with sediment entrained by rill erosion in steep, upper-basin slopes and from deep incision as the flows progressed down channels. The sheer volume of material that was excavated from the drainage network suggests that a large proportion of the material within the debris flows originated from the channel. 

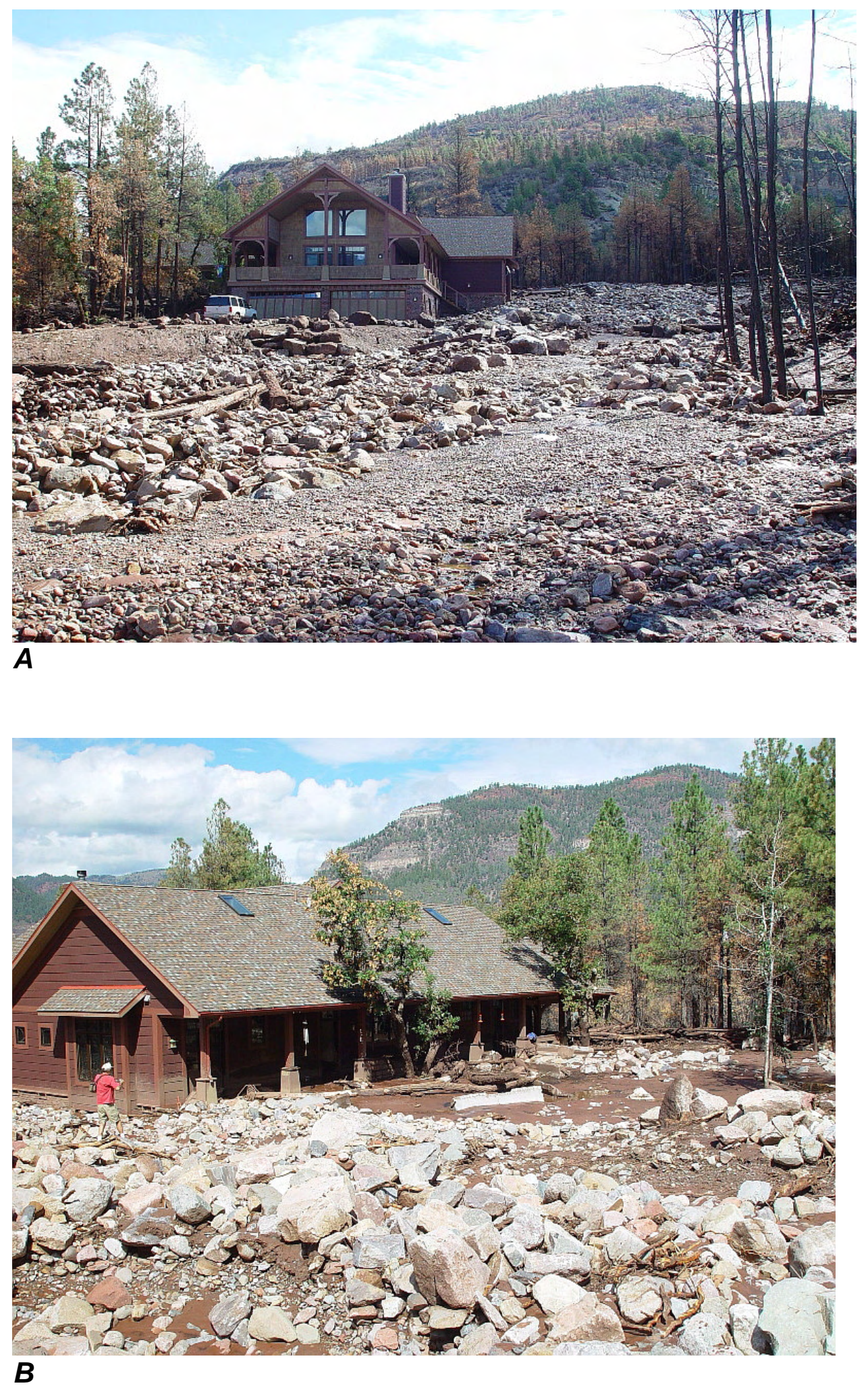

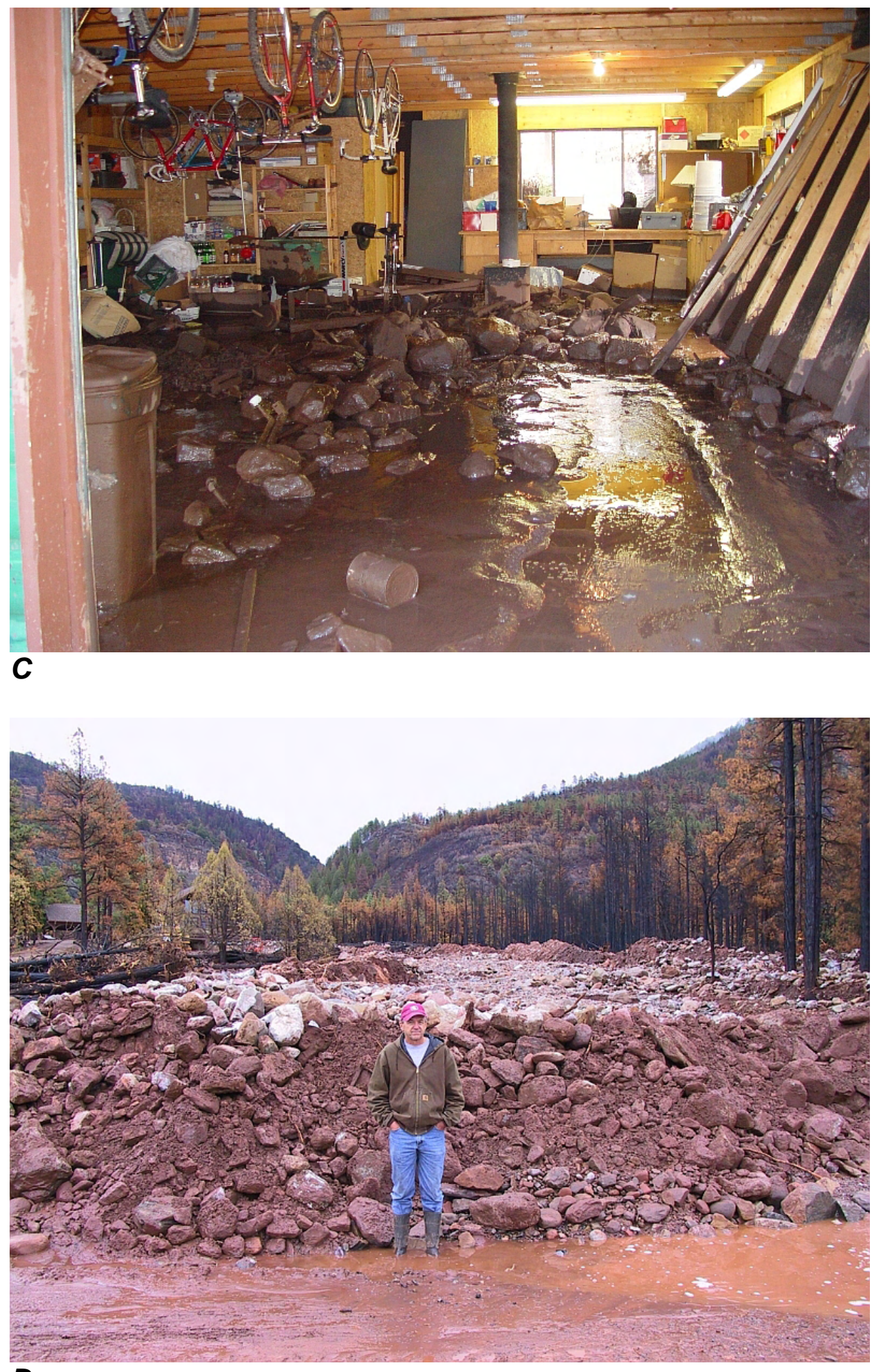

D

Figure 10. Debris-flow deposits on the Stevens Creek fan caused by the September 7, 2002, rainstorm. $A-C$, Deposits in and near residence on central part of fan; $D$, Deposits in channel near County Road 250. Photographs courtesy of La Plata County. 


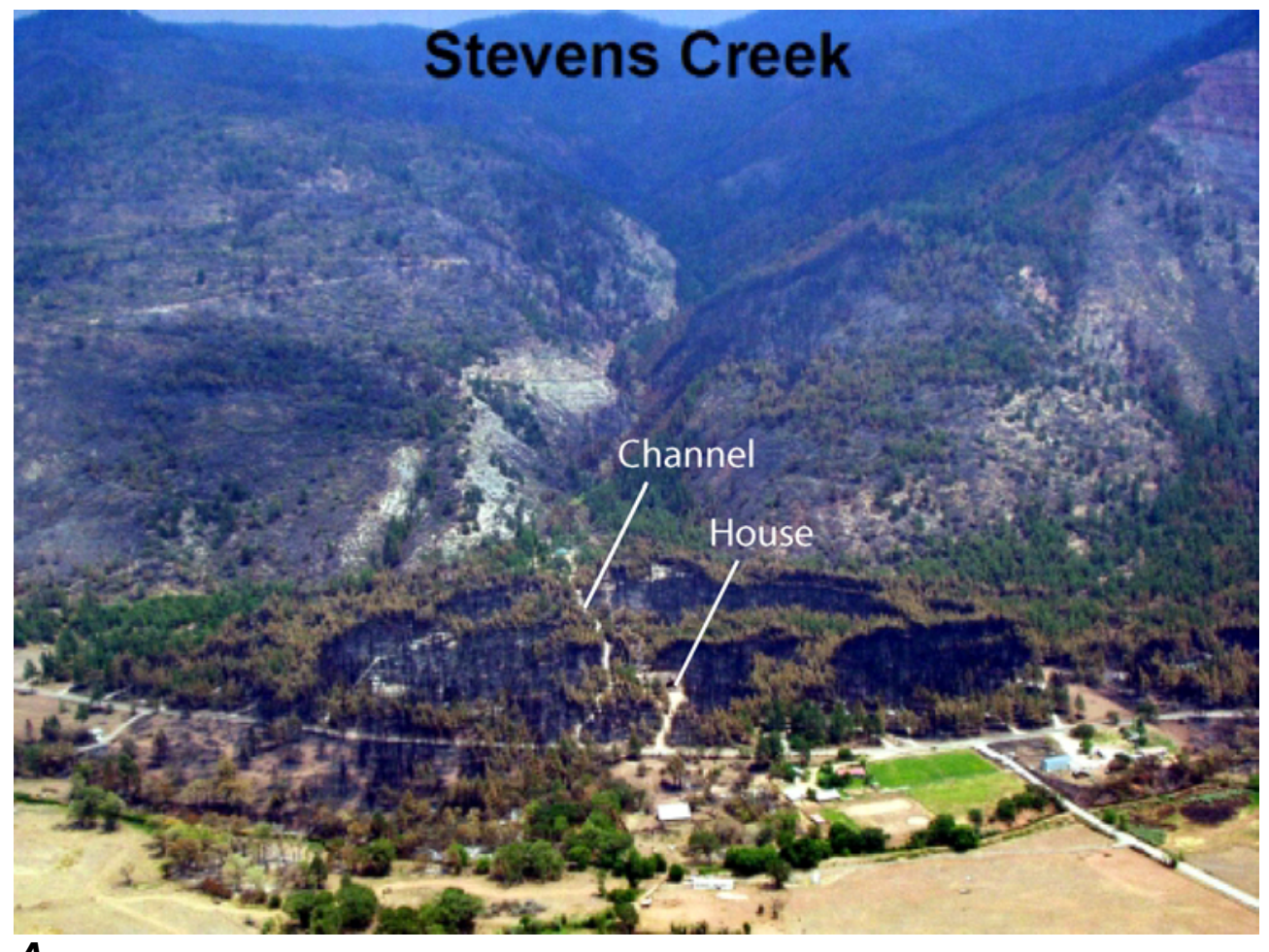

\section{$\boldsymbol{A}$}

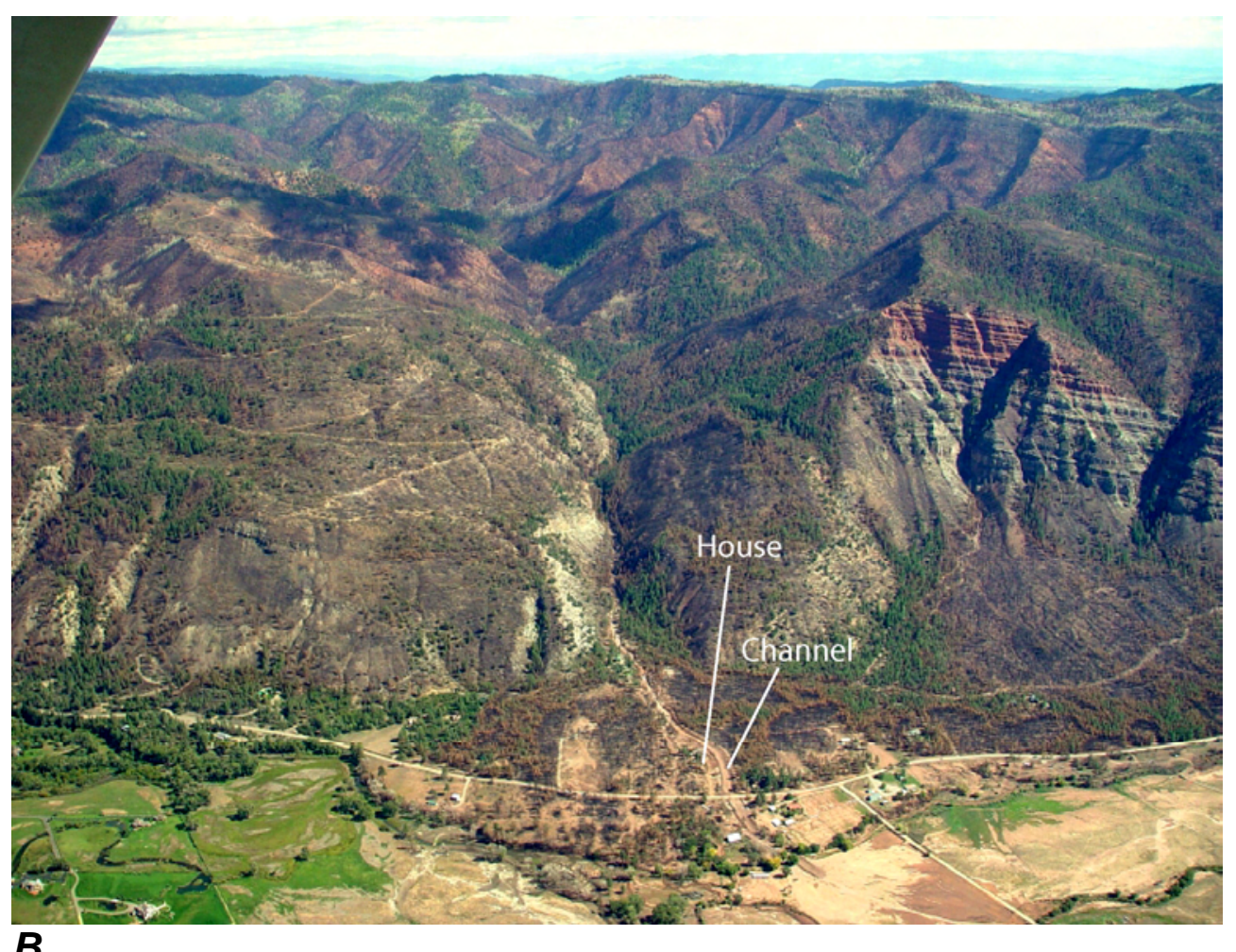

Figure 11. Photographs showing channel migration on the Stevens Creek fan. A, Predebris flow channel location; $B$, Post-debris flow channel location. Photographs courtesy of La Plata County. 

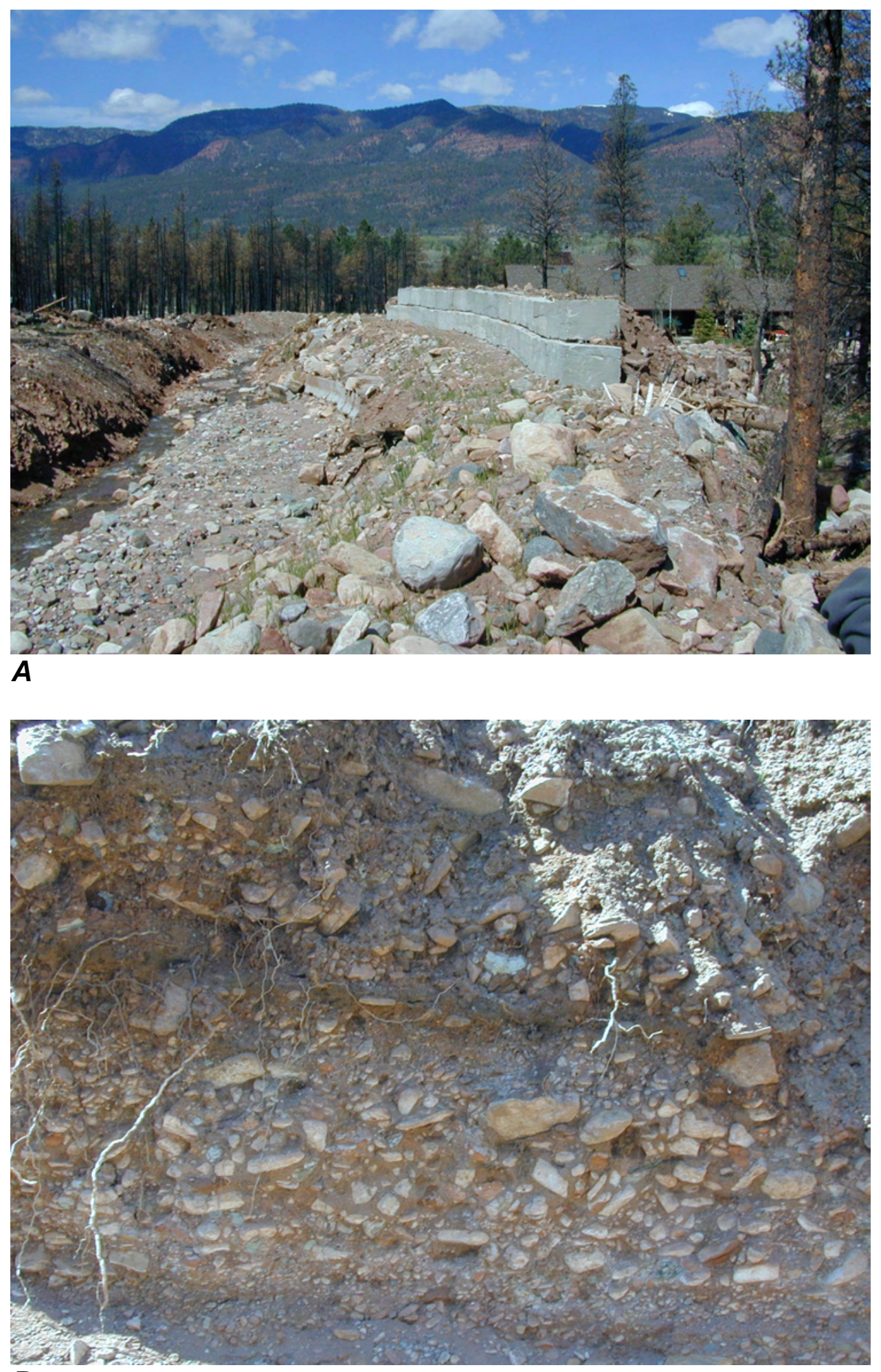

B

Figure 12. Debris-flow channel on the Stevens Creek fan. A, Excavated channel and barrier; $B$, Holocene debris-flow deposits exposed on the south side of the channel. 
Return to CR 250 and proceed south about 3.6 miles $(5.8 \mathrm{~km})$ to the trail head on the north side of the Haflin Creek fan. Walk up the trail to the Haflin Creek channel.

\section{Stop 3. Debris Flows on Haflin Creek Fan}

GPS location: N 37²2’02.0” W $107^{\circ}$ 50’ 25.0” Elevation: 6,620 ft. (2,018 m). Stop Leaders: Joe Gartner and Butch Knowlton.

The entire Haflin Creek drainage basin was burned by the fire (figs. 13 and 14) and then impacted by debris flows several months later. As described at the last stop, debris flows were generated by rilling and erosion of channel materials (figs. 15-18) and impacted structures and CR 250 on the fan at the mouth of the drainage (fig. 19). Two storms generated the debris flows, one on August 29 and the other on September 20, 2002. The August 29 debris flows carried material no greater than $3 \mathrm{ft}(1 \mathrm{~m})$ in diameter in a muddy matrix. The September 20 debris flows carried materials only up to about 1.5 $\mathrm{ft}(0.5 \mathrm{~m})$ in diameter, a significant decrease in size from the August event.

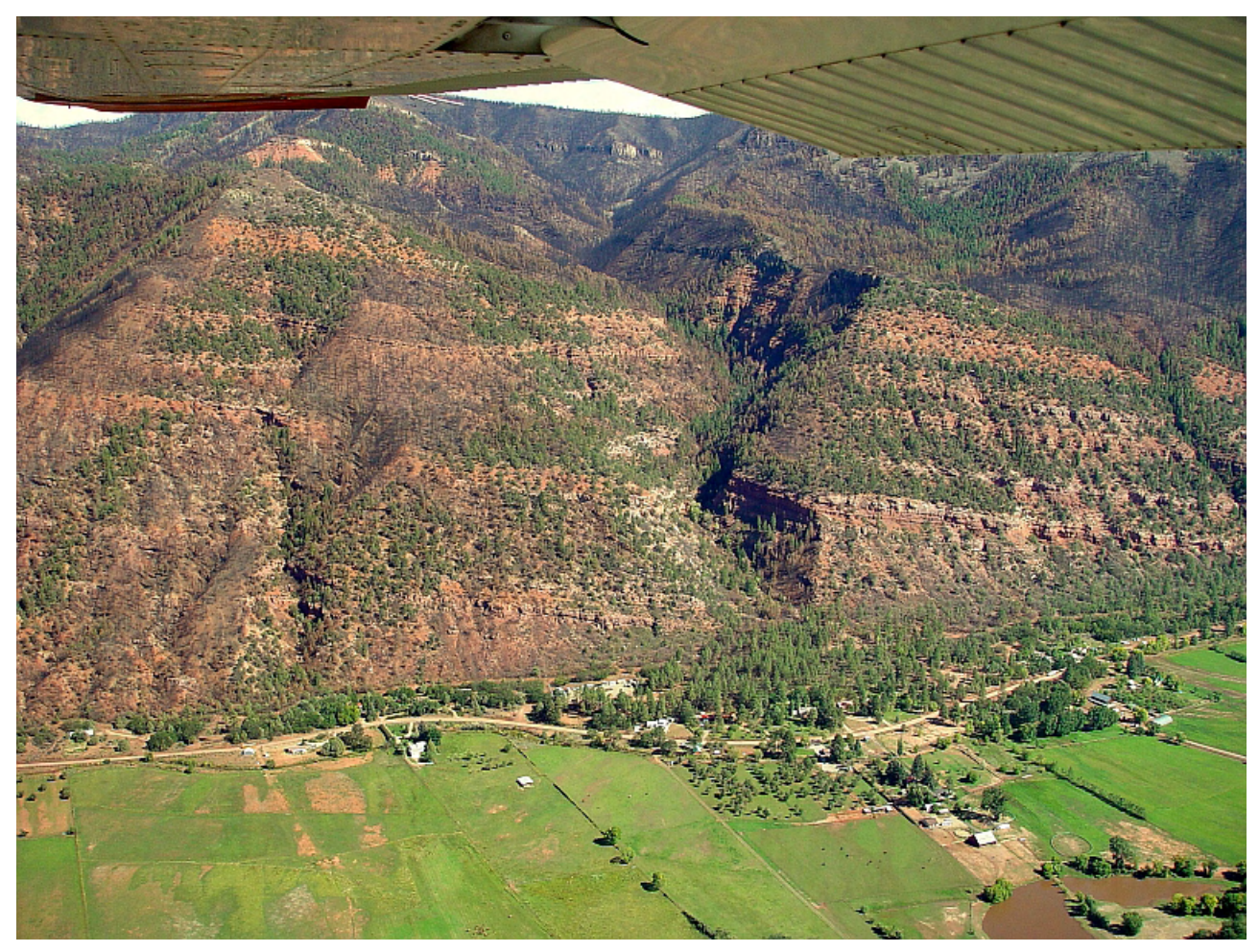

Figure 13. Haflin Creek drainage basin and fan. Photograph courtesy of La Plata County. 

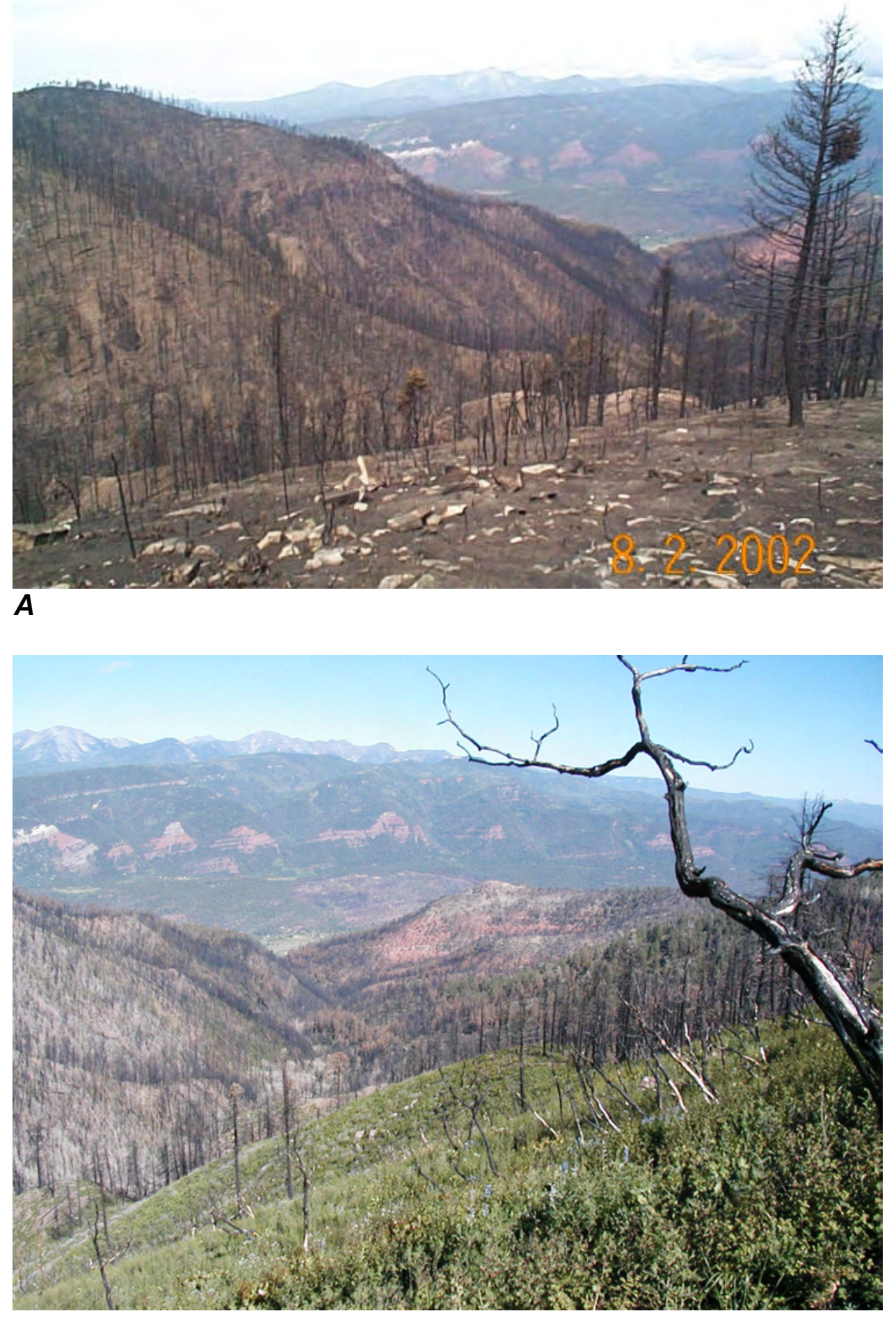

B

Figure 14. Mountainside near the head of the Haflin Creek drainage basin. A, About 1 month after the fire was extinguished; $B$, About $1 \mathrm{yr}$ after the fire. Photographs courtesy of La Plata County. 


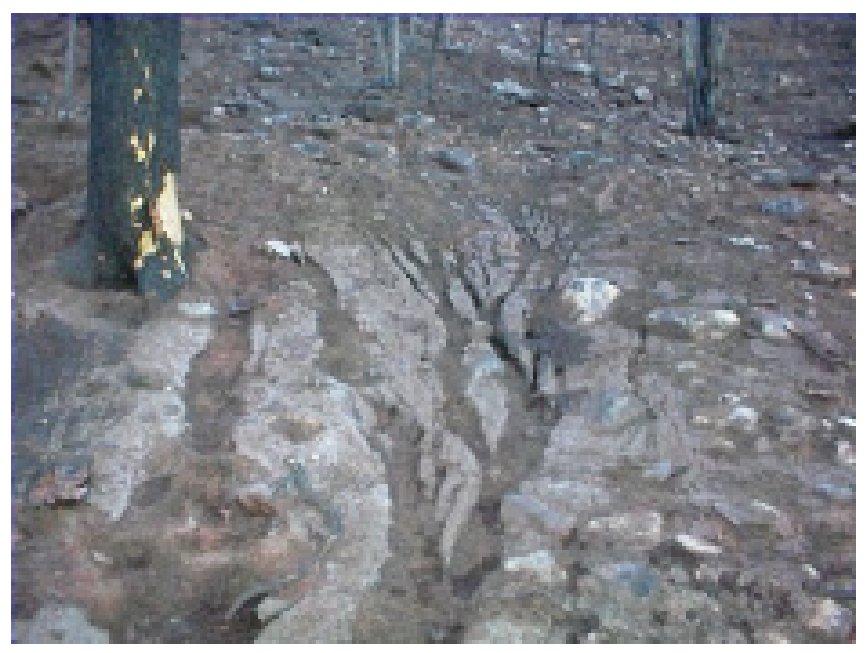

Figure 15. Rills in the Haflin Creek drainage basin. Photograph courtesy of La Plata County.

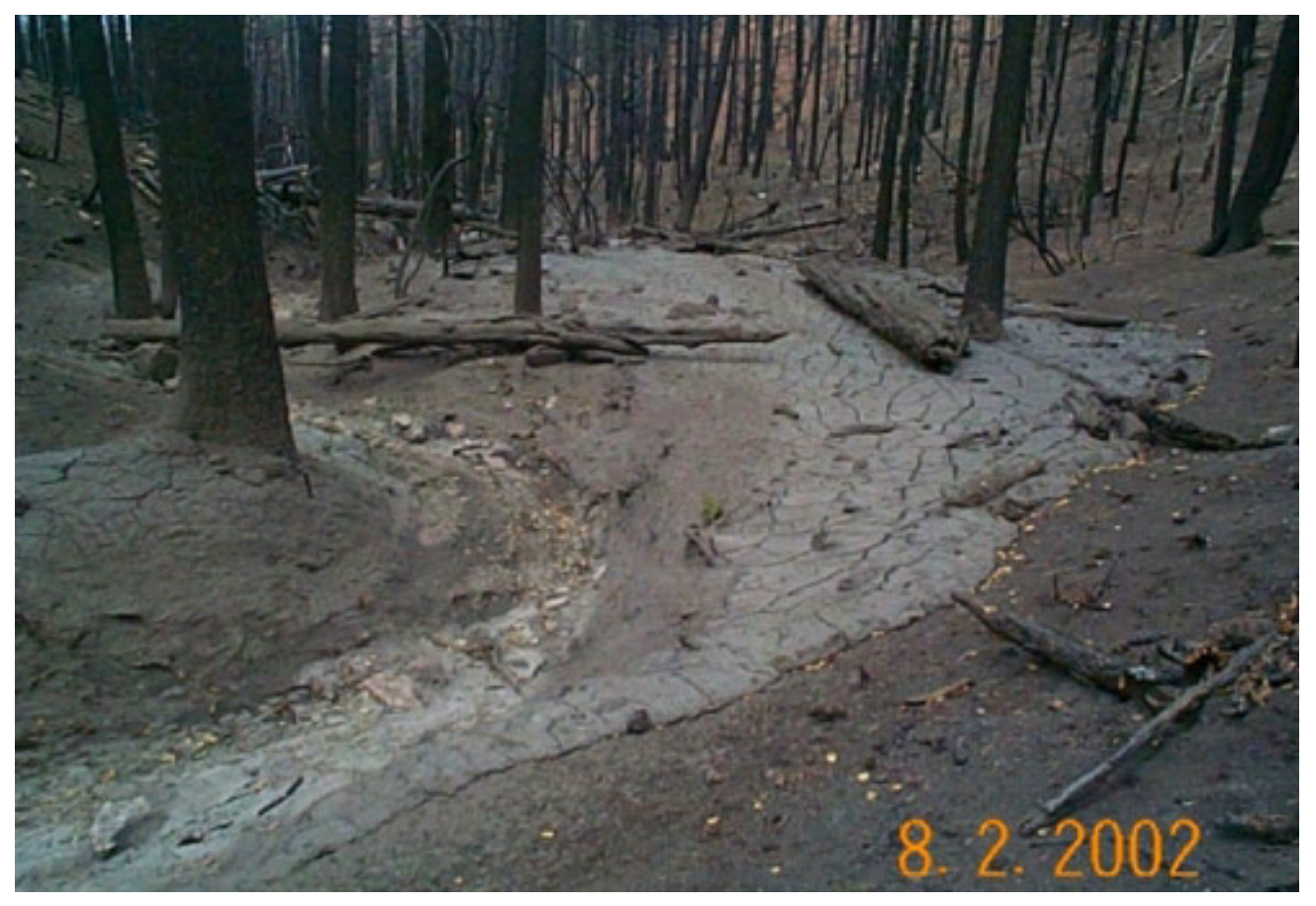

Figure 16. Ash/mud flow deposit in the Haflin Creek drainage basin. Photograph courtesy of La Plata County. 


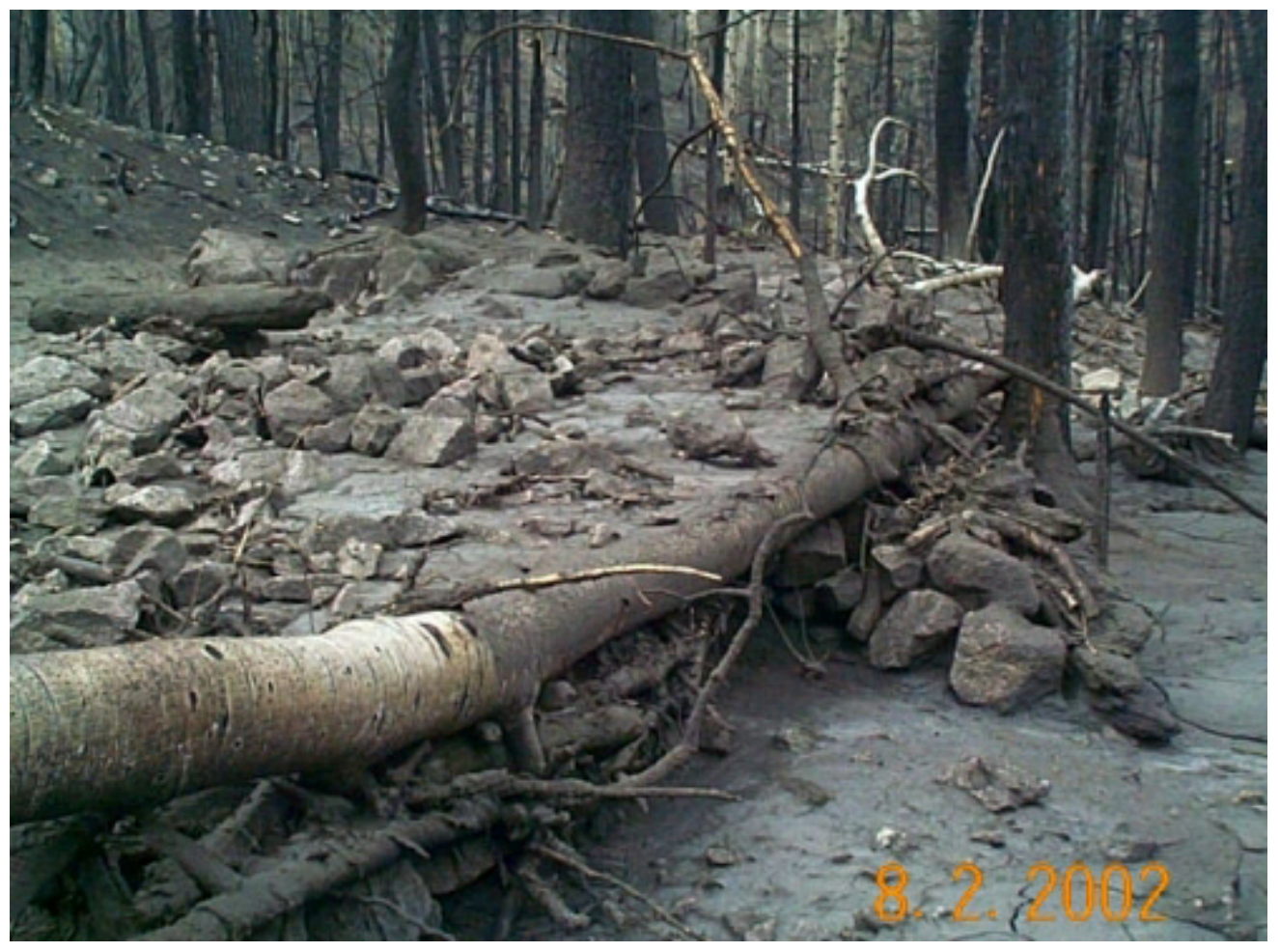

Figure 17. Debris-flow deposits in the Haflin Creek drainage basin. Photograph courtesy of La Plata County. 


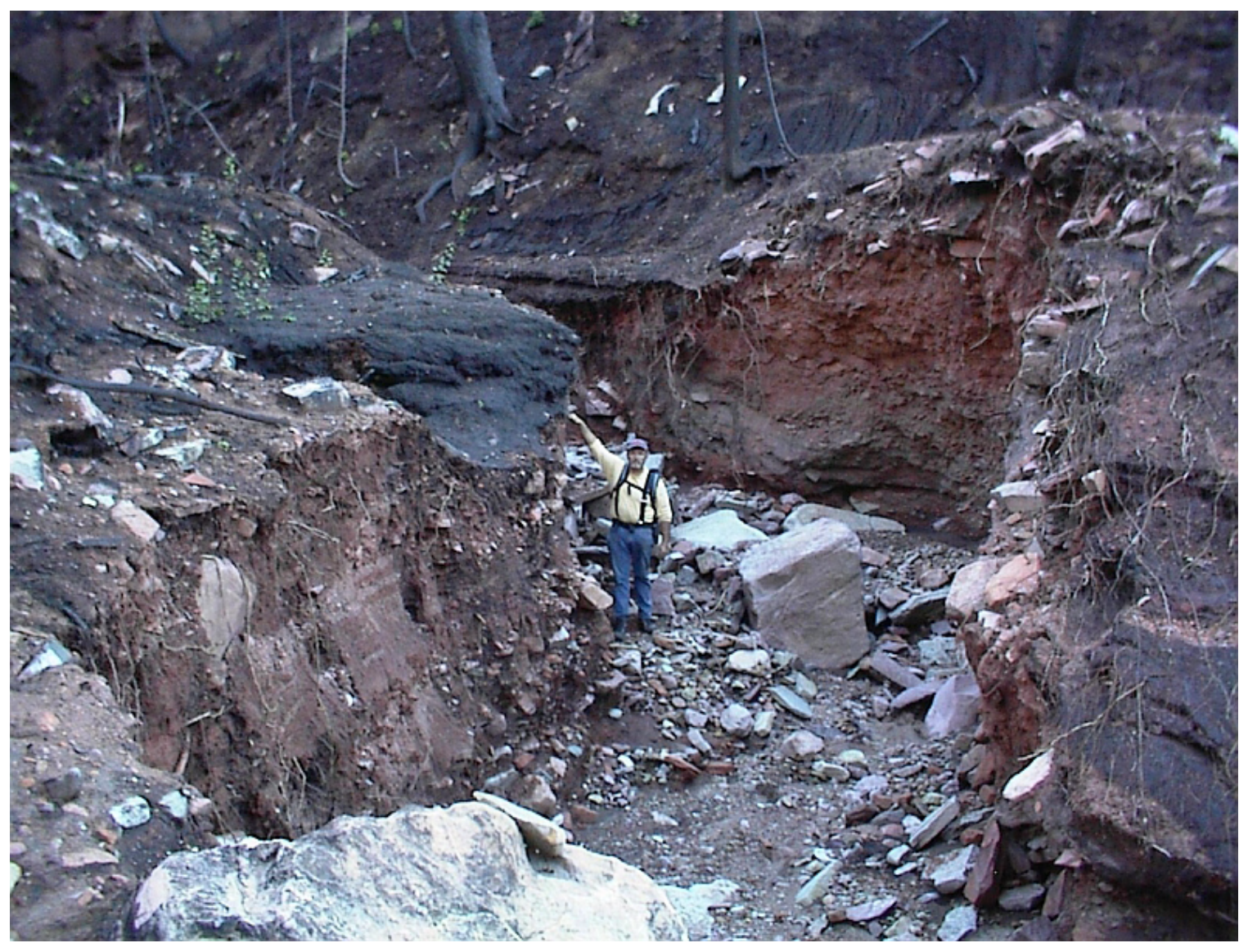

Figure 18. Channel incision in the Haflin Creek drainage basin. Photograph courtesy of La Plata County.

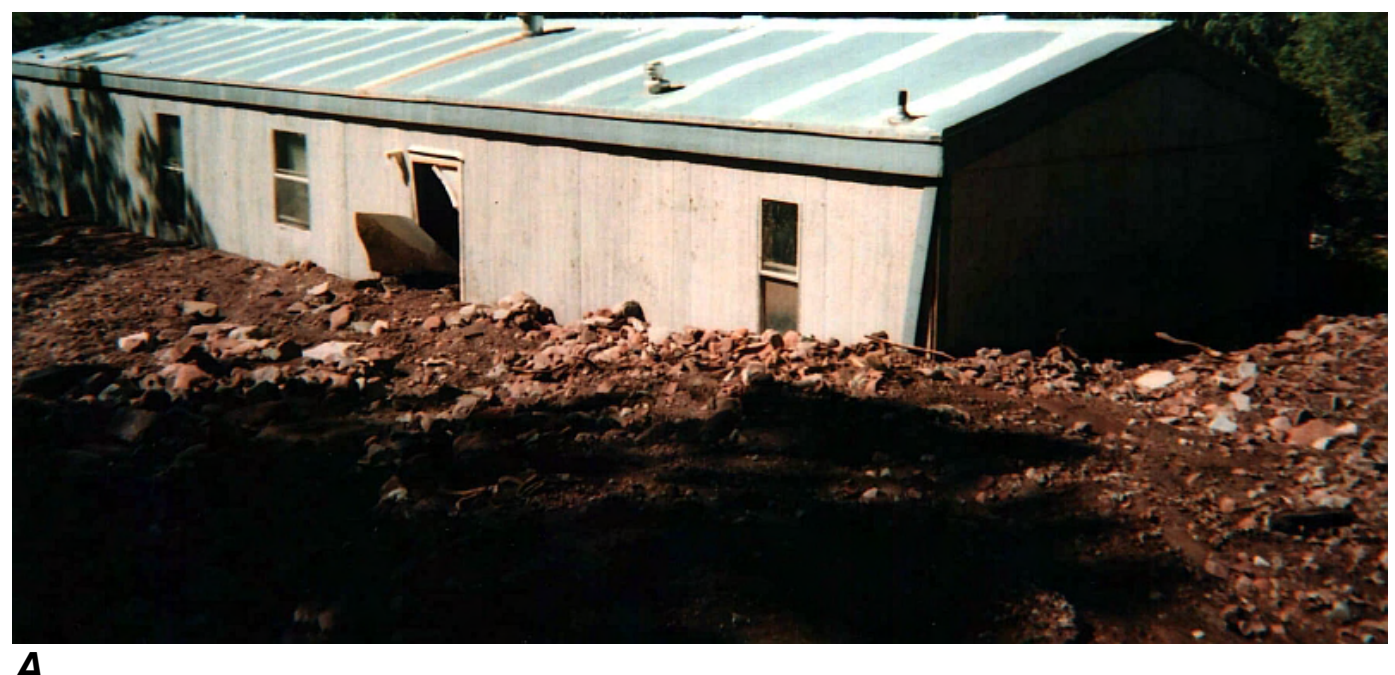




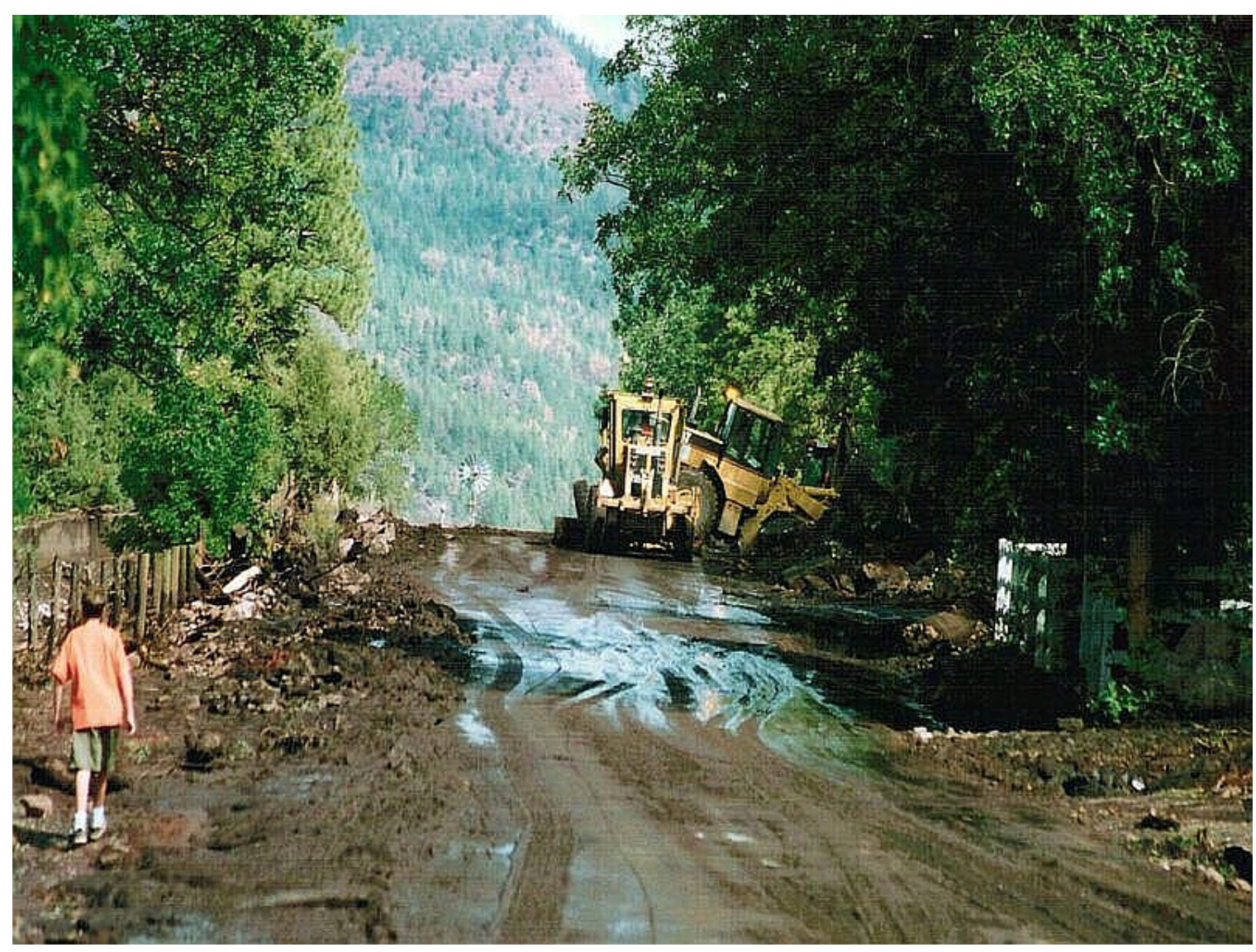

B

Figure 19. Damage from debris flows on the Haflin Creek fan. A, Structure impacted by debris flow; $B$, Debris-flow deposits on County Road 250. Photographs courtesy of La Plata County.

The Haflin Creek channel is also an excellent location to demonstrate the method used by Gartner (2005) to estimate the material eroded from channels by debris flows. Recall that to generate the statistical model used to predict potential debris-flow volumes generated from burned basins, debris-flow volumes from 56 events were estimated by quantifying the amount of material eroded from the main channels of a basin by the passage of a debris flow. Channel cross sections were measured at 50- to 300-ft (15- to 91-m) intervals along the length of the scoured channel using a 1-yd (1-m) length of lumber with legs and an inclinometer attached to measure the slope of the ground surface. The device was used to record angles across the surface of a channel to quickly measure a channel cross section. For each cross section, notes were taken to identify which measurements correspond to incised channel, bedrock, and(or) levees. These notes helped to interpolate the original channel surface and determine the amount of material removed from each cross section. Scoured areas of adjacent cross sections were averaged and multiplied by the distance between them to define a volume of material scoured by the debris flow. The sum of all segments of scoured channel represents the total estimated volume of material eroded from the channel and corresponds to the amount of material deposited at the mouth of the basin. 
The predictive peak discharge and volume maps for the 25-yr recurrence storm (figs. 7 and 9) indicate that Haflin Creek should have a smaller debris-flow response than Stevens Creek. The peak-discharge model estimates a value of approximately $8,000 \mathrm{ft}^{3} / \mathrm{s}$ $\left(230 \mathrm{~m}^{3}\right)$, and the volume model estimates a yield of approximately $12,800 \mathrm{yd}^{3}\left(9,750 \mathrm{~m}^{3}\right)$ in response to 1.3 in $(33 \mathrm{~mm})$ of rain in $1 \mathrm{hr}$. None of the storms to impact the area after the fire approached this recurrence level, so comparisons of actual and predicted values are not possible.

Return to CR 250 and proceed south to CR 240. Turn west on CR 240, then south on North College Drive. Turn right on Rim Drive. Stop 4 (lunch) is at the Lions Den Picnic Shelter on the right hand side of Rim Drive.

\section{Stop 4. Lions Den Picnic Shelter}

Lunch. Overview of Lower Animas Valley, Fort Lewis College Mesa. GPS location: N $37^{\circ} 17$ ' 17.5” W $107^{\circ}$ 51' 41.3" Elevation: 6,970 ft. (2,124 m). Stop Leaders: Rob Blair and Mary Gillam.

The Lions Den Shelter is located at the northern edge of the Fort Lewis College Mesa at an elevation of about 6,970 ft (2,124 m). It provides stunning views of the lower Animas Valley (fig. 20) to the north and the La Plata Mountains to the west. On the horizon to the north up the valley one can just make out peaks making up the Twilight Gneiss (1,780 Ma), the oldest rocks seen from this vantage. It is clearly evident from the dipping Paleozoic and Mesozoic strata that are exposed in the valley walls that as one travels north one travels back into geologic time (fig. 4).

Animas City Mountain, located northwest of Durango, displays 5- to 7-degree dip slopes of the late Cretaceous Dakota Sandstone and is expressed as westward tilted rim rock. Below the Dakota, the Jurassic Morrison Formation makes up the lightly forested slopes. This is followed by the whitish cliffs of the Junction Creek Sandstone, the Wanaka Formation, and the lower whitish cliffs of the Entrada Sandstone, all Jurassic in age. Looking upvalley, the thin pinkish red rocks below the Entrada are probably the most eastern remnants of the Late Triassic Wingate Sandstone that overlay the Dolores Formation and the reddish Permian Cutler Formation (Blair, 1996).

To the west of Durango, the grey Mancos Shale dominates the landscape. Local geologic lore suggests that most of the particulates (maybe up to 80 percent) of the Mancos Shale have passed through the bowels of some organisms. This shale underlies the Lions Den Shelter and makes up the slopes rising to the hogback rim immediately to the east of the Shelter. The Point Lookout Sandstone (eastern horizon) forms the Hogback monoclinal flexure and marks the approximate boundary between the Colorado Plateau to the west and the Southern Rocky Mountains to the east.

The La Plata Mountains (Silver Mountains in English) to the west are the erosional remnants of a structural dome uplifted from the injection of magma into the overlying Phanerozoic strata (65 Ma ago). The exposed rocks reveal a complex labyrinth of anastomosing sills, dikes, laccoliths, pipes, and sedimentary layers (Blair, 1996, p. 339). 


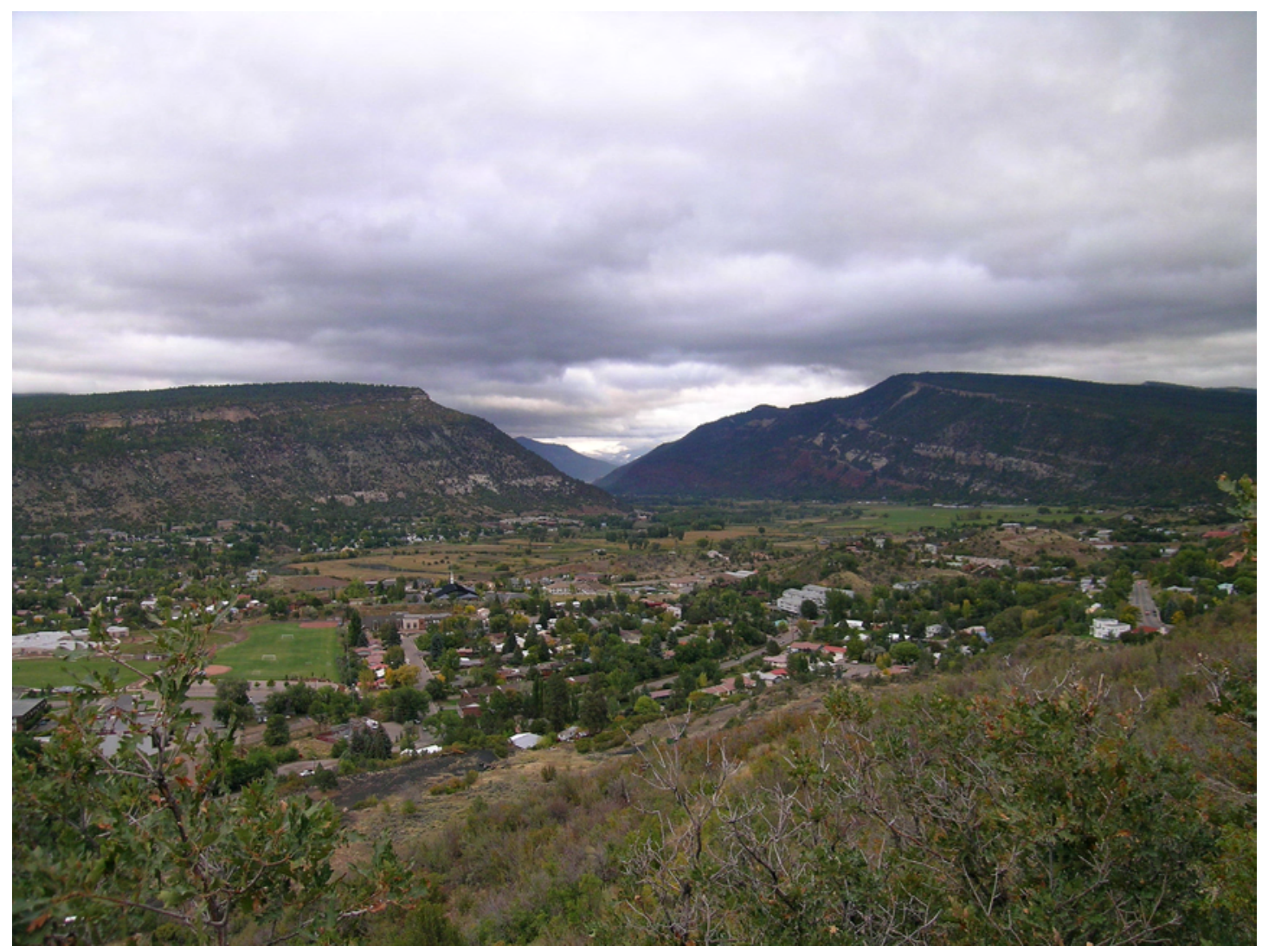

Figure 20. View of the lower Animas Valley to the north, from the Lions Den Picnic Shelter in Durango.

The lower Animas Valley is a glacial valley made flat by stream and lake sediment. The gravel hill upon which the Lyons Shelter is built and the ridges seen between the shelter and the flat floor of the valley are glacial end moraines. At the time of the melting and retreat of Pleistocene glaciers, "Lake Durango" formed. It was, however, quickly filled to capacity with fine sediment and gravel, the height of which was controlled in part by the height of moraines and the base of the Dakota Sandstone. Current age estimates for the moraines are shown in table 1 . The outwash terrace (approx. $250 \mathrm{ka}$ ) seen to the south of the Lions Den Shelter is now the site of a golf course. 


\begin{tabular}{lll}
\hline \multicolumn{1}{c}{ Moraine } & \multicolumn{1}{c}{ Age (ka) } & \multicolumn{1}{c}{ Basis } \\
\hline Bakers Bridge & $\geq 17.1 \pm 1.2$ (nuclide) & $\begin{array}{l}{ }^{10} \mathrm{Be} \text { on ice-scoured granite } \\
\text { (one) }\end{array}$ \\
Animas City 3 and 2 & $>17$-approx. 21 (nuclide) & $\begin{array}{l}{ }^{36} \mathrm{Cl} \text {, Rio Grande area; }{ }^{10} \mathrm{Be} \\
\text { on terrace (one) }\end{array}$ \\
Animas City 1 & Approx. 22-<60 & $\begin{array}{l}\text { Regional correlation } \\
\text { Optically Stimulated }\end{array}$ \\
Spring Creek 2 & $<61+12 /-11$ (?) & $\begin{array}{l}\text { Luminescence (two, see } \\
\text { note below) }\end{array}$ \\
Spring Creek 1 & Approx. 130-190 & $\begin{array}{l}\text { Regional correlation } \\
\text { Long-term river incision } \\
\text { and Lava Creek B ash }\end{array}$ \\
& Approx. 250-275 & $\begin{array}{l}\text { Long-term river incision } \\
\text { and Lava Creek B ash }\end{array}$ \\
Durango 1 & Approx. 345-360 &
\end{tabular}

Table 1. Ages of Lower Animas Valley glacial moraines. Note: Dates on one outcrop of Spring Creek 2 may not apply to all deposits now assigned to that unit (the deposits are very poorly preserved, so they could have formed as parts of more than one moraine between Spring Creek 1 and Animas City 1). Summary by Gillam, 1998; Pierce, 2003; Applegate, 2005; Benson and others, 2005; Z. Guido, written communication, 2006.

During the spring meltoff of winter snow, the Animas River will usually flood the lower valley. The oxbows fill first, then spill over to form a large shallow lake. As one travels north up the Animas Valley, note the relative abundance of alluvial fans on the east side compared to the west. This topographic asymmetry is due to the influence of Hidden Creek, which forms a small "perched" valley found parallel to and west of the Animas Valley. Its origin is debatable but is tied to events during the last glacial maxima. This valley intercepts eastward-heading drainages and prevents fans from building along the west side of the Animas Valley. In contrast, the drainages flowing westward from the eastern cliffs are associated with debris fans. These drainages flood every 5-10 yrs, much to the consternation of the County highway department, which has to close East Animas Road (CR 250) and clear the debris. The Missionary Ridge fire during the summer of 2002 burned on the eastern slopes of the Animas Valley and temporarily increased the frequency and volume of debris-flow events.

Very little debris from the Missionary Ridge fire has reached the Animas River. During late Holocene time, the valley floor has aggraded very slowly with sediment from the upper Animas drainage and local tributary streams. However, since the early 1970s, in-stream gravel mining has caused the channel to incise in several places by as much as 13-30 ft (4-9 m) (M. Gillam, unpub. data obtained from several sources).

Return to CR 240 and proceed east to the junction with CR243. Follow CR243 north to Lemon Dam. Turn left onto the dam and drive across. Stop 5 is at the west end of Lemon Dam. 


\section{Stop 5. Debris Flow Mitigation at Knight Canyon and Landslides along the Florida River.}

West end of Lemon Reservoir dam. GPS Location: N 37²1' 53.7' W 107 39' 06.6" Elevation: 8,630 ft (2,630 m). Stop Leaders for Knight Canyon: Paul Santi and John Ey. Stop Leaders for Florida River landslides: Bill Schulz and John Ey.

\section{Knight Canyon at Lemon Dam}

Lemon Dam is a critical part of the water supply system for the City of Durango. Therefore, erosion of sediment and(or) debris flows into the reservoir following the 2002 Missionary Ridge fire could have had severe consequences. The Florida Water Conservancy District (FWCD) was given the resources and the mission to prevent significant sediment movement into critical portions of the reservoir. They concentrated their efforts on the drainage basin known as Knight Canyon, which empties near the intake structure for the water supply system (fig. 21). The mitigation efforts carried out by the FWCD consisted of construction of Log Erosion Barriers (LEBs), mulching, seeding, and construction of check dams and debris racks (deWolfe and others, 2005), as summarized in tables 2 and 3. These methods were effective in virtually eliminating sedimentation into the reservoir. This success can be attributed to a number of factors: the density of application of each mitigation method, the enhancement of methods working in concert, the quality of installation, and the rehabilitation of mitigation features to extend their useful life. The application of each method is summarized below.

\section{Log Erosion Barriers}

Log Erosion Barriers (LEBs) serve as small hillside check dams to disrupt overland flow, enhance infiltration, and capture eroded sediment. A typical layout pattern for LEBs is shown in figures 22 and 23. Some technical studies indicate that LEBs are inconsistent in their ability to reduce erosion and that they are ineffective during heavy rains (Gartner, 2003; Wohlgemuth and others, 2001; Robichaud, 2005). However, the LEBs at Lemon Dam appeared to have reduced hillslope erosion and enhanced runoff infiltration because they were applied in heavy concentrations and with other erosion control measures. At Lemon Dam, 231 acres (93 ha) of a severely burned basin above the dam's spillway and intake structures were treated with concentrations between 90 and 250 LEBs/acre (223-619 LEBs/ha) and rehabilitated multiple times after being filled by the runoff accompanying heavy rainfall (John Ey, personal commun., 2004). Rehabilitation consisted of removing accumulated debris from the upslope side of the LEB and placing the removed debris on the downslope side of the LEB. LEBs are usually applied to large areas in National Forests in concentrations of 40 LEBs/acre (99 LEBs/ha, Burn Area Emergency Rehabilitation Team, 2002).

LEB installation is difficult and expensive, which limits the size of an area on which LEBs can be installed. For example, about \$1.38 million were spent on LEB installation on only 4,626 acres (1,872 ha) of the 73,000 acres (29,500 ha) burned by the Missionary Ridge fire (Burn Area Emergency Rehabilitation Team, 2002). 


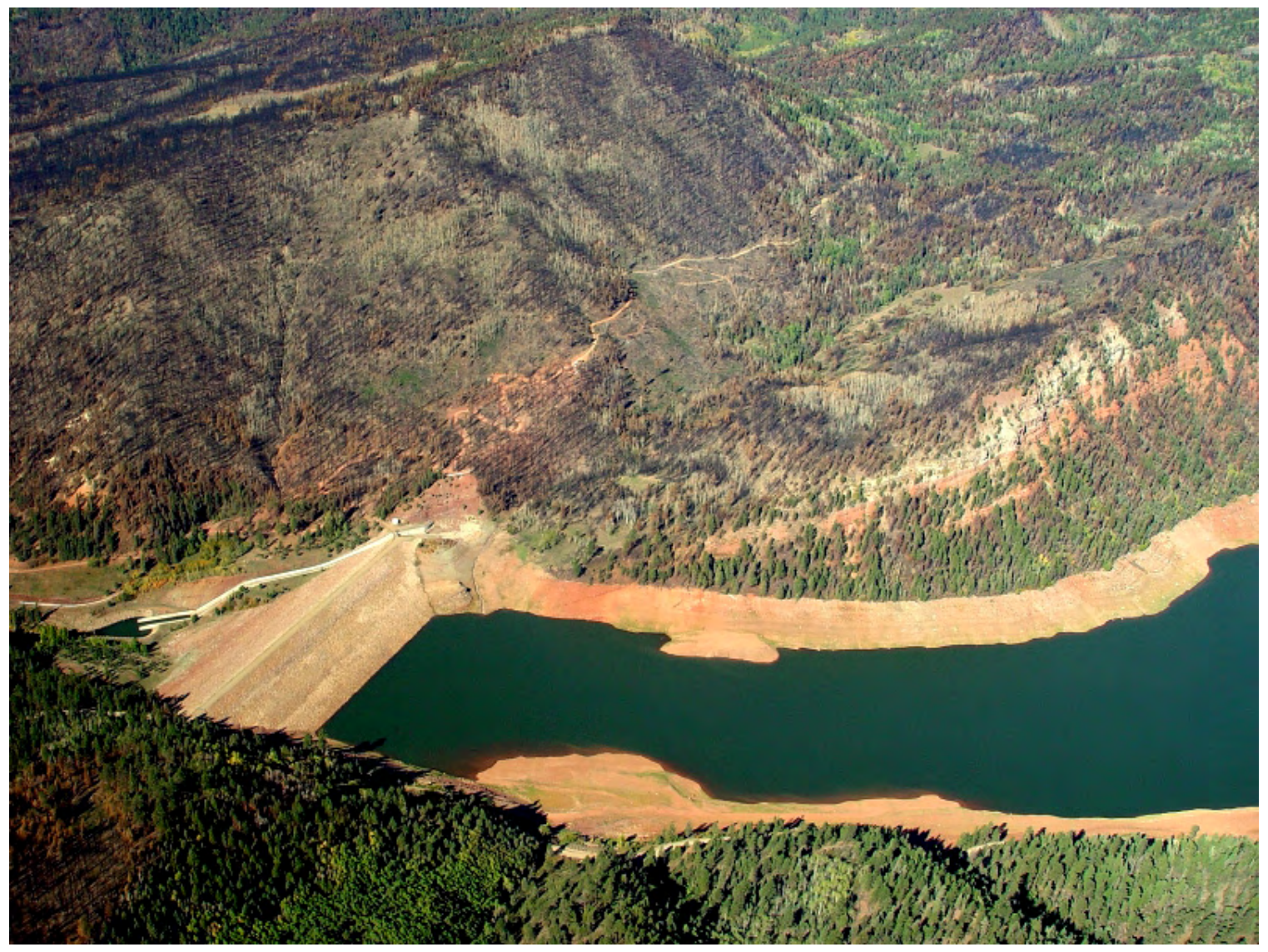

Figure 21. Knight Canyon (upper center/right side of photograph) above the spillway intake at Lemon Dam. Photograph courtesy of La Plata County.

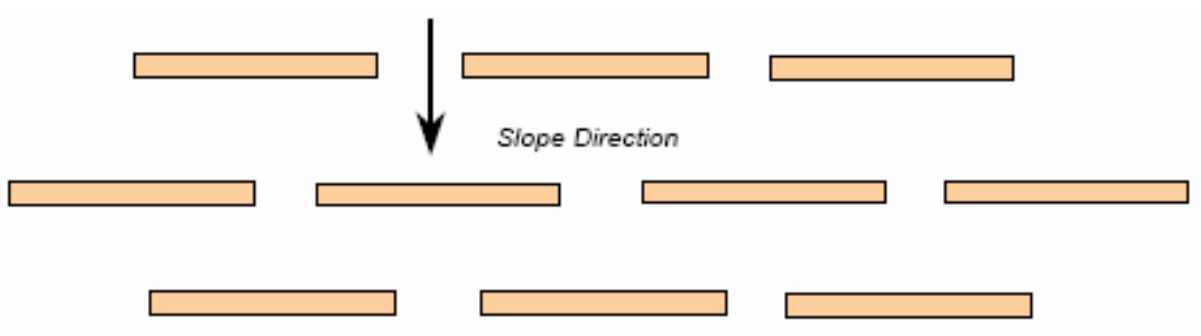

Figure 22. Staggered pattern in which log erosion barriers should be placed on a slope. 


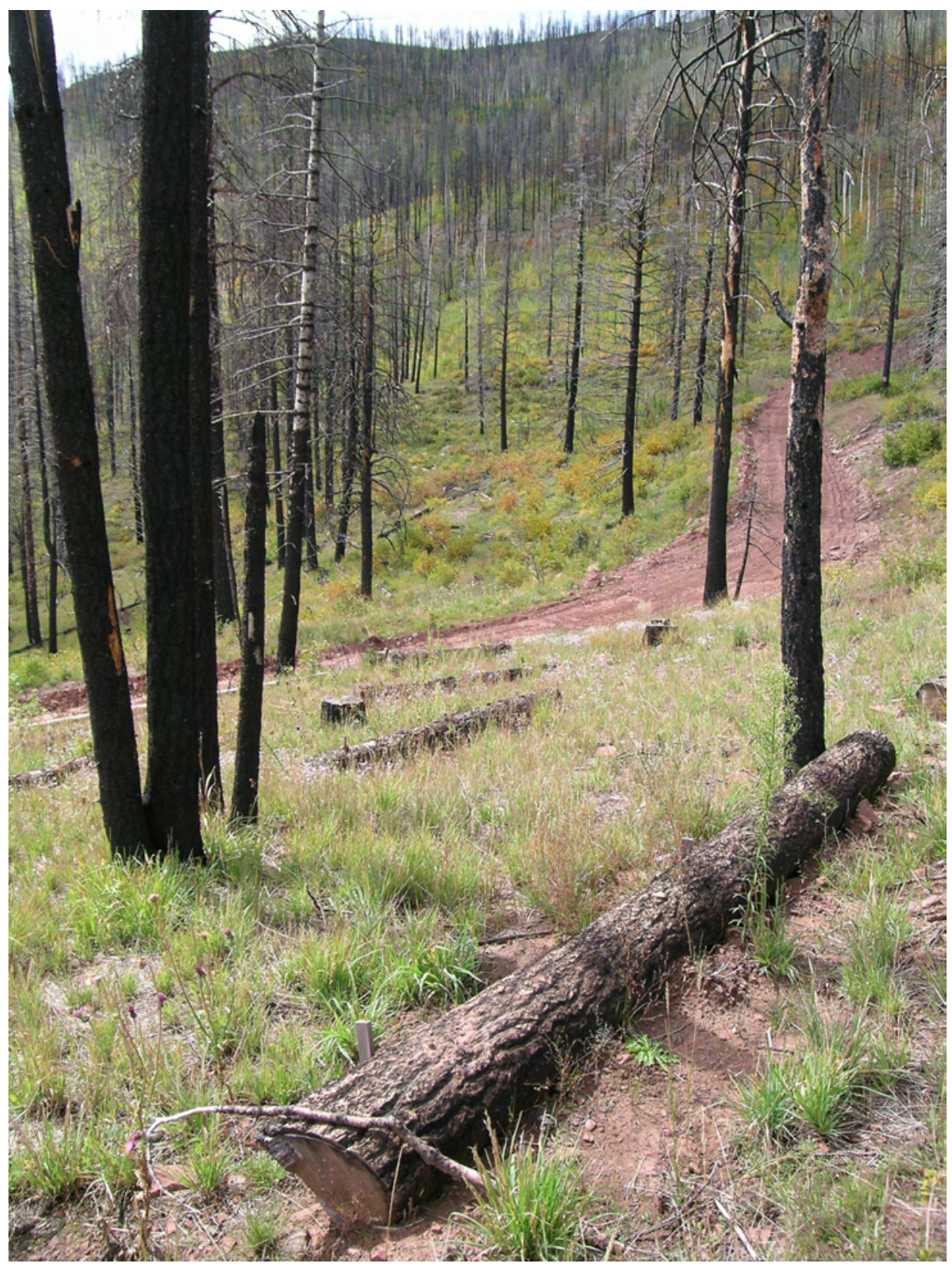

Figure 23. Log erosion barriers near Lemon Dam following the Missionary Ridge fire. 


\begin{tabular}{|l|c|c|c|c|}
\hline \multicolumn{1}{|c|}{ Event } & $\begin{array}{c}\text { Number or } \\
\text { Concentration }\end{array}$ & $\begin{array}{c}\text { Area } \\
\text { Treated }\end{array}$ & $\begin{array}{c}\text { Treated Slope } \\
\text { Grades }\end{array}$ & Rehabilitation? \\
\hline $\begin{array}{l}\text { Check Dam } \\
\text { Construction }\end{array}$ & 13 & NA & $37 \%$ & Yes \\
\hline $\begin{array}{l}\text { LEB } \\
\text { Construction }\end{array}$ & $90-250$ LEBs/acre & 231 acres & $30-50 \%$ & Yes \\
\hline $\begin{array}{l}\text { Debris Rack } \\
\text { Construction }\end{array}$ & 3 & NA & $10-15 \%$ & No \\
\hline $\begin{array}{l}\text { Hand Mulching } \\
\text { and Crimping }\end{array}$ & 2.5 tons/acre & 75 acres & $20-40 \%$ & No \\
\hline Hand Seeding & $60-75$ lb/acre & 100 acres & $20-40 \%$ & No \\
\hline
\end{tabular}

Table 2. Summary of the application data for the erosion and sediment control treatments implemented at Lemon Dam (Wright Water Engineers, 2005).

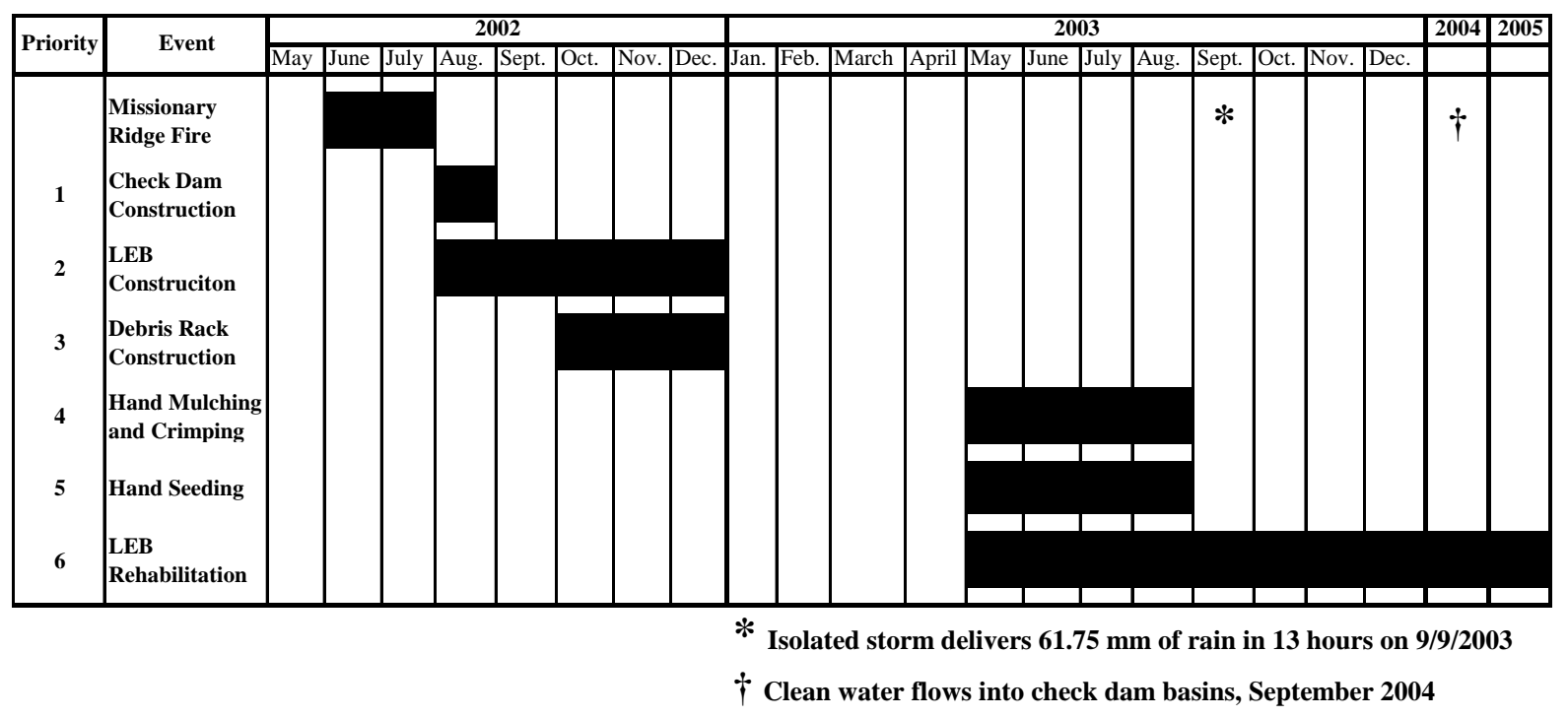

Table 3. Timeline of the erosion and sediment control program implemented at Lemon Dam, listed in order of priority (information from Florida Water Conservancy District, unpub. data). 


\section{Mulching}

At Lemon Dam over 190 tons (172 metric tons) of mulch were spread by hand and crimped (fig. 24) into over 250 acres (101 ha) of burned slopes (Wright Water Engineers, 2005). The hand-spread application was effective as an erosion-control treatment because it was spread thinly and evenly over the targeted slopes, a characteristic that provided good temporary ground cover. Crimping helps mulch to maintain contact with the soil and, if hydrophobic layers are detected in burned soils, crimping can break through the layer, allowing water to infiltrate rather than run off the surface. Uncrimped hand-spread mulch is vulnerable to clumping effects because wind can blow it around and deposit it in piles that can inhibit vegetation reestablishment.

Mulch can also be spread by helicopter, and the resulting application is often characterized by thick mounds and relatively uneven spreading patterns. The mounds are primarily due to insufficient breakup of airborne straw bales or to wind blowing the mulch into piles in the lee of obstacles such as trees. During heavy rains in these areas, the soil between mounds is highly vulnerable to erosion. Clumps will also suffocate the soil beneath, limiting vegetation regrowth even 2-3 yrs following a fire.

\section{Seeding}

The goal of seeding is to establish a protective vegetative cover until natural regrowth can occur, usually after one or two growing seasons. Typical application concentrations for larger areas are around $40 \mathrm{lbs} /$ acre $(45 \mathrm{~kg} / \mathrm{ha})$, although the erosioncontrol program at Lemon Dam used 60-75 lbs/acre (66-84 kg/ha). Observations of those slopes show that spreading this concentration among crimped mulch helped reestablish a vegetative cover during the first growing season (fig. 25). When seeds are applied in combination with straw mulch and(or) LEBs, plant reestablishment can occur more effectively after the first growing season, as mulch and LEBs may reduce hillslope erosion and hold seeds in place until germination.

\section{Check Dams}

Thirteen earthen check dams were constructed in the main channel of Knight Canyon above Lemon Dam. Figure 26, a photograph taken on September 9, 2003 (14 mo after the fire), shows a check dam filled with an ash/mud deposit during a heavy rain in the basin. In the background, another check dam can be seen in the series. The dams were monitored by the FWCD and cleaned out after such erosional events. Construction of check dams is expensive, difficult, and labor intensive, especially in steep upper reaches of a channel where access is limited. If debris-flow volume is too large for a check dam, or if the dams are improperly constructed, failure can occur and the debrisflow will incorporate the check-dam materials into the flow, increasing both its volume and erosive potential. This occurred in a basin burned by the Piru fire in southern California (Sue Cannon, oral commun., 2005). 


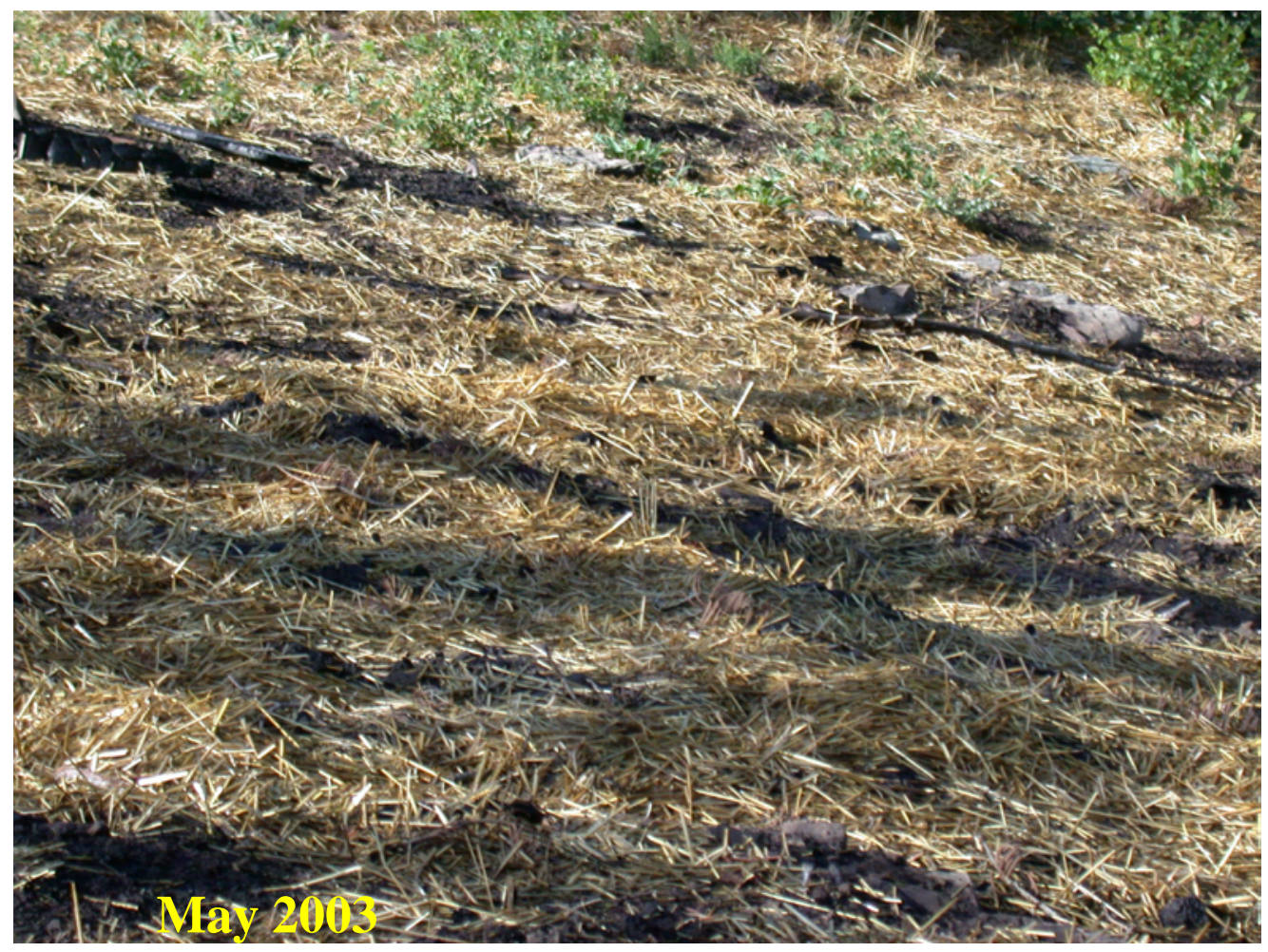

Figure 24. Condition of hand-spread and crimped mulch near Lemon Dam. Notice the vertical straws, products of crimping (photograph from Florida Water Conservancy District, unpub. data, 2003).

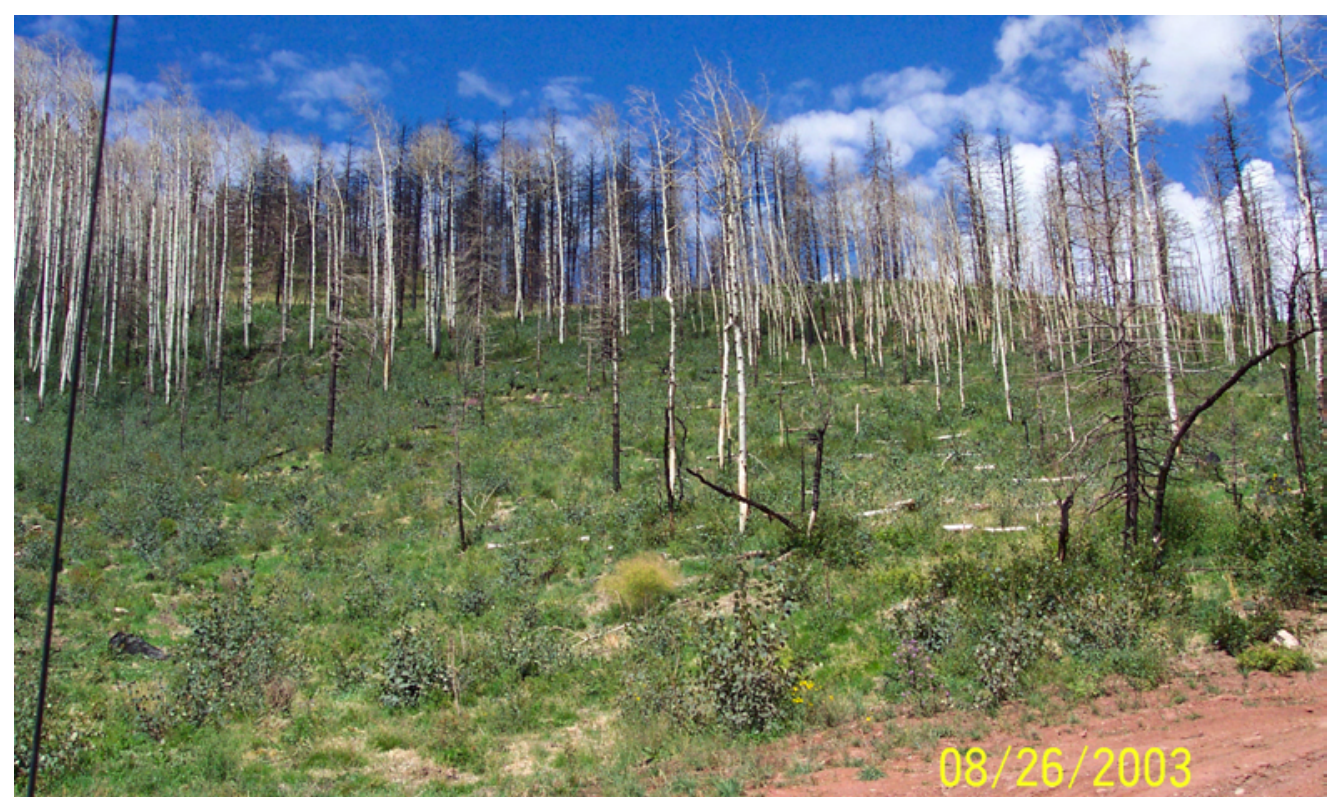

Figure 25. Photograph showing the amount of vegetative cover resulting from hand spread seeding near Lemon Dam in August 2003, approximately 13 mo after the fire. Some of the vegetation is natural growth (photograph from Florida Water Conservancy District, unpub. data, 2003). 


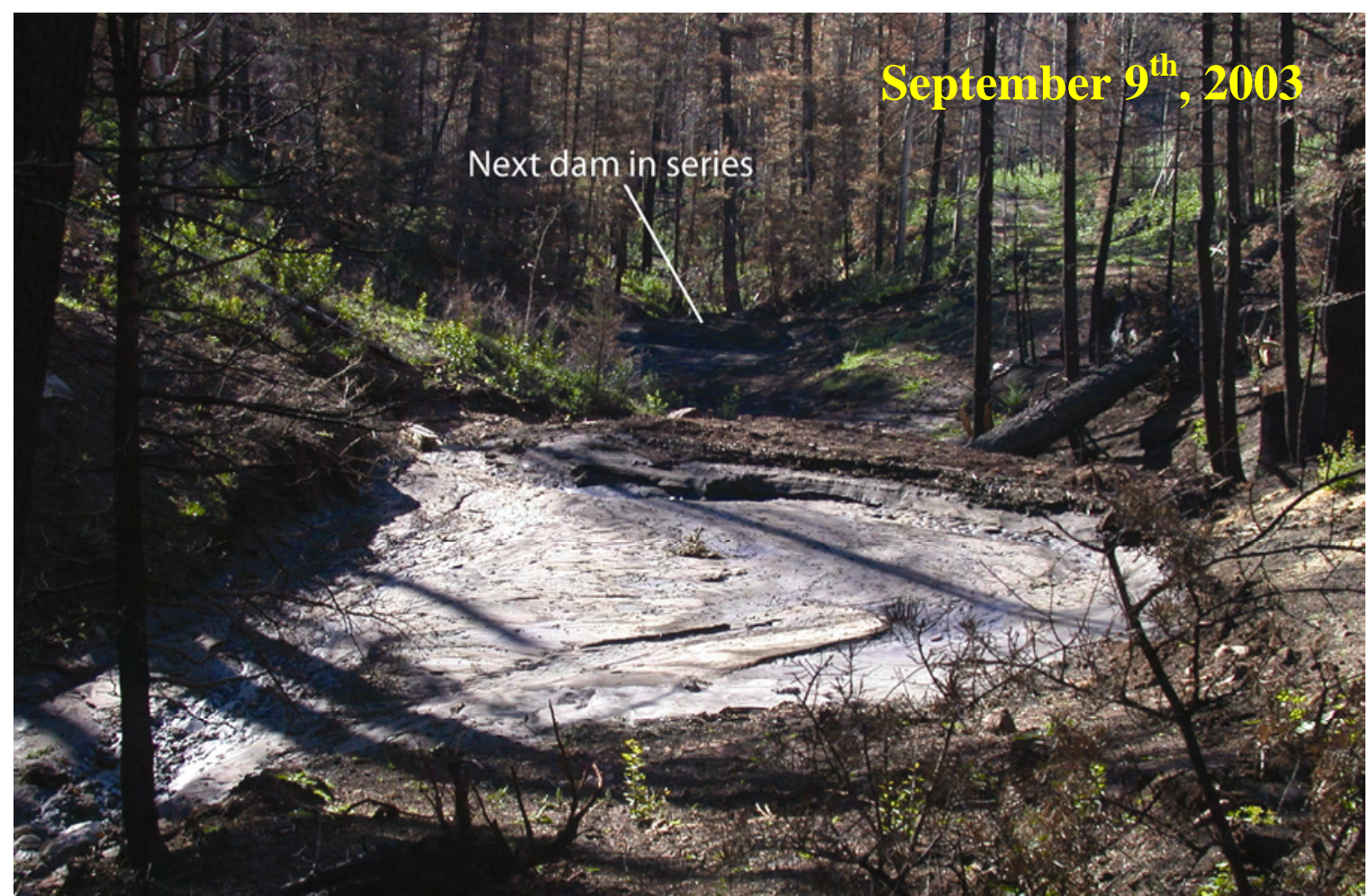

Figure 26. A check dam full of mud and debris in the upper reaches of Knight Canyon above Lemon Dam (photo from Florida Water Conservancy District, unpub. data, 2003).

\section{Debris Racks}

Five debris racks were constructed in the Lemon Dam sediment-control program between October and December 2002. Only one rack was located in a channel that produced a debris flow and it intercepted approx. $170 \mathrm{yd}^{3}\left(130 \mathrm{~m}^{3}\right)$ of a debris flow measured to be about $586 \mathrm{yd}^{3}\left(448 \mathrm{~m}^{3}\right)$ in total volume (fig. 27). The design of this debris rack prevented failure and allowed the fine material to continue down channel, where part of it was held back at a second debris rack. Only muddy water was passed on to the Florida River. The effectiveness of a debris rack in reducing debris-flow volume depends on its strength, design to pass fine-grained material, its position in the channel, and the size of the channel.

\section{The Florida River Landslide Area}

Landslide activity was observed by residents of the Florida River area during April and May 2005 on a hillslope burned by the 2002 Missionary Ridge fire. This hillslope is located above the Florida River and CR 243 about $1 \mathrm{~km}$ downstream from Lemon Dam (fig. 28). Landslide activity on the hillslope poses hazards to area residents and Lemon Dam, should activity be great enough to cause damming of the river. Members of the U.S. Geological Survey Landslide Hazards Project investigated the potential for additional landslide activity on the hillslope and associated hazards (Schulz and others, 2006). The investigation included engineering geologic mapping, subsurface exploration, and monitoring of surface displacement and shallow groundwater conditions. 


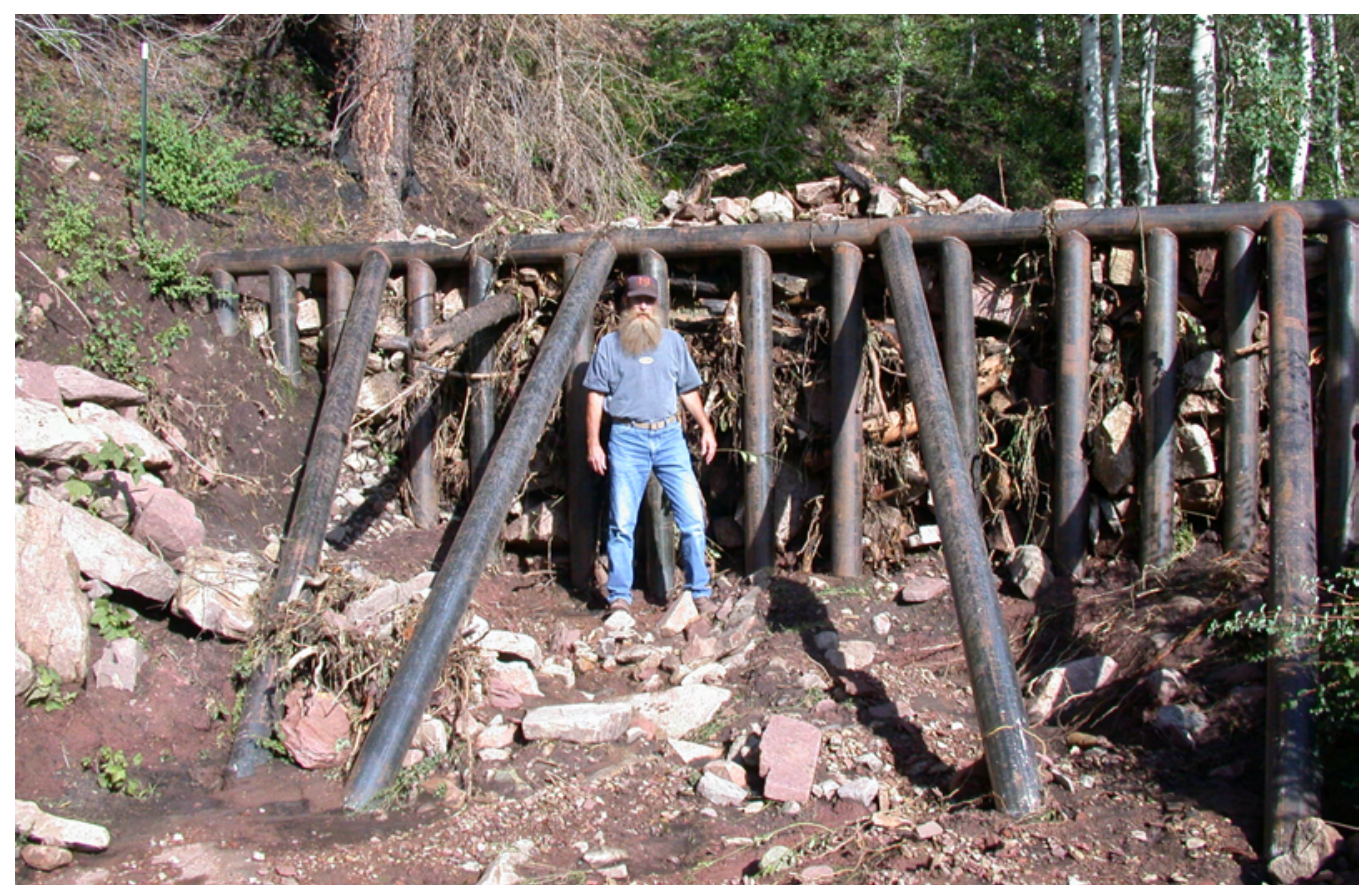

Figure 27. Debris rack holding back a slug of coarse debris and wood above a road and the spillway of Lemon Dam (photo from Florida Water Conservancy District, unpub. data, 2003).

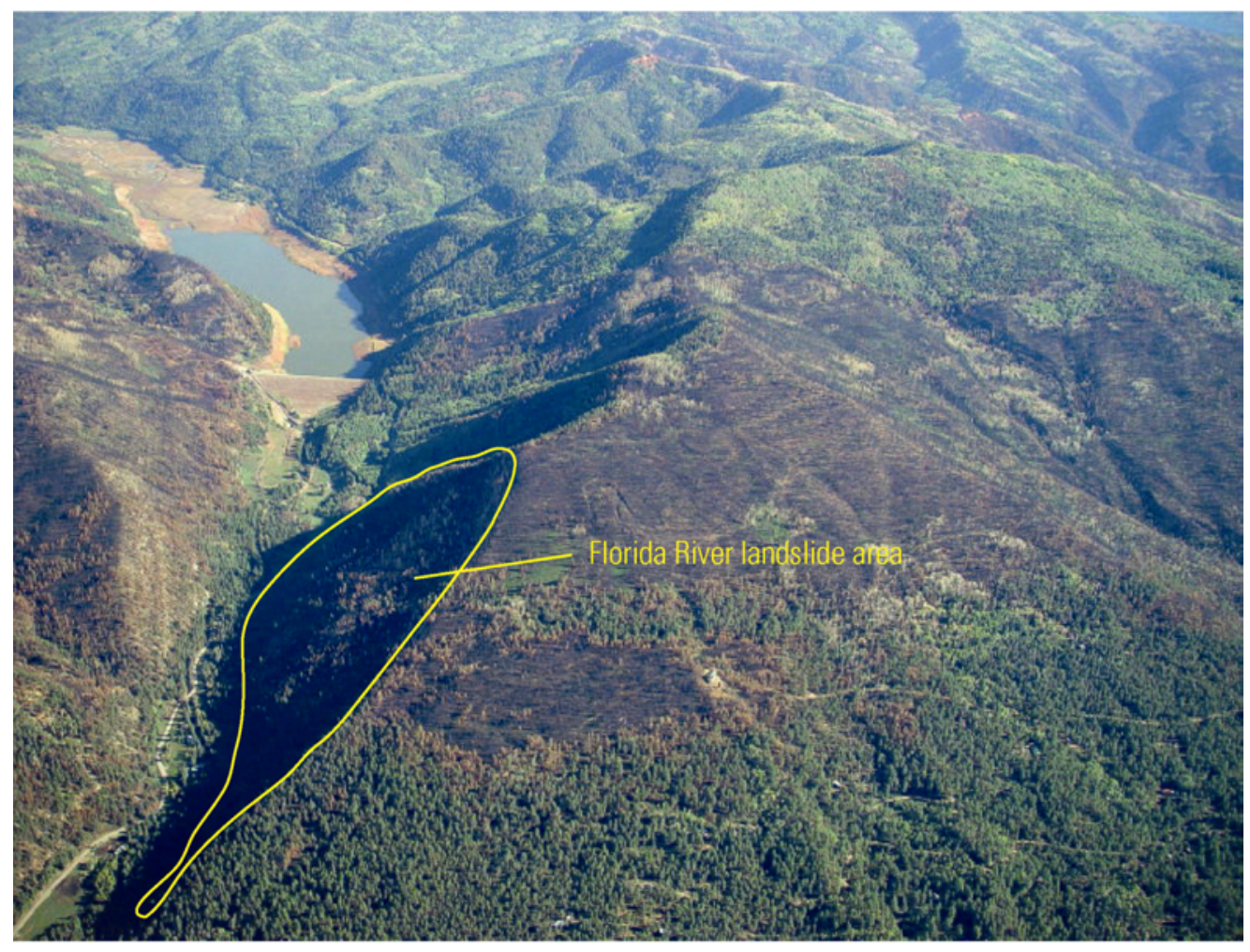

Figure 28. Aerial view of the Florida River landslide area within the Missionary Ridge burn area near Lemon Reservoir. Photograph courtesy of La Plata County. 
Landslide activity during the spring of 2005 included the formation of at least nine individual landslides that produced more than a dozen debris flows (fig. 29).

Landslide activity was concentrated upon a very large, apparently dormant landslide. Observed activity during 2005 was confined to a shallow (generally about $6 \mathrm{ft}$ (2 m) thick) mantle of colluvium. Landslides within the colluvium were translational debris slides (Cruden and Varnes, 1996) with volumes between 2,600 and 46,000 $\mathrm{yd}^{3}$ (2,000 and $35,000 \mathrm{~m}^{3}$ ). Debris flows were generally mobilized from dilated, mostly saturated, toe regions of the slides and ranged in volume from 200 to $2,000 \mathrm{yd}^{3}\left(150\right.$ to $1,500 \mathrm{~m}^{3}$ ) (fig. 30). Although generally quite small, debris flows traveled as far as about $980 \mathrm{ft}$ (300 m) downslope onto the Florida River floodplain. The landslides appeared to have been triggered by rapid melting of deep snow with high water content. Area residents had not observed landsliding on the hillslope previously (during about the past $30 \mathrm{yrs}$ ), although similar snowmelt events have occurred historically. It thus appears that landslide initiation was assisted by incineration of vegetation, which resulted in loss of root strength and evapotranspiration.

The dormant landslide upon which recent activity was concentrated occurs primarily in bedrock of the Morrison Formation. Dip-slope bedrock landslides in the Morrison and other units are common in the area (e.g., Blair, 1977; Carroll and others, 1997). However, the dormant landslide does not occur on a dip slope; rather bedrock orientation and landslide geometry indicate that the landslide truncates a 1,066-ft-thick (325 m) section of Jurassic and Cretaceous bedrock (fig. 29). The dormant landslide appears to be as much as about $230 \mathrm{ft}(70 \mathrm{~m})$ thick with an approximate volume of 25.7 million $\mathrm{yd}^{3}\left(19.7\right.$ million $\left.\mathrm{m}^{3}\right)$. When active, the landslide translated about $300 \mathrm{ft}(100 \mathrm{~m})$ downslope, likely damming the Florida River. Morphologic features suggest that the landslide may be quite old (thousands of years), but features were also observed that indicate that significant areas of the landslide have reactivated in the recent past. Samples obtained from a closed depression in the head of the landslide and at an apparent thrust of bedrock over soil have been submitted for radiometric dating. Abundant charcoal was identified at both locations, suggesting an influence of wildfire in initiating the landslide. Wildfire dating activities in the area (Frechette and others, 2003; Gonzales and others, 2003; Gonzales and others, 2005; Bigio and others, 2005) have identified many wildfires that occurred during the past several thousand years.

Future shallow landslide activity and associated debris flows will probably follow significant snowmelt events or periods of sustained, heavy rainfall. Characteristics of rainfall, snowmelt, and loss of vegetation due to wildfire that may result in future shallow landslide activity are being evaluated through limit-equilibrium and finite-element modeling. The potential for reactivation of the dormant landslide is largely unknown due to the lack of deep groundwater data. Renewed activity that occurs through the basal rupture zone of the dormant landslide would probably not result in rapid slope failure because that zone is most likely at relatively low residual strength, but the possibility remains for shallower bedrock landslides to form and mobilize rapidly. 


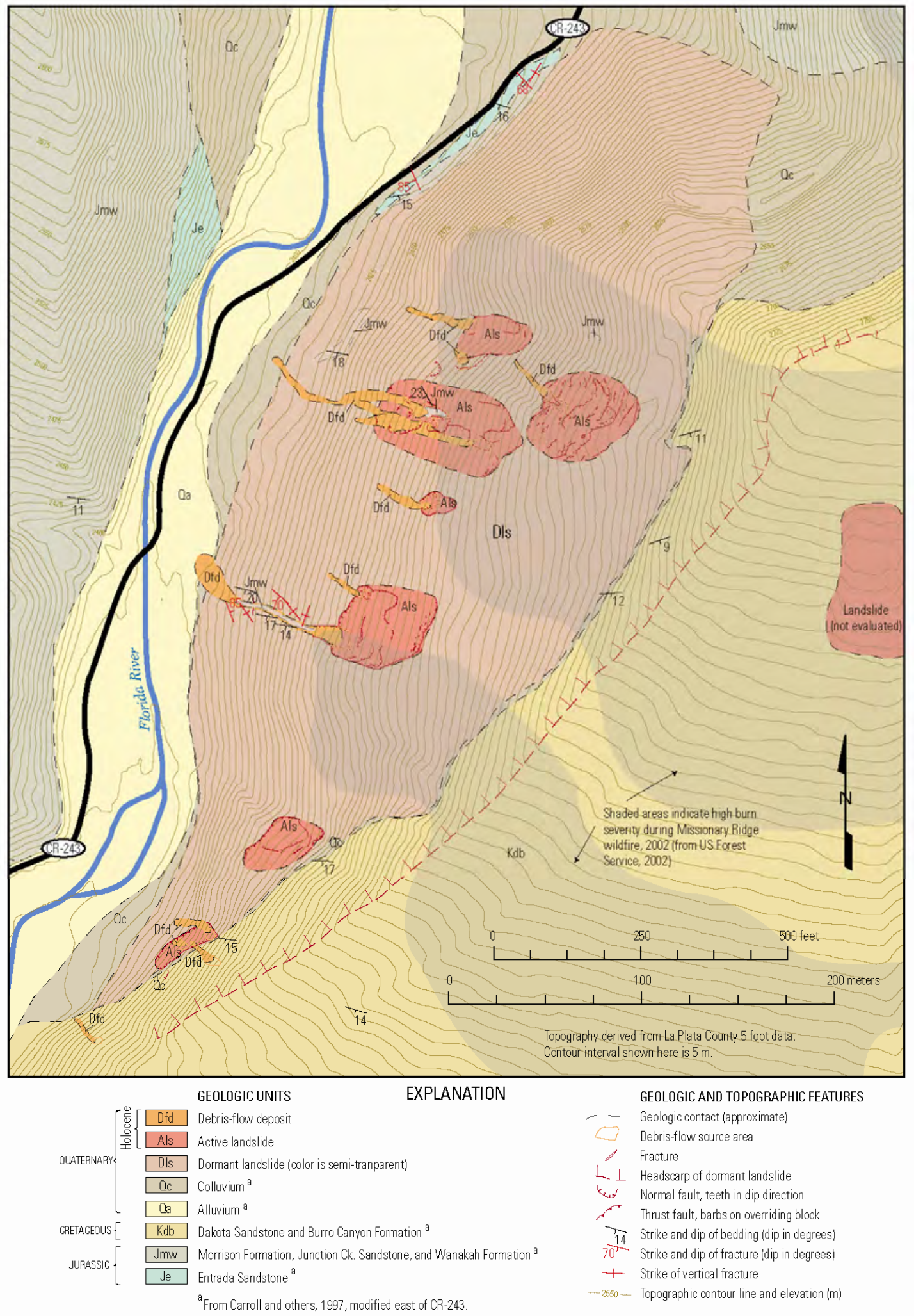

Figure 29. Geologic map of the Florida River landslide area. From Schulz and others (2006). 


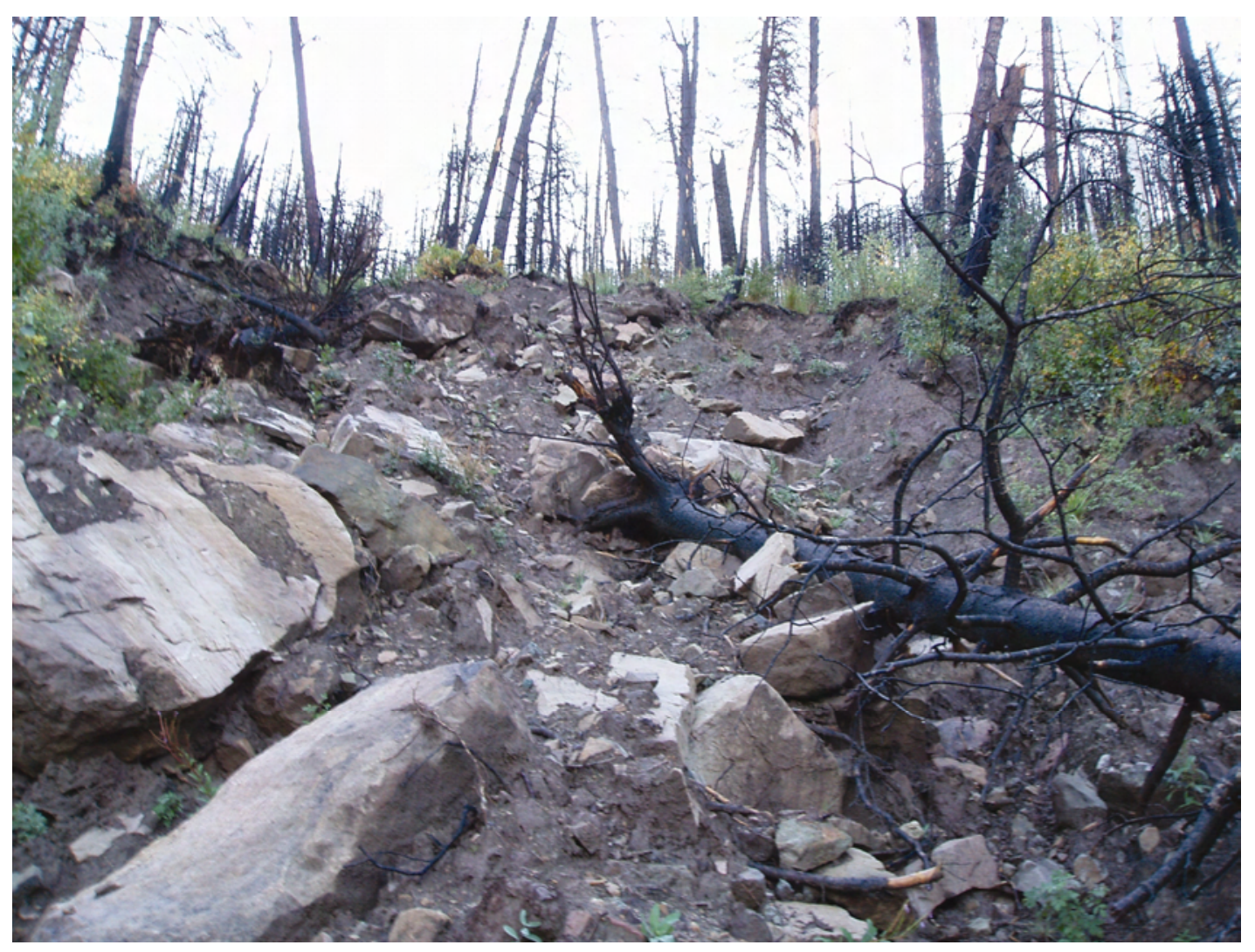

Figure 30. Debris flow source area formed in April 2005 in the Florida River landslide area.

Return to CR 243; drive south to the junction with CR 240. Turn east on CR 240 and proceed to the junction with CR 501. Turn north on CR 501 and proceed about $4 \mathrm{mi}$ to Stop 6 on the north side of Vallecito Reservoir.

\section{Stop 6. Fire and Debris Flow History in a Small Basin North of Vallecito Reservoir}

GPS location: N 37²6’ 14.7” W 107 33’ 35.4” Elevation: 7,847 ft (2,392 m) Stop Leader: Erica Bigio.

This stop focuses on a $1 \mathrm{~km}^{2}$ unnamed basin just north of Freeman Creek, burned almost entirely at moderate and high severity by the Missionary Ridge fire (fig. 31). The basin is underlain by sedimentary bedrock, and has hillslopes with gradients between 20 and 50 percent. The forest type is mixed-conifer with a species composition of Douglas fir, white fir, aspen, and ponderosa pine. Following the fire, several episodes of debris flow and flooding incised the channel and alluvial fan deposits (Cannon and others, 2003a), exposing a late Holocene record of fire-related sedimentation events (Gonzales and others, 2003). The exposed sediment record exhibited abundant charcoal within the deposits, providing an ideal opportunity to compare fire-related sedimentation events with tree-ring records of fire history. The goal of research in the basin has been to combine tree-ring and alluvial records at the scale of a single low-order basin. The 
annual resolution of the tree-ring records helps to interpret the timing of the younger alluvial deposits. In turn, the length of the alluvial records will extend the fire history for the study site.

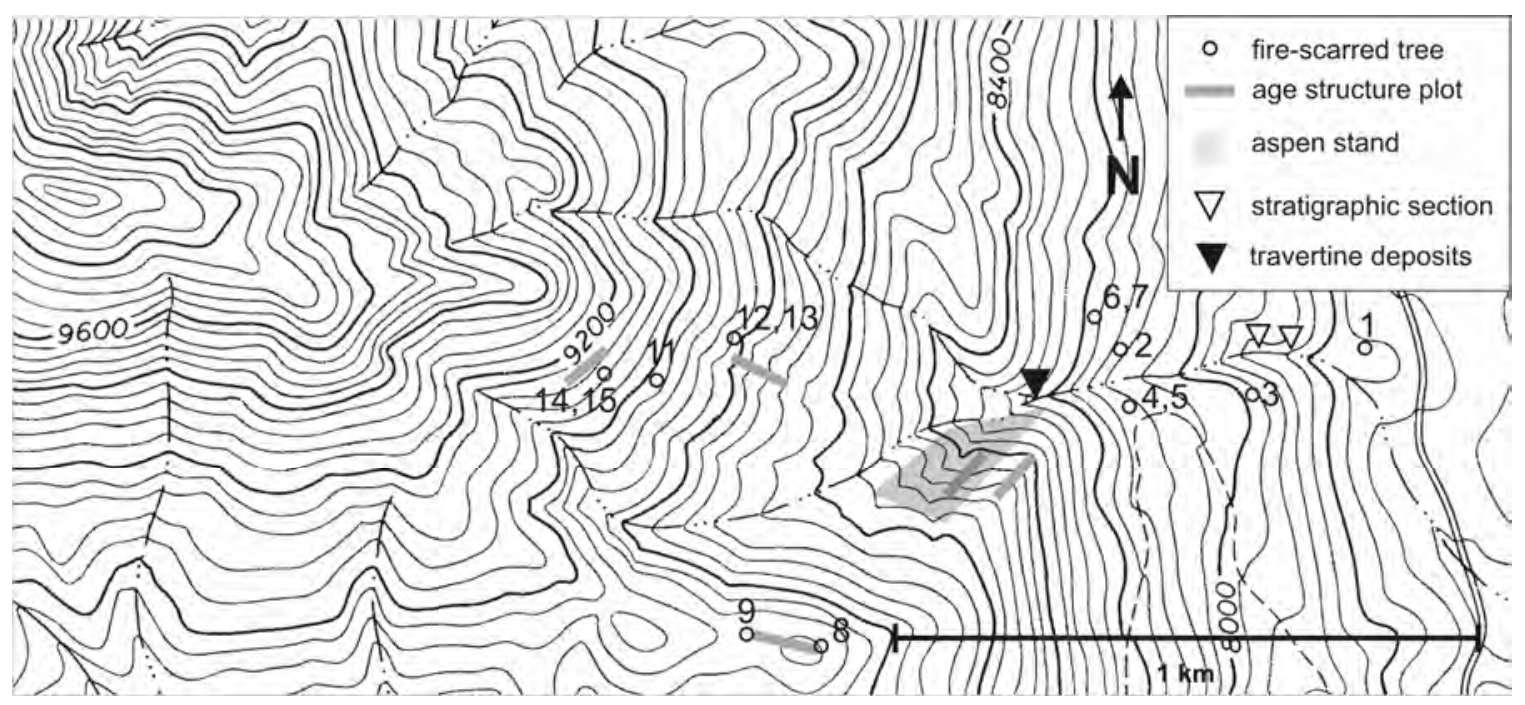

Figure 31. The Stop 6 study basin on the northwest side of Vallecito Reservoir. The basin was burned at approximately 80 percent moderate and high severity. Locations of tree-ring and alluvial sediment samples are noted. The fire-scar sample numbers correspond with the surface fire chronology in figure 34 .

The alluvial deposits were sampled within a 245-ft (75-m) reach of the exposed channel, feeding into the alluvial fan (fig. 32). Three stratigraphic sections were chosen for their height of natural exposure and the presence of charcoal concentrated in "burned" layers. The sediment characteristics of each stratigraphic unit were used to infer depositional processes, which were then used to infer the relative extent and severity of past fires. Debris-flow deposits with abundant angular charcoal indicate that a significant portion of the contributing basin burned at moderate and high severity (Meyer and others, 1995; Pierce and others, 2004). This inference comes from understanding the conditions that promote debris flow initiation in severely burned basins. For the Missionary Ridge fire, Cannon and others (2003a) found that all debris-flow-producing basins were burned with at least 50 percent moderate and high severities. Alternatively, fine-grained sheetflood and hyperconcentrated-flow deposits may represent a subset of low- and moderate-severity fires in the contributing basin (Pierce, 2004). The timing of past fire events was achieved by radiocarbon dating of charcoal pieces within each stratigraphic unit.

The goal of the tree-ring sampling was to identify both low- and high-severity fire behavior using a combination of tree-ring methods, including fire scars and agestructure data for aspen and conifers. Fire-scarred trees provided an annual record of low-severity surface fires, which were combined to identify the spatial and temporal patterns of surface fires. Aspen and conifer age-structure data show decadal patterns of 
forest regeneration, which may provide evidence of high-severity fire when associated with the surface-fire history. Ultimately, the component of high-severity fire, which occurs during widespread surface-fire years, may relate to young sediment deposits in the channel.
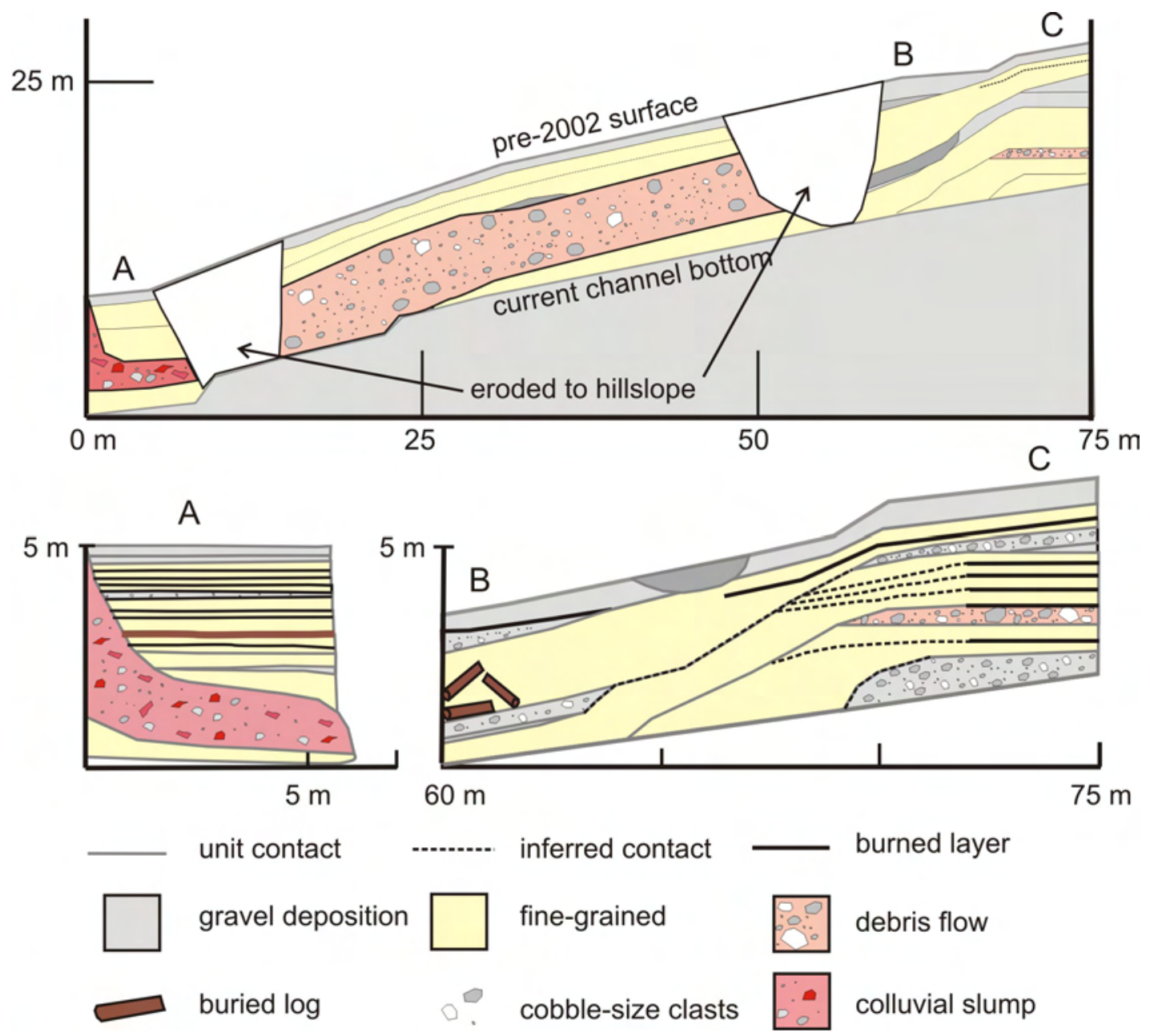

Figure 32. Exposed channel reach within the study basin northwest of Vallecito Reservoir, where three stratigraphic sections (A, B, C) were sampled. The deposit types included a fine-grained, gravel-rich debris flow and a colluvial slump. Several buried logs were exposed in stratigraphic section B.

\section{Sediment Results}

The majority of the alluvial deposits were fine-grained and well-sorted, and exhibited a range of silt- to gravel-sized sediment. Gravel-sized clasts were usually supported by a silt-rich matrix with little evidence of clast orientation. Within thicker (3 $\mathrm{ft}, 1 \mathrm{~m}$ ) fine-grained deposits, the gravel-sized clasts were concentrated in 0.3 -ft-thick $(10-\mathrm{cm})$ lenses, indicating weak stratification of the deposits. The key feature of the fine- 
grained deposits was the light yellow color, which reflected a source of travertine within the channel in the center of the basin. The travertine source location suggests that the fine-grained deposits represented reworked channel sediments, with little entrainment of hillslope material.

Some fine-grained deposits had a gray matrix supporting scattered gravel- and cobble-sized clasts. The darker color of the matrix suggested a component of hillslope sediment mixed with the channel material. The matrix of these deposits did not exhibit stratification, yet the range of clast sizes was not sufficient to interpret these deposits as debris-flow deposits. They were possibly deposited by hyperconcentrated flow conditions.

Two other deposits more clearly indicated debris-flow deposition. The first was a broad deposit exposed for several meters along the length of the exposure between stratigraphic sections $\mathrm{A}$ and $\mathrm{B}$, and the second was a thin, localized deposit exposed at stratigraphic section C (fig. 32). The darker matrix of these deposits indicated a hillslope sediment source. The matrix supported a poorly-sorted mix of clasts, composed of both local and regional lithologies, relating to reworked glacial-till deposits on the hillslopes.

Some of the stratigraphic units were also bound by charcoal-rich "burned" layers. From visual inspection, these appeared to have been deposited by hydrological processes, rather than being in-situ burned soil horizons. They sometimes defined weak stratification, and were primarily composed of silt- and sand-sized charcoal fragments. Occasionally the burned layers were very prominent and could be traced for several meters along the length of the exposure. One such layer was a $0.3-\mathrm{ft}$-thick $(10-\mathrm{cm})$ deposit near the top of stratigraphic section B (fig. 32), which had burned wood chunks (0.6-1.0 ft, or 20-30 cm, in length) and smaller angular charcoal pieces supported by a dark gray, silty matrix.

All deposits contain abundant charcoal and can therefore be linked to fire activity in the contributing basin. The two debris-flow deposits have very similar radiocarbon ages and likely represent the same disturbance event. The event was likely a highseverity fire that occurred between 2,800 and 2,400 cal yr B.P. (2,500 ${ }^{14} \mathrm{C}$ yr B.P.). This was followed by continuous fine-grained deposition, which has been aggrading in the channel over the past 2,000 years. Locally within each stratigraphic section, the deposition has been episodic, with periods of rapid sediment deposition followed by depositional hiatuses (fig. 33). The youngest alluvial deposits occurred within the past 500 calendar years and have broad age ranges due to the conversion between radiocarbon years and calendar years. The thick burned layer described above has an age range of A.D. $1600-1950$.

\section{Tree-Ring results}

The evidence from fire-scarred trees shows that low-severity surface fire has been frequent over the past 400 yrs, with a clear cessation following the last widespread surface fire in 1879. The surface-fire chronology (fig. 34) shows that fires were more frequent and patchy during the late $17^{\text {th }}$ and $18^{\text {th }}$ centuries, but became more synchronous and widespread during the $19^{\text {th }}$ century. 


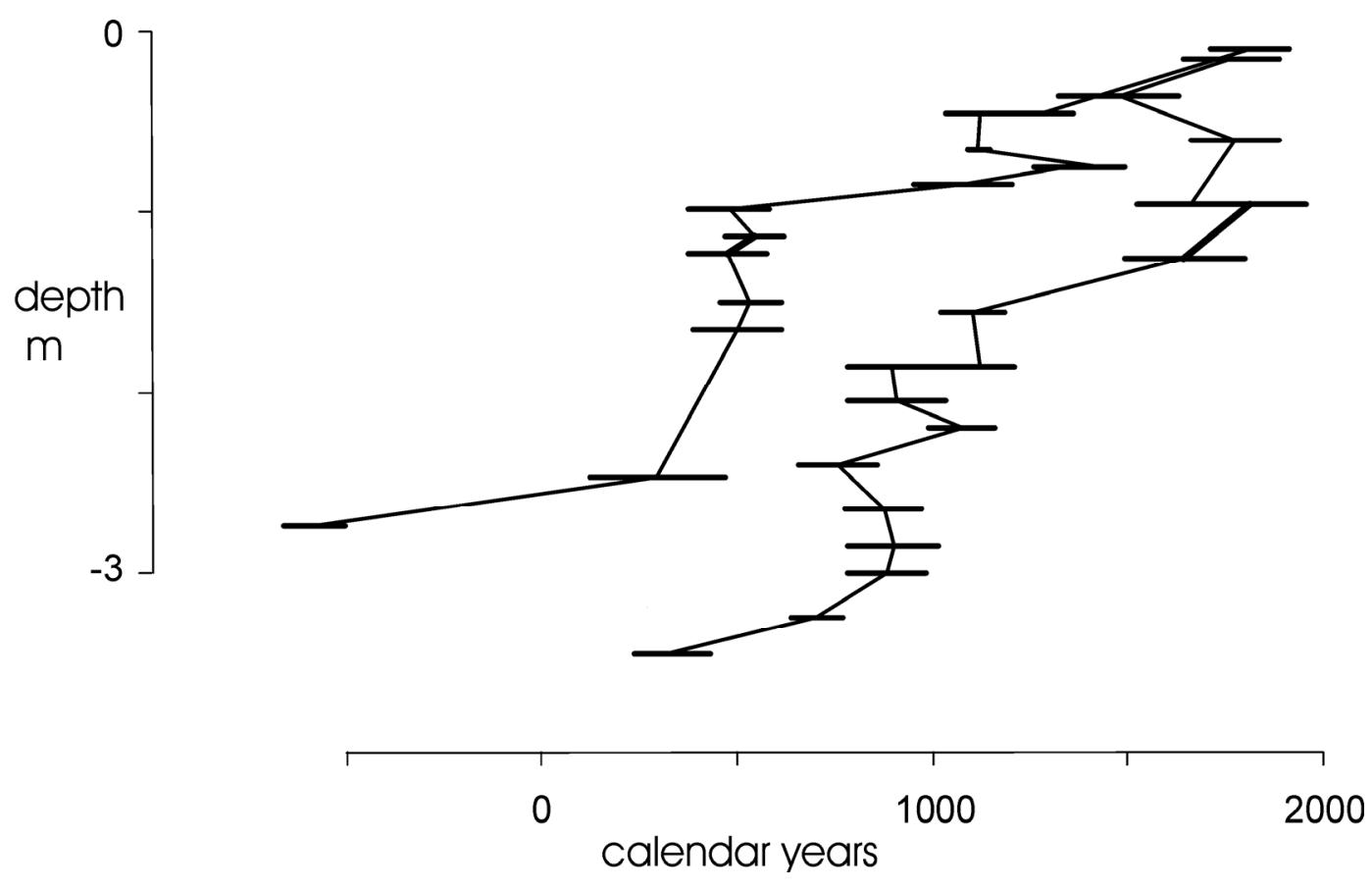

Figure 33. Chronology of fine-grained deposition northwest of Vallecito Reservoir, recorded in two stratigraphic sections. The horizontal bars represent the 2-sigma calendar age ranges of individual charcoal pieces from each sediment layer. The depth of each bar is the median depth of the layer where the sediment was sampled.

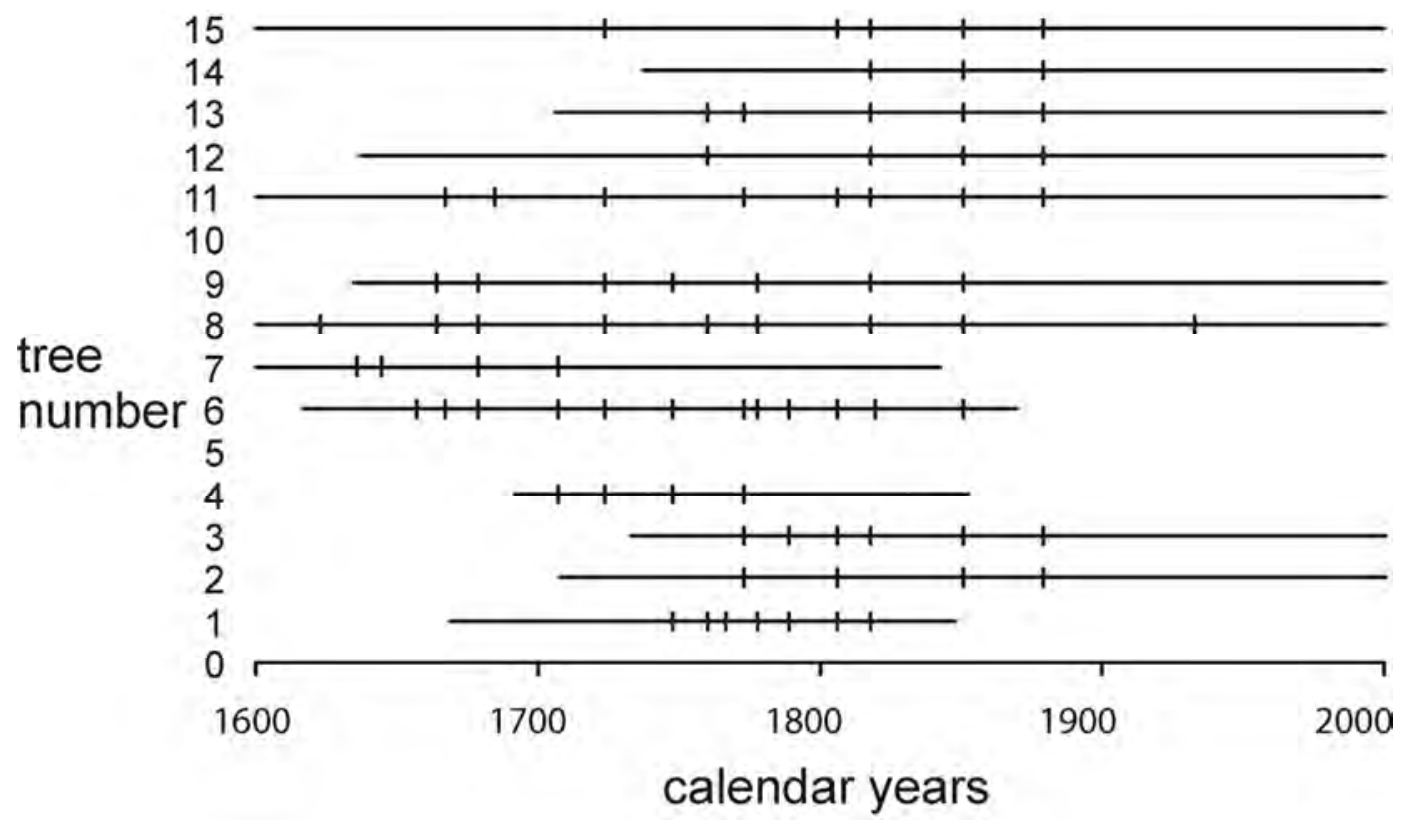

Figure 34. Surface fire chronology northwest of Vallecito Reservoir. The surface fire chronology represents each fire-scarred tree with a horizontal line, organized in order of elevation in the basin. Each tree has multiple fire scars, which are represented by the tick marks along the line. 
There is some evidence of small patches of high-severity fire occurring during two of the widespread surface fire years in the $19^{\text {th }}$ century. The age-structure data collected from conifer and aspen trees suggest that there were small patches of highseverity fire burning in both the years 1851 and 1879. The aspen stand located on the north-facing slope has a germination age of 1879 and is the largest area (25-acre, or 10ha, patch) of possible high-severity fire. The evidence is not conclusive, but provides the best link between the tree-ring and alluvial records.

\section{Discussion}

The fine-grained deposition, although episodic, represents generally stable conditions in the basin. In this type of steep mountainous terrain, step-pools created by log jams and boulders are the main mechanism for trapping and storing fine-grained sediment (Wohl, 2000). These step-pools remain stable during low-flow events (1- to 5-yr recurrence interval), while infrequent high-flow events (30- to 50-yr recurrence interval) locally scour and fill pools (Faustini and Jones, 2003).

The fine-grained deposition indicates sediment transport in response to infrequent high-flow events, possibly generated by high recurrence-interval storms. Although there was abundant charcoal within the fine-grained deposits, the transport and deposition of channel sediment was probably unrelated to fire-related disturbance in the basin. The abundance of charcoal represents a low-severity fire regime, where frequent surface fires produced charcoal on the hillslopes, which was transported to the channel by surface runoff. Separately, high-flow events transported and deposited charcoal and sediment behind obstructions in the channel. In the case of stratigraphic section A (fig. 32), it seems as if a colluvial slump (possibly following the debris-flow event at or near 2,600 cal yr B.P.) provided the obstruction for sediment accumulation in this portion of the channel.

Fine-grained deposits with a darker matrix supporting gravel- to cobble-sized clasts probably represent specific fire-related disturbance events. Over the length of the tree-ring record, patches of high-severity fire occurred during some of the widespread surface-fire years. These patches could generate sufficient runoff to mobilize and transport channel sediment, while also incorporating hillslope sediment from the disturbed area of the basin. One possible example is the thick burned layer exposed at the top of stratigraphic section B (fig. 32). This deposit overlies a fine-grained deposit with a darker matrix, supporting cobbles up to $0.4 \mathrm{ft}(15 \mathrm{~cm})$ in diameter. The two deposits are probably related to the same disturbance event, occurring between A.D. 1600 and 1950. These deposits probably relate to the patch of high-severity fire, indicated by the aspen stand, which occurred in 1879. This was also a year when a large high-severity fire burned in the upper elevation spruce-fir forests near Silverton, Colorado.

In the case of the debris-flow deposit, the link to more-extensive high-severity fire is clear. Debris-flow initiation requires significant runoff to entrain hillslope and channel sediment. The dark matrix suggests that hillslope sediments were entrained in the deposit, while the abundant charcoal links the deposit to a fire-related disturbance. The timing of this event (around 2,600 cal yr B.P.) is likely related to the neoglacial period of cooler and wetter conditions during the late Holocene. A lake sediment record of fire history shows that this period had less frequent, but more intense, fires in the upper elevation spruce-fir forests near Silverton, Colorado (Toney and Anderson, 2006). 
The Missionary Ridge fire appears to be unusual in its high-severity patch size when compared with fire events interpreted from tree-ring records and fine-grained deposition over the past 2,000 yrs. This type of fire behavior has likely not occurred in this study basin since the last debris-flow event at or near 2,600 cal yr B.P. This previous debris-flow event may relate to longer-term changes in forest structure relating to climatic conditions at this time. The high-severity fire behavior of the recent event, however, seems predominantly influenced by human-induced changes in forest structure as a result of fire exclusion in this ecosystem.

Return to Durango via CR501 and CR240. End of Field Trip.

\section{Acknowledgements}

Several of the contributors to this guidebook participated in a May 2003 Geological Society of America (GSA) field trip entitled "Erosion and sedimentation following the 2002 Missionary Ridge fire". The GSA trip was organized and led by Andy Gleason of the Colorado Geological Survey. This Shlemon Conference field trip follows a similar route and has greatly benefited from Andy's observations, insights, and contacts. Additionally, we thank Bob Schuster, Bill Ellis, and Melanie Parker for providing constructive reviews of this guidebook.

\section{References Cited}

Applegate, P.J., 2005, Synchroneity of last glaciation in the western United States, with some observations on the glacial history of the San Juan Mountains, Colorado: West Lafayette, Purdue University, M.S. thesis, 178 p.

Benson, L., Madole, R., Landis, G., and Gosse, J., 2005, New data for late Pleistocene Pinedale alpine glaciation from Southwestern Colorado: Quaternary Science Reviews, v. 24, p. 49-65.

Bigio, E.R., Swetnam, T., and Baisan, C., 2005, The integration of tree-ring and alluvial fan records of fire history at the Missionary Ridge fire near Durango, Colorado [abs.]: Geological Society of America Abstracts with Programs, v. 37, no. 7, p. 111.

Blair, R.W., Jr., 1977, Surficial geologic map and geologic hazards map of Rules Hill quadrangle; map prepared by Four Corners Environmental Research Institute for La Plata County Planning Department, scale 1:24,000.

Blair, R., ed., 1996, The western San Juan Mountains, their geology, ecology, and human history: University Press of Colorado, Niwot, Colo., 406 p.

Burn Area Emergency Rehabilitation (BAER) Team, 2002, Missionary Ridge and Valley fires burned area emergency stabilization and rehabilitation plan: U.S. Forest Service, Bureau of Land Management, U.S. Geological Survey, 251 p.

http://www.fs.fed.us/r2/sanjuan/fire/missridge/baerreport.htm. 
Cannon, S.H., 2000, Debris-flow response of southern California watersheds burned by wildfire, in Wieczorek, G.F., and Naeser, N.D., eds, Second International Conference on Debris-flow Hazards Mitigation, Taipei, Taiwan, 16-18 August, 2000, Proceedings: Rotterdam, A.A. Balkema, p. 45-52.

Cannon, S.H., 2001, Debris-flow generation for recently burned watersheds: Environmental \& Engineering Geoscience, v. 7, no. 4, p. 321-341.

Cannon, S.H., and Gartner, J.E., 2005, Wildfire-related debris flow from a hazards perspective: Chapter 15 in Hungr, O., and Jacob, M., eds., Debris-flow hazards and related phenomena: New York, Springer-Praxis, p. 321-344.

Cannon, S.H., Gartner, J.E., Holland-Sears, A., Thurston, B.M., and Gleason, J.A., 2003a, Debris-flow response of basins burned by the 2002 Coal Seam and Missionary Ridge Fires, Colorado, in Boyer, D.D., Santi, P.M., Rogers, P., Engineering geology in Colorado, contributions, trends, and case histories: Association of Environmental \& Engineering Geologists Special Publication No. 15, 30 p.

Cannon, S.H., Gartner, J.E., Rupert, M.G., Michael, J.A., Djokic, D., Sreedhar, S., 2003c, Emergency assessment of debris-flow hazards from basins burned by the Grand Prix and Old Fires of 2003, southern California: U.S. Geological Survey Open-File Report 03-475, 1 sheet containing maps and text.

Cannon, S.H., Michael, J.A., Gartner, J.E., and Gleason, J.A., 2003b, Assessment of potential debris-flow peak discharges from basins burned by the 2002 Missionary Ridge Fire, Colorado: U.S. Geological Survey Open File Report 03-332, 1 sheet containing maps and text.

Cannon, S.H., Powers, P.S., Savage, W.Z., 1998, Fire-related hyperconcentrated and debris flows on Storm King Mountain, Glenwood Springs, Colorado, USA:

Environmental Geology, v. 35, no. 2-3, p. 210-218.

Carroll, C.J., Gillam, M.L., Ruf, J.C., Loseke, T.D., and Kirkham, R.M., 1999, Geologic map of the Durango East quadrangle, La Plata County, Colorado-description of map units, fracture data and analysis, economic geology and references: Colorado Geological Survey Open-File Report 99-6, 45 p., one map scale 1:24,000.

Carroll, C.J., Kirkham, R.M., and Wilson, S.C., 1998, Geologic map of the Ludwig Mountain quadrangle, La Plata County, Colorado-description of map units, economic geology, fracture data and references: Colorado Geological Survey Open-File Report 982, 23 p., one map scale 1:24,000.

Carroll, C.J., Kirkham, R.M., and Wracher, A., 1997, Geologic map of the Rules Hill quadrangle, La Plata County, Colorado-description of map units, economic geology and 
references: Colorado Geological Survey Open-File Report 97-1, 12 p., one map scale $1: 24,000$.

Cleveland, G.B., 1973, Fire and rain = mudflows, Big Sur, 1972: California Geology, v. 26, p. 127-135.

Coe, J.A., and Burke, M., 2003, Historic landslides in the San Juan Mountains, southwestern Colorado [abs.]: Geological Society of America Abstracts with Programs, v. 35 , no. 5 , p. 8 .

Colorado Department of Local Affairs, 2002, Overview of 2002 Fires: Denver, Colo., Colorado Department of Local Affairs, http://www.dola.state.co.us/oem/Publicinformation/firebans/CO_Fires1.pdf, May, 2006.

Colton, R.B., Holligan, J.A., and Anderson, L.W., 1975, Preliminary map of landslide deposits, Durango 1 deg x 2 deg quadrangle, Colorado: U.S. Geological Survey MF-703, scale 1:250,000.

Cruden, D.M., and Varnes, D.J., 1996, Landslide types and processes, in Turner, A.K., and Schuster, R.L., eds., Landslides, investigation and mitigation: Transportation Research Board Special Report 247, Washington, D.C., National Research Council, p. $36-75$.

DeGraff, J.V., 1997, Geologic investigation of the Pilot Ridge debris flow, Groveland Ranger District, Stanislaus National Forest: U.S. Department of Agriculture Forest Service Report, 20 p.

deWolfe, V.G, Santi, P.M., Ey, J., and Gartner, J.E., 2005, Arrest of a debris flow at Lemon Dam, La Plata County, Colorado using erosion control mitigation [abs.]: Geological Society of America Abstracts with Programs, v. 37, no. 7, p. 36.

Doehring, D.O., 1968, The effect of fire on geomorphic processes in the San Gabriel Mountains, California: Contributions to Geology, v. 7, no. 1, p. 43-65.

Doerr, S.H., Shakesby, R.A., and Walsh, R.P.D., 2000, Soil water repellency—its causes, characteristics and hydro-geomorphological significance: Earth-Science Reviews, v. 51, pp. 33-65.

Eaton, E.C., 1935, Flood and erosion control problems and their solution: American Society of Civil Engineers Transactions, paper no. 1950, v. 101, p. 1,302-1,362.

Elliott, J.G., Smith, M.E., Friedel, M.J., Stevens, M.R., Bossong, C.R., Litke, D.W., Parker, R.S., Costello, C., Wagner, J., Char, S.J., Bauer, M.A., and Wilds, S.R., 2004, Analysis and mapping of post-fire hydrologic hazards for the 2002 Hayman, Coal Seam, and Missionary Ridge wildfires, Colorado: U.S. Geological Survey Scientific Investigations Report 2004-5300, 104 p. 
Faustini, J.M. and Jones, J.A., 2003, Influence of large woody debris on channel morphology and dynamics in steep, boulder-rich mountain streams, western Cascades, Oregon: Geomorphology, v. 51, no. 1-3, p. 187-205.

Frechette, J.D., Gonzales, D.A., Kenny, R., and Thompson, J.R., 2003, Evidence for a connection between wildfires, erosion, and landscape development over the past 3,600 years in southwestern Colorado [abs.]: Geological Society of America Abstracts with Programs, v. 35, no. 6, p. 36.

Gartner, J.D., 2003, Erosion after wildfire: the effectiveness of log erosion barriers: Boulder, University of Colorado, M.S. thesis, 70 p.

Gartner, J.E., 2005, Relations between wildfire related debris-flow volumes and basin morphology, burn severity, material properties and triggering storm rainfall: Boulder, University of Colorado, M.A. thesis, 87 p.

Gillam, M., 1998, Late Cenozoic geology and soils of the lower Animas River valley, Colorado and New Mexico: Boulder, University of Colorado, Ph.D. thesis, 477 p.

Gonzales, D.A., Frechette, J.D., Starr, D.W., III, Osmerra, T., Morse, N., and Graham, K., 2005, Geologic map of the Vallecito Reservoir quadrangle, La Plata County, CO: Colorado Geological Survey Open File Report 04-09, scale 1:24,000.

Gonzales, D.A., Matthews, V., III, and Frechette, J.D., 2003, Insight into a record of fire and related debris flows in southwestern Colorado [abs.]: using geologic mapping and field studies to understand the past and to predict future events: Geological Society of America Abstracts with Programs, v. 35, no. 6, p. 69.

Gonzales, D.A., Stahr, D.W., III, Kirkham, R.M., 2002, Geologic map of the Hermosa quadrangle, La Plata County, Colorado: Colorado Geological Survey Open-File Report 02-1, scale 1:24,000.

Greenhill, Jim, 2002, Fire in the sky, Colorado’s Missionary Ridge fire: Durango, Colorado, Durango Herald, Small Press, 117 p.

Kostka, Jennifer, 2002, Vallecito area sees ash flows, flooding: Durango Herald [Colorado], July 23, 2002.

Kostka, Jennifer, Crane, Daniel, and Greenhill, Jim, 2002, Mud shuts off roads, hits homes, Durango Herald [Colorado], July 24, 2002.

Krochenski, A.W. and Kenny, R., 2003, Engineering properties and site characterization of the Helens's store landslide, Durango, Colorado [abs.]: Geological Society of America Abstracts with Programs, v. 35, no. 5, p. 36. 
La Plata County, 2006, Office of Emergency Management website, Durango, Colorado, http://www.laplataoem.org/, April, 2006.

MacLachlan, M.E., 1981, Stratigraphic correlation chart for western Colorado and northwestern New Mexico, in Epis, R.C., and Callender, J.F., eds., Western Slope Colorado, New Mexico Geological Society Thirty-Second Field Conference, Proceedings, p. 75-79.

Martin, D.A., and Moody, J.A., 2001, Comparison of soil infiltration rates in burned and unburned mountainous watersheds: Hydrological Processes, v. 15, p. 2,893-2,903.

Meyer, G.A., 2002, Fire in western conifer forests - geomorphic and ecologic processes and climatic drivers [abs.]: Geological Society of America Abstracts with Programs, v. 34, no.6, p. 46.

Meyer, G.A., Pierce, J.L., Wood, S.H., and Jull, A.J.T., 2001, Fire, storms, and erosional events in the Idaho Batholith: Hydrologic Processess, v. 15, p. 3,025-3,038.

Meyer, G.A., and Wells, S.G., 1997, Fire-related sedimentation events on alluvial fans, Yellowstone National Park, U.S.A.: Journal of Sedimentary Research, v. 67, no. 5, p. 776-791.

Meyer, G.A., Wells, S.G., Jull, A.J.T., 1995, Fire and alluvial chronology in Yellowstone National Park-Climatic and intrinsic controls on Holocene geomorphic processes: Geological Society of America Bulletin v. 107, no. 10, p. 1,211-1,230.

Moody, J.A., and Martin, D.A., 2001, Hydrologic and sedimentologic response of two burned watersheds in Colorado: U.S. Geological Survey Water Resources Investigative Report 01-4122, 138 p.

Morton, D.M., 1989, Distribution and frequency of storm-generated soil slips on burned and unburned slopes, San Timoteo Badlands, Southern California, in Sadler, P.M., and Morton, D.M., eds., Landslides in a semi-arid environment with emphasis on the inland valleys of Southern California: Publications of the Inland Geological Society, v. 2, p. 279-284.

Parrett, C., 1987, Fire-related debris flows in the Beaver Creek drainage, Lewis and Clark County, Montana: U.S. Geological Survey Water-Supply Paper 2330, p. 57-67.

Pielke, R.A., Doesken, N., Bliss, O., Green, T., Chaffin, C., Salas, J.D., Woodhouse, C.A., Lukas, J.J., and Wolder, K., 2005, Drought 2002 in Colorado: An unprecedented drought or a routine drought?: Pure and Applied Geophysics, v. 162, p. 1,455-1,479.

Pierce, J.L., 2004, Holocene fire regimes and geomorphic response in conifer forests of central Idaho: evidence of millennial scale climate change: Albuquerque, N. Mex., University of New Mexico, Department of Earth and Planetary Sciences: 235 p. 
Pierce, J.L., Meyer, G.A., Jull, A.J.T., 2004, Fire-induced erosion and millennial scale climate change in northern ponderosa pine forests: Nature, v. 432, p. 87-90.

Pierce, K.L., 2003, Pleistocene glaciations in the Rocky Mountains, in Gillespie, A., Porter, S., and Atwater, B., eds., The Quaternary Period in the United States:

Amsterdam, Elsevier, p. 63-76.

Pierson, T.C., 2005, Distinguishing between debris flows and floods from field evidence in small watersheds: U.S. Geological Survey Fact Sheet 2004-3142, 4 p.

Robichaud, P.R., 2005, Measurement of post-fire hilllslope erosion to evaluate and model rehabilitation treatment effectiveness and recovery: International Journal of Wildland Fire, v. 14, p. 475-485.

Schulz, W.H., Coe, J.A., Ellis, W.L., and Kibler, J.D., 2006, Preliminary assessment of landslides along the Florida River downstream from Lemon Reservoir, La Plata County, Colorado: U.S. Geological Survey Open File Report 2006-1343, 29 p., 1 plate.

Scott, K.M., 1971, Origin and sedimentology of 1969 debris flows near Glendora, California: U.S. Geological Survey Professional Paper 750-C, p. C242-C247.

Toney, J., and Anderson, R.S., 2006, A postglacial paleoecological record from the San Juan Mountains of Colorado: fire, climate and vegetation history: The Holocene, v.16, no. 4, p. 505-517.

Wells, H.G., 1987, The effects of fire on the generation of debris flows in southern California, in Costa, J.E., and Wieczorek, G.F., eds., Debris flows/avalanches_process, recognition, and mitigation: Geological Society of America Reviews in Engineering Geology, v. 7, p. 105-114.

Wohl, E.E., 2000, Mountain rivers: Washington, D.C., American Geophysical Press, 320 p.

Wohl, E.E., and Pearthree, P.P., 1991, Debris flows as geomorphic agents in the Huachuca Mountains of southeastern Arizona: Geomorphology, v. 4, p. 273-292.

Wohlgemuth, P.M., Hubbert, K.R, and Robichaud, P.R., 2001, The effects of log erosion barriers on post-fire hydrologic response and sediment yield in small forested watersheds, southern California: Hydrological Processes, v. 15, p. 3,053-3,066.

Wright Water Engineers Inc., 2005, Florida Watershed post-fire rehabilitation project, section 319 grant report. Wright Water Engineers, Inc., Durango, CO. 